\title{
Buku Ajar \\ Pengantar Ilmu Komunikasi
}

Penulis:

Didik Hariyanto

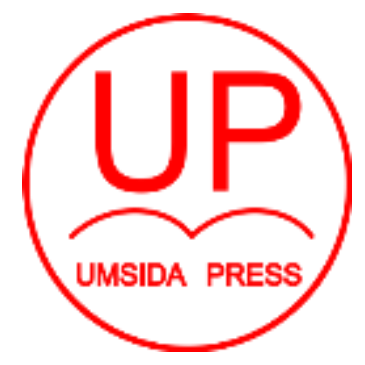

Diterbitkan oleh

UMSIDA PRESS

Jl. Mojopahit 666 B Sidoarjo

ISBN: 978-623-6081-32-7

Copyright@ 2021.

Authors

All rights reserved 
Buku Ajar

Pengantar Ilmu Komunikasi

Penulis :

Didik Hariyanto

ISBN :

978-623-6081-32-7

Editor :

Ferry Adi Darma

Djarot Meidi Utomo

Copy Editor :

Ainur Rokhmaniah

Design Sampul dan Tata Letak:

Muhammah Imron

Penerbit:

UMSIDA Press

\section{Redaksi :}

Universitas Muhammadiyah Sidoarjo

J1. Mojopahit No 666B

Sidoarjo, Jawa TImur

Cetakan pertama, Agustus 2021

(C) Hak cipta dilindungi undang-undang

Dilarang memperbanyak karya tulis ini dengan suatu apapun tanpa ijin tertulis dari penerbit. 


\section{KATA PENGANTAR}

Puji syukur Alhamdulillah buku ajar Pengantar Komunikasi ini dapat terselesaikan dengan baik. Terima kasih juga penulis sampaikan pada Universitas Muhammadiyah Sidoarjo yang telah mempercayakan tanggungjawab penyusunan buku ajar ini pada penulis melalui program Riset Dasar Institusi.

Buku ini disusun dalam situasi yang tidak biasa, yakni terjadinya wabah global Covid - 19 atau yang kita kenal sebagai virus corona. Penulis menyadari banyak keterbatasan dan tantangan dalam menulis buku ajar ini, ditengah menyusun buku ajar ini penulis terinfeksi virus covid - 19 sehingga memerlukan perawatan serius beberapa waktu lamanya. Namun dengan deadline yang tidak bisa di dikompromi penulis berusaha menyelesaikan buku ajar Pengantar Ilmu Komunikasi sesuai jadwal.

Buku ini menjadi sangat penting terutama bagi mahasiswa baru yang mengambil Program Studi Ilmu Komunikasi, karena berisi tentang dasar-dasar ilmu komunikasi seperti pengertian, fungsi dan tujuan komunikasi, unsur-unsur dan komponen komunikasi, proses komunikasi, model komunikasi serta bentuk-bentuk komunikasi.

Penulis sungguh menyadari jika buku ajar ini memiliki berbagai kekurangan. Oleh karenanya, kritik dan saran pembaca sangat penulis butuhkan sebagai uapaya perbaikan pada penulisan selanjutnya. Semoga buku ajar ini bermanfaat bagi mahasiswa dan pembaca dan menjadi sebuah amal ibadah bagi penulis.

Sidoarjo, 30 Maret 2021

Tim Penulis,

\section{Dr. Didik Hariyanto, S.S.os., M.Si}




\section{DAFTAR ISI}

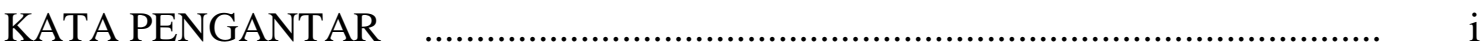

DAFTAR ISI

BAB I SEJARAH KOMUNIKASI DAN PENTINGNYA MEMPELAJARI KOMUNIKASI

1.1. Sejarah Kounikasi

1.2. Komunikasi Zaman Islam ....................................................... 3

1.3. Mengapa Ilmu Komunikasi Perlu Dipelajari ............................. 6

BAB II TINJAUAN TENTANG KOMUNIKASI DALAM KONTEKS PENGETAHUAN DAN ILMU

2.1. Perbedaan Pengetahuan dan Ilmu $\quad$........................................... 9

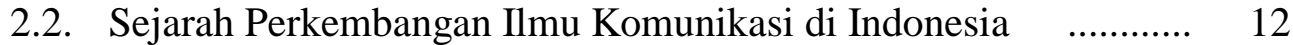

2.3. Publisistik vs Komunikasi ........................................................... 12

BAB III PENGERTIAN DAN DEFINISI KOMUNIKASI

3.1. Pengertiam Komunikasi .......................................................... 15

3.1.1.Pengertian Komunikasi Secara Umum ............................. 16

3.1.2. Pengertian Komunikasi Secara Paradigmatis $\quad$.................... 17

3.2. Definisi Komunikasi ........................................................... 18

3.2.1. Macam-Macam Definisi Komunikasi ............................. 19

3.2.2. Definisi Komunikasi Menurut Beberapa Pakar ................. 20

3.2.3. Definisi Komunikasi Menurut Beberapa Pakar $\quad$................ $\quad 20$

3.3. Konseptualisasi Komunikasi f................................................... 24

3.3.1. Komunikasi Sebagai Tindakan Satu Arah (John R. Wenburg, dkk) …........................................................ 24

3.3.2. Komunikasi Sebagai Interaksi (Wilbur Schramm dan Osgood) ................................................................ 26

3.3.3. Komunikasi Sebagai Transaksi f....................................... 26

BAB IV PROSES DAN KOMPONEN KOMUNIKASI

4.1. Preses Komunikasi ............................................................ 28

4.2. Proses Komunikasi Menurut Pakar …....................................... 29 
4.3. Unsur-Unsur Dalam Komunikasi ............................................ 32

4.4. Lingkungan Komunikasi ........................................................ 33

4.5. Efek Komunikasi ................................................................. 38

4.5.1. Jenis-Jenis Efek $\quad$........................................................... 39

4.5.2. Jenis-Jenis Feedback Menurut Nenurut Beberpa Pakar ..... 39

4.6. Etik dan Kebebasan Memilih ........................................................ 40

BAB V TUJUAN DAN FUNGSI KOMUNIKASI

5.1. Tujuan Komunikasi ................................................................ 43

5.2. Fungsi Komunikasi ….......................................................... 45

BAB VI KOMUNIKASI VERBAL DAN NON VERBAL

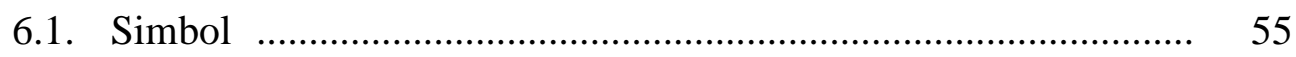

6.2. Komunikasi Verbal _........................................................... 57

6.3. Fungsi Bahasa Dalam Kehidupan Manusia ............................... 59

6.4. Komunikasi Non Verbal ............................................................. 60

\section{BAB VII KOMUNIKASI INTRA PRIBADI}

7.1. Tahapan-Tahapan Komunikasi Intra Pribadi .............................. 66

7.2. Faktor Yang Mempengaruhi Komunikasi Intrapersonal ............. 70

\section{BAB VIII KOMUNIKASI ANTAR PRIBADI}

8.1. Komunikasi Anata Pribadi ......................................................... 72

8.1.1.Pengertian Komunikasi Antarpribadi ............................... $\quad 72$

8.2. Persepsi Interpersonal ........................................................... 75

8.2.1. Konsep Diri ................................................................. 75

8.3. Atraksi Interpersonal ............................................................. 76

8.4. Komunikasi Kelompok ........................................................... 76

8.5. Karakteristik Komunikasi Kelompok ….................................... 78

8.6. Jaringan Komunikasi …........................................................ 79

\section{BAB IX KOMUNIKASI MASSA}

9.1. Definisi Komunikasi Massa .................................................. 81

9.2. Penyebaran Arus Anonym Komunikasi Massa Ada 4 Model .... 85

9.2.1. Model Jarum Hipodermik/Jarum Suntik/Peluru ............... 85

9.2.2. Model Komunikasi Satu Tahap ....................................... 85

9.2.3. Model Komunikasi Dua Tahap ......................................... 85

9.2.4. Model Komunikasi Multi Tahap .................................... 86

9.3. Perbedaan Komunikasi Massa \& Tatap Muka …....................... 87 
9.4. Proses \& Model Komunikasi Massa $\quad$............................................ 87

9.4.1. Komunikasi Primer …................................................... 87

9.4.2. Komunikasi Sekunder ........................................................ 88

9.4.3. Proses Komunikasi Massa …............................................. 88

9.5. Hambatan Dalam Komunikasi Massa ........................................ 88

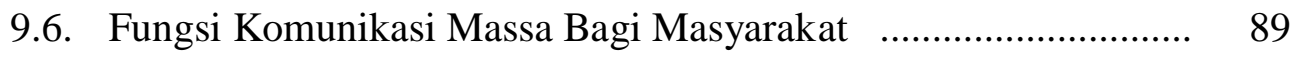

BAB X MODEL-MODEL KOMUNIKASI

10.1. Pengertian Model ….............................................................. 91

10.2. Fungsi dan Manfaat Model Komuniksi ..................................... 92

10.3. Model H Laswell ...................................................................... 93

10.4. Model Shannon dan Weaver (1949) ............................................ 95

10.5. Model Komunikasi Melvin de Fleur 1966 .................................. 97

10.6. Model Berlo (1960) ................................................................... 98

10.7. Model S-O-R (Stimulus Organism Respon), Houland ............... 99

10.8. Model Aristoteles ................................................................... 100

10.9. Model Komunikasi Wilbur Schramm ..................................... 101

10.10. Model Helical Dance ................................................................... 104

10.11. Model Seiler .......................................................................... 105

\section{BAB XI PRINSIP-PRINSIP KOMUNIKASI}

11.1 Komuniksi Mempunyai Dimensi Isi dan Hubungan ….............. 107

11.2. Komunikasi Itu Berlangsung Dalam Berbagai Tingkat

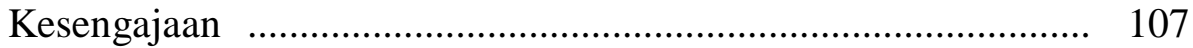

11.3. Komunikasi Terjadi Dalam Konteks Ruang dan Waktu ............ 108

11.4. Komunikasi Melibatkan Prediksi Peserta Komunikasi ............. 108

11.5. Komunikasi Itu Bersifat Sistemik .......................................... 108

11.6. Komunikasi Bersifat Nonsekuensial ...................................... 109

11.7. Komunikasi Bersifat Prosesual, Dinamis dan Transaksional ..... 109

11.8. Komunikasi Bersifat Irreversible .......................................... 109

11.9. Komunikasi Bukan Panasea Untuk Menyelesaikan Berbagai Masalah

Daftar Gambar:

Gambar 4.3: Proses Komunikasi Secara Universal Lawrence Kincaid (1981).................... 33

Gambar 4.4: Inferential Feedback ............................................................................ 40 
Gambar 7.1: Komunikasi Kelompok Beebe dan Masterson, 1982

Gambar 9.1: Model Komunikasi Multi Tahap .................................................. 86

Gambar 10.1: Model KomunikasiLasswell ..................................................................... 93

Gambar 10.2 : Model Komunikasi Shannon dan Weaver ................................................... 95

Gambar 10.3: Model Komunikasi Melvin DeFleur........................................................... 97

Gambar 10.4: Model Komunukasi Berlo (1960) ….......................................................... 99

Gambar. 10.5: Model Komunikasi S-R ............................................................... 100

Gambar. 10.6: Model Komunikasi Aristoteles ............................................................. 101

Gambar. 10.6: Model Komunikasi Wilbur Schramm .................................................. 102

Gambar 10.6. Model komunikasi sirkular dari Osgood \& Schramm ............................... 104

Gambar 10.6. Model komunikasi Dua Arah ( Seiler,1988 ) ............................................. 105 


\section{BAB I}

\section{Sejarah Komunikasi Dan Pentingnya Mempelajari \\ Ilmu Komunikasi}

\section{TUJUAN INSTRUKSIONAL UMUM}

Setelah menyelesaikan materi Bab 1 ini mahasiswa diharapkan mampu:

1. Memahami sejarah ilmu komunikasi dan perkembangannya

2. Memahami arti penting dari ilmu komunikasi

3. Memahami tujuan mempelajari ilmu komunikasi

\section{TUJUAN INSTRUKSIONAL KHUSUS}

Setelah mempelajari materi Bab 1 ini mahasiswa diharpkan mampu:

1. Menjelaskan tentang sejarah ilmu komunikasi

2. Menjelaskan arti penting ilmu komunikasi

3. Mendiskusikan perkembangan ilmu komunikasi dan manfaatnya

\subsection{SEJARAH KOMUNIKASI}

Sejarah komunikasi di mulai dengan perkembangan aktifitas retorika yang terjadi di zaman Yunani kuno. Komunikasi baru mulai berkembang ketika ditemukan mesin cetak oleh Guttenberg (1457). Ada perbedaan rentang waktu pencatatan sejarah antara hasil pemikiran ahli sejarah komunikasi pada abad 19 dengan pencatatan sejarah zaman Yunani kuno. Sejarah perkembangan ilmu komunikasi itu sendiri terputus kirakira 1400 tahun. Dimulai saat aktifitas retorika awal sampai pada abad pertengahan (saat penyebaran agama). Artinya perkembangan ilmu komunikasi tidak mengalami rantai yang terputus. Zaman pertengahan menjadi penyambung ilmu komunikasi dari zaman yunani kuno ke zaman renaissance, modern dan kontemporer.

Pada saat zaman Romawi perkembangan komunikasi tidak berlangsung mulus, karena Romawi pada saat itu mengalami masa kegelapan (dark ages). Padahal, masa kegelapan yang terjadi di Eropa ini merupakan sisi lain dari masa keemasan peradaban 
Islam, dimana pada masa ini perkembangan ilmu pengetahuan (termasuk aktifitas komunikasi) cukup signifikan. Selain di Eropa perkembangan komunikasi juga berkembang di Cina. Perkembangan komunikasi di Cina telah dimulai pada tahun 550 SM. Memang, aktifitas komunikasi dalam bentuk retorika yang berlangsung di Cina dan Islam ini lebih menekankan pada penyebaran ajaran dan keyakinan. Berbeda dengan di Yunani dan Romawi yang lebih bersifat politis. Salah satu ajaran yang berkembang yaitu ajaran konfusiunisme di Cina. Kong hu $\mathrm{Cu}$ (bagian dari konfusianisme) lahir pada sekitar 550 SM yang ajarannya telah berusia 2000 tahun. Konfusius mulai mengajarkan filsafat hidupnya ketika Cina masih terpecah-pecah. Penyebaran komunikasi di Cina mulai mengalami perkembangan saat ditemukannya kertas oleh Ts'ai Lun (105 M). Namun, ketika dinasti Qin (215 SM-206 SM), kaisar Qin Shi Hung melarang ajaran Konfusianisme, sehingga banyak buku-buku yang dibakar. Namun, ketika masa dinasti Han (206 SM-220 M), konfusianisme mulai mencapai masa emasnya kembali. Misalnya dengan didirikannya semacam Imperial University yang meninggalkan kitab-kitab ajaran konfusianisme seperti kitab Shi Ching (kumpulan lagu-lagu), Shu Ching (dokumen-dokumen), I Ching (buku ahli ramalan), Ch'un Ch'iu (peristiwa penting), dan Li Chi (upacara-upacara). Konfusianisme ini berlangsung cukup lama sampai pada masa jatuhnya dinasti Ching (1644-1911). Hal ini mengidentifikasikan bahwa adanya proses perkembangan komunikasi yang lebih condong pada penyebaran ajaran-ajaran konfusianisme di Cina.

Aktifitas komunikasi dalam bentuk propaganda juga telah ada di zaman Isa Almasih. Isa yang pada waktu itu ingin mengajarkan ajaran Allah, mendapat tantangan dari kaum Yahudi. Isa dianggap bahaya oleh kaum Yahudi, sehingga orang-orang Yahudi berusaha memancing kemarahan pihak penguasa Romawi yang ketika itu menguasai Palestina. Akhirnya usaha ini berhasil mempengaruhi sikap politik penguasa Romawi yang pada awalnya tidak ikut campur dalam keagamaan, kini berubah haluan memerintahkan tentaranya untuk menangkap Isa dan menghukum Isa $\mathrm{Al}$ Masih. Namun, catatan sejarah menunjukkan bahwa sebenarnya Isa tidak mati terkutuk di tiang salib, ia berhasil diselamatkan oleh Pilatus yang telah bekerjasama dengan yusuf Aritmatea (Injil Yahya, 19:38). Setelah memperlihatkan bukti-bukti kepada muridnya bahwa beliau tidak mati di kayu salib (Injil Markus, 16:19-20), maka Al Masih memutuskan atas perintah Allah untuk meninggalkan Palestina dan menjelajahi berbagai negeri dimana berdiam suku-suku Israil yang hilang untuk melanjutkan menyampaikan risalahNya (berdakwah) (kitab Ester 3:6, 1:1, 2:6, dan II Raja-raja 
15:29). Negeri terakhir dimana tempat peristirahatan beliau adalah Srinagar, India. Komunikasi dalam bentuk ajaran dakwah yang dilakukan di zaman Isa ini terbukti dengan adanya penjelasan Dalai Lama (pendeta Budhah Tibet) bahwa Isa adalah salah satu orang suci yang dihormati dalam ajaran Budhah. Hal ini berkaitan erat dengan kepercayaan Budha yang mengatakan bahwa Baghawa Metteya (pengembara kulit putih; Isa Al Masih) pernah datang mengajarkan ajarannya di India. Juga dengan diketemukannya scroll (gulungan yang jumlahnya 84.000 gulungan) yang isinya menceritakan aktifitas penyebaran ajaran Isa di India. Bukti lain juga dengan ditemukannya kuburan Yus Asaf di Srinagar, Kashmir oleh tim Jerman Barat yang merupakan kuburan nabi Isa yang meninggal pada usia 120 tahun. (Thre Tribune, Chandigarh, 11 Mei 1984).

\subsection{KOMUNIKASI ZAMAN ISLAM}

Komunikasi dalam Islam sebenarnya sudah dimulai semenjak Allah memutuskan untuk menunjuk khalifah di muka bumi ini dan yang akan membangun peradaban di muka bumi ini. Seperti Firman Allah "Dan (ingatlah) ketika Tuhannmu berfirman kepada para malaikat, "Aku hendak menjadikan khalifah di bumi."Mereka berkata, "Apakah Engkau hendak menjadikan orang yang merusak dan menumpahkan darah di sana, sedangkan kami bertasbih memuji-Mu dan menyucikan nama-Mu" Dia berfirman," Sungguh, Aku mengetahui apa yang tidak kamu ketahui. "Dan Dia ajarkan kepada Adam nama-nama (benda) semuanya, kemudian Dia perlihatkan kepada para malaikat, seraya berfirman "Sebutkan kepada-Ku nama semua (benda) ini, jika kamu yang benar!" (al-Baqarah/2:30-31)

Pada ayat di atas sudah ada dialog atau komunikasi antara Allah dengan Malaikat ketika memutuskan untuk menciptaka manusia sebagai khalifah di bumi. Menurut Tahir Ibnu Asyur, penyampaian keputusan Allah itu untuk mendorong agar para malaikat bertanya sehingga - dengan pola komunikasi tanya jawab yang dialogis itu - para malaikat menjadi tercerahkan mengenai keutamaan dan keunikan jenis manusia yang akan dicptakan-Nya sebagai khalifah di muka bumi. Ibnu Asyur dalam Tafsir Maudhu'i (4:2019). Menurut Asyur ayat ini banyak dipahami oleh mufasir sebagai semacam permintaan pendapat (istisyarah) sehingga dapat menjadi sebuah model pengajaran yang bersifat interaktif-komunikatif, seperti halnya guru menganjar muridnya dalam bentuk tanya jawab. 
Banyak pula pendapat para ahli yang mendifinisikan komunikasi itu sebagai berbicara, ya ilmu tentang berbicara. Semua manusia itu pasti berkomunikasi dalam berinteraksi, meskipun komunikasi tidak semua dilakukan dengan berbicara tetapi dapat juga dilakukan dengan beberapa simbol-simbol selain berbicara. Seperti firman Allah dalam Al-Quran surah ar-Rahman/55:1-4. " (Allah) Yang Maha Pengasih, Yang telah mengajarkan Al-Qur'an. Dia menciptakan manusia, mengajarnya pandai berbicara. (ar-Rahman/55:1-4).

Namun menurut M.Quraish Shihab, berbicara (al-bayan) di sini tidak hanya terbatas pada kemampuan berbicara atau berucap (kalam) baik oral maupun tulisan saja, termasuk mencakup juga segala bentuk ekspresi termasuk seni dan raut muka, isyarat/sinyal dan jenis-jenis ekspresi/komunikasi non-verbal lainnya. Dengan potensi al-bayan ini manusia kemudian dapat berkomunikasi dan berinteraksi dengan lainnya sebagai makhluk sosial, Sihab dalam Tafsir Maudhu'i (6:2019). Jadi komunikasi sudah ada sebelum manusia turun ke bumi ini, kemudian dilanjutkan oleh Nabi Adam sebagai khalifah di muka bumi ini. Dengan komunikasi ini pula manusia melakukan interaksinya dalam kehidupan bermasyarakat sebagai makhluk sosial di muka bumi ini.

Pada masa berikutnya perkembangan komunikasi di dunia Islam pun sebenarnya telah mengalami perkembangan yang cukup signifikan. Seperti yang terjadi pada saat zaman Isa Al Masih, komunikasi Islam pun lebih berorientasi pada sistem dakwah yang berusaha mengubah atau mempengaruhi alam pikiran seseorang untuk mengikuti syariat Islam. Peradaban umat Islam dalam kaitannya dengan perkembangan komunikasi telah mencatatkan sejarah yang cukup menakjubkan. Pada masa bani Umayah misalnya, telah ditemukannya suatu cara pengamatan astronomi pada abad 7 M, 8 abad sebelum Galileo Galilei dan Copernicus. Perhubungan antara Timur dan Barat selama perang Salib (1100-1300 M) sangat penting untuk perkembangan komunikasi ilmu pengetahuan di Eropa. Karena pada waktu ekspansi, Arab telah mengambil alih kebudayaan Byzantium, Persia, dan Spanyol, sehingga tingkat kebudayaan Islam jauh lebih tinggi dari pada kebudayaan Eropah (Brower, 1982;41). Universitas Bagdad, Damsyik, Beirut, dan Kairo menyimpan dan memberikan warisan ilmiah dari India, Persia, Yunani, dan Byzantium, sehingga Eropa menerima warisan filsafat Yunani melalui orang Arab yang terlebih dahulu mempelajarinya. Karena bangsa Arab telah menterjemahkan karyakarya fisuf termasyur seperti Plato, Hipokrates dan Aristoteles. Sekitar abad ke-14 pada zaman dinasti Yuan (1260-1368), pengaruh Islam ditandai dengan peneliti di bidang astronomi pertama yang mendirikan observatorium, yaitu Jamal Al-Din. 
Perkembangan komunikasi dalam Islam yang lebih bersifat dakwah tadi tidak lepas dari kaitannya sebagai bagian dari bentuk komunikasi, karena dalam bahasa arab, dakwah berarti seruan, panggilan, atau ajakan. Tugas utama para rasul adalah menyampaikan risalah/misi Tuhan kepada manusia (tablig). Para rasul adalah muballigh (komunikator) menyampaikan semua wahyu Allah SWT. Dalam Al-Qur'an peran rasul sebagai balag ini disebut sebanyak 15 kali dalam 13 surah yang berbeda. Tafsir Maudhu'i (8:2019).

Menurut Salahuddin Sanusi, yang didefinisikan oleh Al Ustadz Bahiyul Khuli dalam bukunya yang berjudul Tadzkiratud Du'at, dalam proses dakwah telah terjadi proses interaksi antar individu maupun kelompok manusia yang bertujuan untuk mengubah tatanan dari jaman kebodohan (zaman jahiliyah) menuju zaman pencerahan dengan ajaran agama Islam. Nabi Muhammad SAW menyebarkan agama Islam dalam waktu singkat (570 M-632 M), penyebaran Islam berlangsung dalam waktu yang relatif singkat (8-9 M). Dalam waktu 25 tahun, Nabi Muhammad beserta pengikutnya (yang disebut sebagai Muslim), mengambil alih kekuasaan di kawasan Arab, dan Islam kemudian berkembang dengan sangat pesatnya. Pada sekitar tahun $650 \mathrm{M}$, Arab, seluruh daerah timur tengah, serta Mesir dikendalikan oleh orang-orang Islam, dan pada tahun 700 M, Islam mendominasi area besar mulai dari daratan China dan India di timur sampai Afrika Utara dan Spanyol di barat. Cepatnya perkembangan Islam bisa jadi merupakan dampak dari penggunaan dakwah-dakwah yang berisi tentang ajaran-ajaran Islam, seperti dakwah yang berisi tentang jihad fisabilillah, yaitu jaminan untuk masuk surga bagi mereka yang mati dalam usahanya untuk memperjuangkan Islam. Artinya terdapat bentuk komunikasi yang efektif sehingga dapat mempengaruhi keyakinan jutaan umat dalam waktu yang sangat singkat.

Dimasa nabi Muhammad SAW, komunikasi di awali dengan adanya perintah dari Allah kepada Nabi Muhammad untuk memberikan peringatan (dalam hal ini berdakwah) kepada ummat manusia untuk percaya kepada Allah. Awalnya komunikasi itu dilakukan secara diam-diam melalui komunikasi interpersonal lalu dilanjutkan secara terbuka seiring dari wahyu berikutnya yang memerintahkan Nabi untuk berdakwah secara terang-terangan (Q.S Al-Hijr; 94-95).

Dalam media tulisan, sebenarnya telah dirintis oleh Rasulullah, yaitu ketika beliau mengirimkan surat yang isinya ajakan untuk memeluk Islam kepada para raja di Eropa. Sebagai contoh, nabi pernah mengirimkan surat dakwah kepada raja Hiraqla (raja di Roma Timur) yang bernama Hirakles, raja Habsyi yang bernama Najsyi, dan 
lain-lain. Dalam setiap suratnya, selalu dibubuhi stempel yang terbuat dari perak yang berukirkan tulisan "Muhammadurrasulullah". Dengan contoh ini, maka Rasulullah telah merintis sistem jurnalistik dalam melakukan komunikasi Islam sebagai bentuk dakwah. Dalam perkembangannya, komunikasi telah sedemikian maju, contoh lain dalam hal diskusi yang merupakan bagian dari bentuk komunikasi kelompok.

Dalam berdakwah, Rasulullah selalu melakukan komunikasi yang santun dan penuh kasih sayang. Keberhasilan dakwa Rasulullah dilandaskan pada alasan yang kuat (hujjah), tutur kata yang arif dan bijak (uslub), dan adab sopan santun yang baik.

Sejarah perkembangan komunikasi sebenarnya tidak pernah terputus. Karena pada dasarnya hubungan antara komunikasi sebagai bagian dari perkembangan peradaban manusia begitu erat. Hal ini dikarenakan aktifitas retorika sudah ada di zaman pertengahan, tetapi memang belum berbentuk ilmu. Fenomena yang lebih banyak bersifat dakwah (penyebaran agama) ini baru berupa gejala-gejala sosial, dan pada masa itu belum ada suatu ilmu yang mengkhususkan fokus dan lokus kajiannya tentang komunikasi. Tetapi setidaknya hal di atas cukup memberikan argumen bahwa komunikasi merupakan fenomena yang sudah sangat lama terjadi dan baru dikaji secara utuh sebagai suatu ilmu pada abad ke-19 di daratan Amerika.

\subsection{MENGAPA ILMU KOMUNIKASI PERLU DIPELAJARI}

Ketika pertama penulis mengajar kelas mata kuliah Pengantar Ilmu Komunikasi, selalu di awali dengan bertanya kepada mahasiswa baru, "Mengapa anda mengambil jurusan ilmu komunikasi?, Apa yang ingin anda pelajari di jurusan ilmu komunikasi? Komunikasi itu untuk apa?” Bisa ditebak, jawabannya sangat beragam;

Komunikasi adalah fungsi sosial dari makhluk hidup yang bernama manusia. Sebagai makhluk sosial manusia tidak akan tidak berinteraksi dengan manusia yang lain. Dalam berinteraksi, manusia membutuhkan komunikasi sebagai sarananya baik secara personal maupun kelompok, karena manusia pasti selalu memerlukan orang lain. Dengan demikian, perilaku interaksi sosial yang dilakukan oleh manusia tumbuh secara alamiah sesuai dengan fitrah kebutuhan manusia.

Islam mengenal dengan istilah ta'ruf, konsep saling mengenal yang tidak membedakan suku, ras, bahasa, kebudayaan, bahkan keyakinan sekalipun. Dalam perspektif Islam, komunikasi disamping untuk menjalin hubungan horizontal terhadap sesama manusia (hablum minannas) juga digunakan untuk hubungan vertikal kepada Allah (hablum minallah). Hubungan vertikal diwujudkan dalam bentuk ibadah seperti berdo'a, sholat, puasa dan lain-lain yang bertujuan membentuk ketaqwaan. 
Komunikasi dengan sesama manusia sebagai wujud dari hubungan sosial atau mu'amalah ijtima'iyyah yang tercantum dalam segala aspek kehidupan manusia, seperti agama, politik, budaya, ekonomi dan seni. Dakwah, tabligh, ceramah, khutbah dan majlis taklim adalah bentuk-bentuk komunikasi dan informasi dengan segala metode dan teknik untuk menginformasikan ajaran Islam.

Komunikasi diwujudkan dalam bentuk penyampaian pesan-pesan baik verbal maupun non verbal dalam mengaktulisasikan diriya dalam hal ide, perasaan, keterampilan melalui penggunaan simbol kata-kata, gambar, angka dan tulisan yang itu disebut komunikasi oleh Barelson dan Steiner.

Komunikasi antar manusia merupakan suatu rangkain proses yang halus dan sederhana, walau demikian komunikasi antar manusia selalu dipenuhi oleh berbagai unsur sinyal, sandi dan arti. Ilmu komunikasi dipelajari setidaknya karena tiga alasan, pertama manusia sebagai mahluk sosial senantiasa ingin berhubungan dengan orang lain. Tidak ada manusia yang normal tidak betriteraksi dengan manusia yang lain dalam hubungan bermasyarakat paling tidak interaksi itu berupa komunikasi dengan sesama. Kedua, Komunikasi merupakan bagian kekal dari kehidupan manusia seperti halnya bernafas. Sepanjang manusia ingin hidup maka ia perlu berkomunikasi (Everett Kleinjan - Hawaii). Ketiga, Komunikasi merupakan kebutuhan yang sangat fundamental bagi seseorang dalam bermasyarakat. Komunikasi dan masyarakat adalah dua kata kembar yang tidak dapat dipisahkan.Tanpa komunikasi tidak mungkin masyarakat terbentuk, sebaliknya tanpa masyarakat, maka manusia tidak mungkin dapat mengembangkan komunikasi (Schramm, 1982).

Komunikasi juga bisa berdampak pada keberhasilan dan kegagalan seseorang dalam mencapai tujuan hidup, karir serta cita-cita dan harapan-harapan yang diinginkan.Termasuk gejala-gejala masyarakat informasi saat ini semakin nampak perwujudannya, ditandai dengan makin banyaknya orang memilih profesi pada sektor informasi, misal Communication Consultants, Communication Manager, Propagandist, Researchers, Writers, Pers, counsutan communication Public Relations Officers, Advertiser, Sales Promotion, Presenter, Broadcast Programmer dan Production House. Selain itu kemajuan teknologi komunikasi berlangsung dari waktu ke waktu begitu cepat, ini telah memberi pengaruh terhadap cara-cara manusia berkomunikasi. Pesatnya perkembangan dunia teknologi dan informasi dengan akses internet, hal ini menjadikan perubahan komunikasi konvensional menjadi modern dan serba digital. Ditunjang oleh kecanggihan 
Smartphone telah memberikan fasilitas yang beraneka ragam mulai dani SMS, MMS, Chating, Email, Browsing dan fasilitas media sosial (WhatsApp, Facebook, Instagram dan lainnya). Untuk itu sangat diperlukan kemampuan penguasaan teknologi komunikasi dan metode pembelajarannya yang bertujuan untuk mengetahui cara-cara yang efektif dalam berkomunikasi, itulah mengapa komunikasi perlu dipelajari.

\section{Referensi}

Djoenasih. Pengantar Ilmu Komunikasi Jilid 1. Leberty Yogyakarta. 1990

DevitoA.Joseph. Komunikasi antar manusia, edisi kelima terjemah. Hunter College of the city University of New York

Tim Lajnah Pentashihan Mushaf Al-Qur'an, Tafsir Al Maudh 'i (Tafsir Al Qur'an

Tematik) Komunikasi dan informasi.Lentera Ilmu Makrifat. 2019

Vardiansyah. Pengantar Ilmu Komunikasi. Ghalia Indonesia. 2004

John Fiske. Pengantar Ilmu Komunikasi. PT. Raja Grafindo Persada 2012

https://defickry.com/2007/08/09/zaman-pertengahan-sebagai-bagian

Yulianita, Modul Pembelajaran Mata Kuliah Pengantar Komunikasi. 2008. Surabaya

https://scholar.google.co.id/scholar?q=Brower,+1982\%3B41\&hl=en\&as_sdt=0\&as_vis

$=1 \&$ oi=scholart 


\section{BAB II \\ Tinjauan Tentang Komunikasi Dalam Konteks Pengetahuan Dan Ilmu}

\section{TUJUAN INSTRUKSIONAL UMUM}

Setelah menyelesaikan materi Bab 2 ini mahasiswa diharapkan mampu:

1. Memahami komunikasi sebagai pengetahuan

2. Memahami komunikasi sebagai Ilmu

3. Memahami konsep dasar komunikasi sebagai ilmu

\section{TUJUAN INSTRUKSIONAL KHUSUS}

Setelah mempelajari Bab 2 ini mahasiswa diharapkan mampu:

1. Menjelaskan konsep pengetahuan dan ilmu

2. Menjelaskan ciri-ciri ilmu dan pengetahuan

3. Mendiskusikan perkembangan ilmu komunikasi dan risetnya

\subsection{PERBEDAAN PENGETAHUAN DAN ILMU}

Komunikasi merupakan aplied science atau ilmu terapan. Ilmu yang membidangi komunikasi adalah ilmu-ilmu sosial dasar (basic social sciences). Ada empat ilmu sosial dasar yang mendasarinya, diantaranya sosilogi, antropologi, psikologi dan psikologi sosial. Santoso (6:2008). Empat ilmu ini merupakan dasar dari terbentuknya ilmu komunikasi, karena itu komunikasi disebut dengan ilmu terapan artinya komunikasi merupakan terapan dari keempat ilmu tersebut.

Sebelum menguraikan bahwa komunikasi itu digolongkan sebagai ilmu, maka perlu dibedakan antara pengetahuan (knowledge) dan ilmu pengetahuan selanjutnya disebut ilmu (science). Bagaimana dengan komunikasi apakah digolongkan kedalam pengetahuan atau ilmu pengetahuan? Di bawah ini akan dijelaskan perbedaan antara pengetahuan dan ilmu pengetahuan.

Menurut Mohammad Hatta dalam bukunya Pengantar ke jalan ilmu dan pengetahuan yang dikutip oleh Djoenaesih membagi pengetahuan menjadi dua yaitu 
pengetahuan yang didapat dari pengalaman dan pengetahuan yang didapat dari keterangan. Pengetahuan yang didapat dari pengalaman derajat kebenarannya tergantung pada benar atau khilafnya penglihatan kita, sedangkan pengetahuan yang didapat dari keterangan memberi dasar yang kokoh akan pengetahuan kita, di sini kita mencari kebenaran dengan akal dan pikiran kita. Pengetahuan yang didapat dari pengalaman disebut pengetahuan (knowledge) sedangkan pengetahuan yang didapat dari keterangan disebut "Ilmu (science), Hatta dalam Djoenaesih (Djoenaesih 1991:29). Ilmu bersendi pada pengetahuan, sedangkan pengetahuan adalah tangga yang pertama bagi ilmu untuk memberi keterangan lebih lanjut. Pengetahuan dapat diketahui dengan menggunakan akal sehat. Contoh pengetahuan misalnya informasi kita dapatkan dari media massa, pengalaman pribadi (personal experience) atau mitos-mitos (myth). Beberapa kelemahan dari pengetahuan, adalah sifatnya yang pribadi, tidak bisa berlaku umum atau untuk orang banyak, biasanya berupa mitos-mitos, kebiasaan yang dipahami dengan akal sehat (common sense). Inilah kekurangan pengetahuan jika dijadikan sebagai sandaran berpikir.

Komunikasi sebagai fenomena ilmu pengetahuan telah muncul diawal abad 20, melalui kelompok Chicago yang berpusat di Universitas Colombia kemudian disebut sebagai administrative research. Figure penting dalam kelompok ini dalam mengembangkan ilmu komunikasi adalah Paul F. Lazarfeld. Kajian yang sangat dominan pada periode ini adalah kajian tentang propaganda. Ada juga kelompok yang berpendapat bahwa kajian komunikasi awalnya lebih dikenal dengan retorika (speech) dan jurnalistik, (Ruben). Selain Lazarfeld ada juga tokoh penting dalam proses pelembagaan ilmu komunikasi yaitu Wilbur Schramm.

Ciri lain dari Ilmu Pengetahuan adalah mempunyai sifat sistematis, mempunyai metode dan secara ilmiah dapat dipertanggungjawabkan. Sistematis karena ilmu pengetahuan tertata dan tersusun sebagaimana paradigma/perspektif teori. Ilmu pengetahuan juga bersifat obyektif berlaku universal, empiris dan dapat direplikasi. Berbeda dengan Aliran Humanistik yang berpandangan bahwa ilmu pengetahuan mempunyai sifat subjektif dengan gambaran fenomena tertentu yang unik dan tidak bersifat universal namun lebih fokus pada subjek yang dikaji. Aliran Ilmu Sosial eksakta juga menggunakan pendekatan humanistis dalam meneliti perilaku manusia.

Sedangkan Elwood Murray menyatakan bahwa ilmu harus mempunyai persyaratan diantaranya adalah: ruang lingkup, metodologi, teori, kritik dan penerapan 
atau aplikasi. Dengan menggunakan standar Murray, bagaimana dengan ilmu komunikasi apakah memiliki mpersyaratan sebagai ilmu?, berikut penjabarannya:

- Ruang lingkup ilmu komunikasi adalah manusia karena ilmu komunikasi tergolong ilmu-ilmu sosial yang mempelajari tentang manusia. Dengan demikian ketetapan-katetapannya tidak sama dengan hukum-hukum alam karena bersifat relatif kurang pasti.

- Metodologi Riset, seperti metode content analysis (Harold D. Lasswell), Pendekatan eksperimen oleh Carl Hovland yang meneliti mengenai komunikasi persuasif, Propaganda oleh Bernard Berelson, survey oleh Paul F. Lazarfeld, Elihu Katz, (uses \& gratification, agenda setting, cultivation analysist dan sebagainya). John Fiske memberikan metode lain dalam penelitian komunikasi yaitu dengan pendekatan interpretatif. Beberapa pendekatan interpretatif seperti pendekatan semiotik, ethnografi, framing, dan discourse analysis. Penelitian dengan tema media dan budaya juga sudah banyak dilakukan oleh para peneliti bidang ilmu komunikasi. Seperti penelitian Ien Ang dengan karyanya yang terkenal Watching Dallas dengan pendekatan etnografi dan semiotik, subyek penelitiannya adalah penonton Dallas. Penelitian dengan pendekatan etnografi komunikasi dilakukan oleh James Lull dengan subyek penelitiannya adalah penonton televisi. Dari paparan di atas dapat menjelaskan bahwa komunikasi memenuhi kriteria sebagai ilmu pengetahuan, terutama yang berkaitan dengan metode penelitiannya. Dari situ tampak bahwa komunikasi sebagai fenomena ilmu pengetahuan dapat diterima sebagaimana dapat dibuktikan dengan munculnya jurnal komunikasi, hasil penelitian komunikasi, dan buku-buku komunikasi.

- Teori Komunikasi, Ilmu komunikasi juga mempunyai teori-teori yang banyak dikemukakan oleh pakar-pakar komunikasi karena komunikasi itu bersifat konkrit bukannya abstrak. Teori komunikasi juga mempunyai periodesasi dari klasik sampai post modern saat ini. Diantara teori-teori komunikasi antara lain, uses \& gratification, agenda setting, cultivation analysist, survay, eksperimen dll.

- Kritik, Ilmu komunikasi juga mempunyai kritik, terbukti setiap muncul suatu paradigma baru tentang komunikasi selalu ada kritik dari paradigma lain.Ilmu komunikasi selalu dinamis dalam perkembangannya tidak statis.Tidak menganut kemapanan teori.Ilmu komunikasi selalu dikaitkan dengan perkembangan teknologi informasi yang ada. 
- Penerapan atau Aplikasi, Ilmu komunikasi mempunyai aplikasi yang luas dalam kehidupan, ini bisa dilihat dari semakin berkembangnya spisialisasi dari ilmu komunikasi seperti jurnalistik, publik relations, advertasing (periklanan), publisistik, propaganda, event organazing.

Dari beberapa sarat-sarat yang dikemukakan oleh Elwood Murray tersebut maka jelaslah bahwa komunikasi dapat digolongkan menjadi ilmu pengetahuan bukan hanya sekedar pengetahuan atau (knowledge).

\subsection{SEJARAH PERKEMBANGAN ILMU KOMUNIKASI DI INDONESIA}

Sejarah Ilmu Komunikasi di Indonesia dimulai sejak akhir tahun 1950-an, ketika itu ilmu komunikasi masuk dari negara Jerman (Antoni, 2004). Awal nya Ilmu Komunikasi di Indonesia hanya fokus pada kajian publisistik atau ilmu informasi publik. Ilmu komunikasi di ajarkan pertama kali di Universitas Gajah Mada (UGM) pada tahun 1948 dengan nama Ilmu Penerangan. Pada tahun 1955 UGM mendirikan jurusan publisistik, dan pada tahun 1953 Perguruan Tinggi Jurnalistik Jakarta juga berubah menjadi Sekolah Tinggi Publisistik.

Pendidikan tinggi publisistik di Indonesia mulai berkembang pada dekade 1960- an dan 1970-an dengan dibentuknya Jurusan Publisistik pada sejumlah perguruan tinggi negeri seperti UI (1959), Unhas (1960), Unpad (1964), Undip (1967), serta beberapa perguruan tinggi swasta PTS di Indonesia. Pada tahun 1974, Prof. Dr. Astrid Susanto Sunario yang ketika itu Dekan Fakultas Publisistik Unpad mewacanakan tentang pandangan Schelsk bahwa komunikasi lebih luas daripada publisistik.

\subsection{PUBLISISTIK VS KOMUNIKASI}

Istilah publisistik awalnya berasal dari bahasa Jerman Publizistik yang diambil dari bahasa latin publicare artinya mengumumkan, memberitahukan, ataupun menyebarkan. Jika dilihat dari etimologi atau asal katanya maka kegiatan publisistik merupakan kegiatan seorang atau sekelompok orang dan yang erat korelasinya dengan masyarakat. Jadi kalau ada pembicaraan antara dua individu yang sedang kasmaran maka itu tidak termasuk kegiatan publisistik. Beberapa tokoh publisistik seperti Corax, Plato, Aristoteles, Ciciro dan Demosthenes selain filsuf mereka merupakan orang yang akhli dalam publisistik. Karena yang mereka utarakan selalu berkaitan dengan masalah kenegaraan dan kemasyarakatan. 
Publisistik sebenarnya lebih mengarah kepada kegiatan pesurat-kabaran atau jurnalistik saat ini. Ada dua pendapat terkait publisistik atau persurat-kabaran ini, pertama ada yang menganggap itu sebuah pengetahuan (kunde) atau zaitungskunde. Pendapat ke dua menganggap persurat-kabaran merupakan ilmu pengetahuan catau zeitungswissenchaft atau ilmu persurat-kabaran.

Publisistik pertama kali masuk ke Indonesia di bawah oleh sarjana-sarjana Indonesia yang belajar di Jerman saat itu. Mereka kemudian memperkenalkan publisistik menjadi salah satu ilmu baru di Indonesia. Salah satu tokohnya adalah Djamaludin Adinegoro. Menurut Adinegoro publisistik adalah ilmu pernyataan antar manusia yang umum dan aktual serta melakukan penelitian secara ilmiah pengaruh mulai proses sampai dampaknya terhadap khalayak atau komunikan.

Menurut Djoenaisih pengertian Adinegoro tentang publisistik ini sama dengan pengertian komunikasa massa (mass communication) di Amerika Serikat dan juga mirip dengan difinisi yang diberikan oleh Walter Hagemann. Namun banyak juga yang mengaangap difinisi Walter Hagemann ini terlalu sempit yang hanya fokus pada pernyataan manusia secara sadar tidak memuat pernyataan yang tidak sadar.

Sedangkan sejarah perkembangan komunikasi diawali oleh istilah journalism yang disampaikan oleh Joseph Pulitzer dari Amerika Serikat yang merupakan pendiri dari pendidikan Journalistik (school of journalistik). Di samping Pulitzer ada juga tokoh William Randolph Hearts yang terkenal dengan tulisan berita sensasinya sehingga surat kabar yang dipimpinnya digelari Yellow Journalism atau Yellow Pers.

Perbedaan antara publisistik di Jerman dengan jurnalistik di Amerika Serikat adalah " di Jerman pada mulanya publisistik di kembangkan oleh kaum ilmuan dan kemudian dilanjudkan oleh para praktisi, sedangkan di Amerika Serikat journalistik awalnya di kembangkan oleh kaum praktisi dan dilanjutkan oleh para sarjana.

Di Amerika Serikat komunikasi banyak dikembangkan oleh ahli-ahli Psikologi Sosial, sedangkan di Jerman Publisistik banyak dikembangkan dan dipelajari oleh ahliahli Sosiologi Sosial. Perkembangan radio pada th 1920, film dan telivisi pada tahun 1948, maka obyek jurnalistik di Amerika tidak hanya pers (surat kabar) saja, tetapi berkembang juga pada pers radio, film dan televisi yang kemudian berkembang menjadi Mass Communication atau komunikasi massa. Karena makin meluasnya cakupan yang dipelajari, kemudian Mass Comunication berubah menjadi Comunication Science atau ilmu komunikasi. 
Beberapa figure bidang ilmu komunikasi di Indonesia seperti M. Alwi Dahlan, Astrid Susanto Sunario, Andi Muis, Jalaludin Rahmat, Ashadi Siregar, Anwar Arifin, Hafid Changara, Dedy N. Hidayat, Marwah Daud Ibrahim, Onong Efendi Uchayana, dan sebagainya. Figure-figure inilah yang mewarnai khazanah perkembangan ilmu komunikasi di Indonesia.

\section{Referensi}

Berger, Roloff, Ewoldsen, Handbook Ilmu Komunikasi. Terjemah, Nusa Media 2014

CANGARA. H. Pengantar Ilmu Komunikasi.PT RajaGrafido Persada.Depok 2000

Djoenasih. Pengantar Ilmu Komunikasi Jilid 1. Leberty Yogyakarta. 1990

Hardjana.A. Komunikasi Organisasi. PT.RAJAGRAFINDO PERSADA. 2019.

Santoso, Modul Pembelajaran Komunikasi. 2008, Surabaya

Mulyana.D. Ilmu Komunikasi Suatu Pengantar. PT REMAJA ROSDAKARYA. Bandung. 2007

John Fiske. Pengantar Ilmu Komunikasi. PT. Raja Grafindo Persada 2012

Rakhmat, Jalaluddin. 2009. Psikologi Komunikasi Edisi Revisi. Bandung: Remaja Rosdakarya 


\section{BAB III \\ Pengertian Dan Definisi Komunikasi}

\section{TUJUAN INSTRUKSIONAL UMUM}

Setelah menyelesaikan materi Bab 3 ini mahasiswa diharapkan mampu:

1. Memahami pengertian komunikasi

2. Memahami difinisi komunikasi

3. Mendiskusikan aplikasi komunikasi dalam kehidupan sehari-hari

\section{TUJUAN INSTRUKSIONAL KHUSUS}

Setelah mempelajari Bab 3 ini mahasiswa diharapkan mampu:

1. Menjelaskan pengertian komunikasi

2. Menjelaskan definisi komunikasi

3. Mendiskusikan perkembangan komunikasi bermedia

\subsection{PENGERTIAN KOMUNIKASI}

Kata komunikasi secara etimologis sebenarnya merupakan terjemahan dari bahasa Inggris communication. Communication sendiri berasal dari bahasa latin communis yang berarti "sama atau sama makna", communico atau communicare yang berarti "membuat sama" (to make common) (siapa). Istilah pertama (communis) adalah istilah yang paling banyak digunakan sebagai asal-usul dari kata komunikasi Komunikasi merupakan proses berbagi makna dalam bentuk pesan komunikasi antara pelaku komunikasi. Pesan komunikasi bisa berupa gagasan atau ide pikiran yang diwujudkan dengan simbol yang mengandung makna dan dianut secara sama oleh pelaku komunikasi.

Berbicara tentang definisi komunikasi, tidak ada satu definisi yang tunggal atau hanya satu difinisi komunikasi yang benar. Setiap pakar memberikan difinisi tersendiri sesuai dengan kepakarannya masing-masing, karena itu definisi komunikasi sangat beragam dan banyak sekali. Frank E.X. Dance dalam bukunya, Human Communication 
Theory, mengatakan ada 126 definisi tentang komunikasi. Banyaknya definisi tentang komunikasi menunjukkan betapa luasnya dan beragamnya pengertian dari komunikasi yang dapat dilihat dari berbagai aspek, karena itu definisi tentang komunikasi dikemukakan oleh berbagai pakar ilmu dari dari berbagai disiplin ilmu. Lebih luas komunikasi dapat dilakukan oleh semua makhluk hidup ciptaan tuhan, termasuk hewan dan makhluk halus seperti halnya bangsa jin. Komunikasi didefinisikan secara luas sebagai "berbagi pengalaman". Sampai batas tertentu, setiap makhluk dapat dikatakan melakukan komunikasi dalam pengertian berbagi pengalaman. Edward Depari, dalam (Komuniaksi dalam Organisasi) memberikan pengertian: komunikasi adalah penyampaian gagasan, harapan, dan pesan yang disampaikan melalui lambang tertentu yang mengandung arti dilakukan oleh penyampai pesan (source, komunikator sender) dtujukan kepada penerima pesan (receiver)/communicant, audience, (Widjaja: 1986).

Pengertian komunikasi menurut pakar komunikasi senior Onong Uchjana dapat di tinjau dari dua sudut pandang atau perspektif yaitu komunikasi dalam pengertian secara umum dan pengertian secara paradigmatik. Berikut pengertian komunikasi menurut Onong Uchjana sebagai berikut:

\subsubsection{Pengertian Komunikasi Secara Umum}

Komunikasi dalam pengertian umum dapat dilihat dari dua segi:

a. Pengertian Komunikasi Secara Etimologis

Secara etimologis (asal kata) komunikasi berasal dari bahasa Inggris (communication), dan bersumber dari kata latin communicare atau communis (sama) dalam arti kata sama makna, yaitu sama makna mengenai suatu hal. Jadi komunikasi berlansung apabila antara orang-orang pelaku komunikasi yang terlibat terdapat kesamaan makna mengenai suatu hal yang di komunikasikan. Jelasnya jika seorang mengerti tentang makna pesan yang disampaikan orang lain kepadanya, maka komunikasi akan berlangsung. Begitu juga sebaliknya jika salah satu pelaku komunikasi tidak mengerti makna pesan yang disampaikan, maka komunikasi tidak akan berlangsung.

\section{b. Pengertian Komunikasi Secara Terminologis}

Secara terminologi komunikasi adalah proses penyampaian suatu pertanyaan oleh seseorang kepada orang lain. Jadi, yang terlibat dalam komunikasi itu adalah manusia, karena manusia itu adalah makhluk sosial yang selalu membutuhkan orang lain untuk kelangsungan hidupnya. Jadi konteks komunikasi dalam hal ini adalah komunikasi antar manusia (human communication), yang sering juga disebut 
komunikasi sosial atau (social comunicatioan). Dari pengertian di atas dapat disimpulkan bahwa komunikasi yang di bahas dalam konteks ini bukanlah komunikasi dengan hewan, komunikasi transendental atau komunikasi telepati maupun komunikasi fisik. Meskipun secara khusus komunikasi tersebut dapat dilakukan dan dipelajari seperti ilmu komunikasi pada umumnya. Komunikasi hewan adalah komunikasi antar hewan, misalnya polisi dengan anjing pelacak. Komunikasi transendental adalah komunikasi dengan sesuatu yang bersifat "gaib", termasuk komunikasi dengan Tuhan. Misalnya hubungan dengan yang maha cipta (sholat) contohnya: sholat fardhu, sholat tahajud dan sholat hajat di kalangan pemeluk agama Islam. Komunikasi fisik adalah komunikasi yang hubunganya tempat yang satu dengan tempat yang lain, misalnya dua tempat yang di hubungkan oleh kereta api, bis, pesawat yang mengangkut manusia.

\subsubsection{Pengertian Komunikasi Secara Paradigmatis}

Pengertian komunikasi paradigmatis, bahwa komunikasi selalu mempunyai tujuan tertentu, ada yang di lakukan lisan, secara tatap muka, atau melalui media, baik media massa seperti surat kabar, radio, televisi atau film, media sosial maupun media non massa, misalnya surat, telepon, papan pengumuman, poster, spanduk dan lainya. Diera 4.0 komunikasi mulai banyak mengalami pergeseran dari media maenstrim ke media sosial seperti Facebook, Twitter, Instagram, WhatsApp, Youtube dan lain-lain. Jadi komunikasi dalam pengertian paradigmatis bersifat intensional (intentional), mengandung tujuan; karena itu harus dilakukan dengan perencanaan. Sejauh mana kadar perencanaan itu, bergantung kepada pesan yang akan dikomunikasikan dan pada komunikan yang dijadikan sasaran.

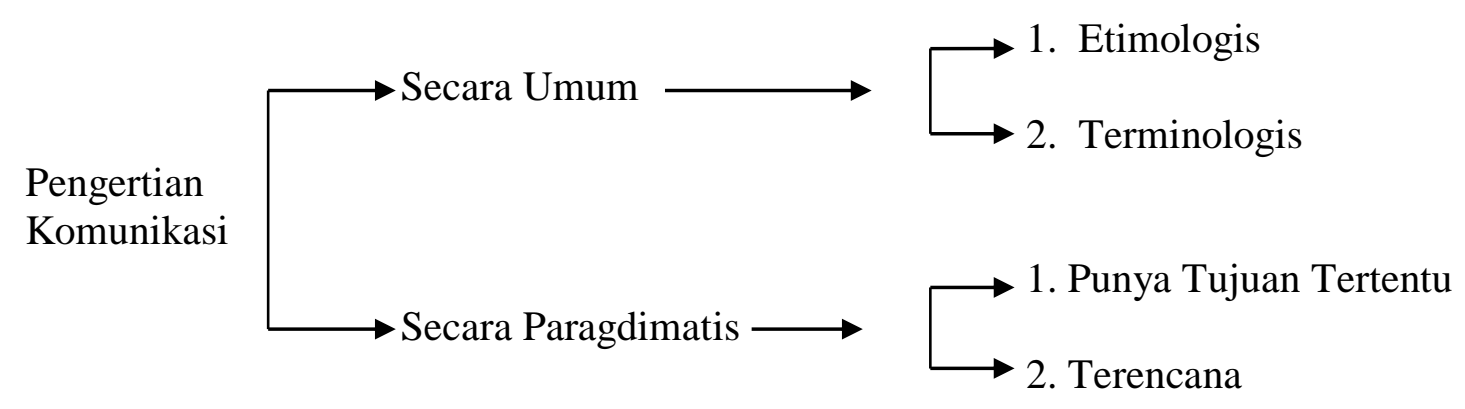

Gambar 3.1: Pengertian komunikasi Menurut Onong Uchjana Efendy 
Penjelasan :

1. Secara Etimologis (arti kata)

(Inggris) Communication

(Latin) Communicare Berpartisipasi /Memberitahukan

Communis Sama (dalam hal pemaknaan)

2. Secara Terminologis

Komunikasi adalah proses penyampaian suatu pernyataan oleh seseorang kepada orang lain sebagai konsekwensi dari interaksi sosial dalam masayakat.

3. Secara Paradigmatis

Komunikasi dapat diartikan sebagai proses penyampaian suatu pesan oleh seseorang kepada orang lain dengan tujuan untuk memberi tahu, merubah sikap atau pendapat dan perilaku, baik langsung secara lisan maupun tidak langsung dengan menggunakan media.

\subsection{DEFINISI KOMUNIKASI}

Banyak difinisi komunikasi yang dirumuskan oleh berbagai pakar dengan sudut pandang yang berbeda. Perbedaan sudut pandang ini tentunya sesuai dengan disiplin ilmu dan kepakaran para ahli. Tentu saja masing-masing definisi tersebut benar dan tidak salah karena disesuaikan dengan bidang dan tujuan mereka masing-masing. Dalam penyusunan difinisi paling tidak harus memenuhi lima syarat :

1. Harus tepat Jangan terlalu pendek dan jangan terlalu panjang. Difinisi dapat dipahami dengan muda dan jelas apa yang dimaksudkan.

2. Harus umum

Artinya difinisi komunikasi harus dapat diterima oleh siapa saja, di mana saja dan kapan saja. Karena itu sifatnya harus universal tidak dikhususkan untuk orang, kelompok atau suku bahkan negara tertentu.

3. Harus jelas

Artinya difinisi komunikasi jangan sirkuler, jangan berputar-putar harus tegas dan lugas apa yang dimaksudkan, karena komunikasi perlu pemahaman yang cepat terkait makna pesan yang disampaikan.

4. Harus positif

Artinya mendifinisikan komunikasi tidak boleh negatif atau pesimis.

5. Tidak menggunakan istilah Metafora 
Artinya mendifinisikan komunikasi tidak boleh menggunakan istilah metafora atau arti yang bukan sebenarnya. Mendifinisikan komunikasi harus jelas memakai kata atau kelompok kata yang tidak menimbulkan multi tasfsir.

\subsubsection{Macam-Macam Definisi Komunikasi}

Dance dalam Mulyana (2001: 54-55) menemukan tiga dimensi konseptual penting yang mendasari defenisi-defenisi komunikasi.

1. Pertama tingkat obserbvasi (level of observation), atau derajat keabstrakannya. misalnya: defenisi komunikasi sebagai "proses yang menghubungkan satu sama lain bagian-bagian terpisah dunia kehidupan" adalah terlalu umum. Sementara komunikasi sebagai "alat untuk mengirim pesan militer, perintah, dan sebagainya lewat telepone, telegraf, radio, kurir dan sebagainya" adalah terlalu sempit.

2. Dimensi kedua adalah kesengajaan (intentionality), sebagaian defenisi mencakup hanya pengiriman dan penerimaan pesan yang disengaja sebagian definisi lainnya tidak menuntut syarat ini. Contoh definisi yang mensyaratkan kesengajaan ini dikemukakan oleh Gerald R. Miller, yakni komunikasi sebagai "situasi-situasi yang memungkinkan suatu sumber mentransmisikan suatu pesan kepada seseorang penerima dengan disadari untuk mempengaruhi penerima". Sedangkan definisi yang mengabaikan kesengajaan adalah definisi yang dinyatakan Alex Gobe, yakni "suatu proses yang membuat sama bagi dua orang atau lebih, yang tadinya merupakan monopoli seseorang atau sejumlah orang" (dalam Mulyana, 2001: 55).

3. Dimensi ketiga adalah penilaian normatif, komunikasi adalah pertukaran verbal pikiran atau gagasan. Sebagian definisi menyamarkan keberhasilan atau kecermatan, sementara yang lainnya tidak seperti itu. Definisi dari John B. Hoben, misalnya mengasumsikan bahwa komunikasi harus berhasil: "komunikasi adalah pertukaran verbal pikiran atau gagasan". Dalam asumsi ini secara implisit mengisyaratkan bahwa suatu pikiran atau gagasan harus dapat dipertukarkan. Sebagian yang lain seperti definisi komunikasi Bernard Berelson dan Gary Steiner; "komunikasi adalah transmisi informasi". Dalam definisi ini tidak mensyaratkan bahwa informasi harus diterima atau dimengerti.

Beberapa contoh difinisi komunikasi sesuai dengan dimensinya:

1. Definisi Demonstratif

Contoh : Kursi itu adalah ini sambil menunjuk kepada benda itu sendiri 
2. Definisi Persamaan

Contoh : Publisistik itu adalah ilmu komunikasi

3. Definisi Yang Luas

Contoh : Ikan adalah hewan yang hidup di air, termasuk Ikan paus, hiu,

Bandeng, Tongkol, dsb.

4. Definisi Lukisan

Menerangkan sesuatu dengan melukiskan ciri-cirinya yang khas.

Contoh : Gajah adalah binatang yang besarnya seperti kereta api yang suaranya juga seperti peluit kereta api, dsb.

5. Definisi Uraian

Contoh : Menerangkan sesuatu dengan menjelaskan satu ciri-ciri dan bagianbagiannya.

\subsubsection{Definisi Komunikasi Menurut Beberapa Pakar}

Pengertian komunikasi sering dikaitkan dengan kehidupan bermasyarakat, dimana setiap orang saling berhubungan antara satu dengan yang lainnya. Dengan melakukan komunikasi berarti bahwa, setiap manusia memberikan suatu aksi yang di respons dengan sebuah reaksi. Berikut ini terdapat beberapa pengertian komunikasi menurut para ahli, antara lain sebagai berikut:

Sebuah definisi komunikasi yang dibuat oleh kelompok sarjana komunikasi yang mengkhususkan diri pada studi komunikasi antar manusia bahwa :

"komunikasi adalah suatu transaksi, proses simbolik yang menghendaki orangorang mengatur lingkungannya (1) dengan membangun hubungan antarsesama manusia (2) melalui pertukaran informasi (3) untuk menguatkan sikap dan tingkah laku orang lain (4) serta berusaha mengubah sikap dan tingkah itu”.'(Cangara 2002:19).

Everett M. Rogers seorang pakar Psikologi Pedesaan Amerika, membuat definisi bahwa:

"Komunikasi adalah suatu proses dimana suatu ide dialihkan dari sumber kepada satu penerima atau lebih, dengan maksud untuk mengubah tingkah laku mereka".

D. Lawrence Kincaid (1981):

"Komunikasi adalah suatu proses dimana dua orang atau lebih membentuk atau melakukan pertukaran informasi dengan satu sama lainnya yang pada gilirannya akan tiba saling pengertian yang mendalam”.

Walter Hagemann

"Komunikasi adalah ajaran tentang pernyataan umum mengenai isi kesadaran yang aktual". 


\section{Adinegoro}

1. Komunikasi adalah ilmu pernyataan antar manusia yang bersifat umum dan aktual.

2. Komunikasi adalah ilmu pernyataan antar manusia, yang umum lagi aktual, dan bertugas menyelidiki secara ilmiah pengaruh pernyataan itu dari mulanya ditimbulkan orang, sampai tersiar di dalam Pers, Radio, dan sebagainya serta akibatnya kepada si penerima pernyataan-pernyataan itu.

\section{Wilbur Schramm}

"Komunikasi berasal dari perkataan Latin yang lain: Communis, yang artinya: Common, sama. Jadi jika kita mengadakan komunikasi dengan sesuatu pihak, maka kita lalu menyatakan gagasan kita untuk memperoleh commones dengan pihak lain mengenai sesuatu objek tertentu”.

Palapah \& Atang Syamsudin

"Komunikasi adalah ilmu tentang pernyataan manusia yang menggunakan lambang-lambang yang berarti".

\section{Carl I. Hovland}

"Komunikasi adalah proses dimana seorang individu (komunikator) mengoperkan stimuli dalam bentuk lambang-lambang bahasa untuk merubah tingkah laku/perilaku individu-individu (komunikate) yang lain.

Joseph A. Devito

"Komunikasi adalah mengacu pada tindakan, oleh satu orang atau lebih, yang mengirim dan menerima pesan yang terdistorsi oleh gangguan (noise), terjadi dalam suatu konteks tertentu, mempunyai pengaruh tertentu dan ada kesempatan untuk melakukan umpan balik”.

William Albig

"Komunikasi adalah proses pengoperan lambang-lambang yang berarti di antara individu-individu".

Neni Yulianita

"Komunikasi adalah proses berbagi makna secara berkesinambungan dan dinamis di antara pelaku-pelaku komunikasi melalui lambang-lambang verbal maupun nonverbal, bermedia ataupun tidak, dimana masing-masing pihak dapat saling memberikan pengaruh secara timbal balik".

\section{Forsdale ( 1981 ),}

"Komunikasi adalah suatu proses memberikan signal menurut aturan tertentu, sehingga dengan cara ini suatu sistem dapat didirikan, dipelihara dan diubah. Definisi komunikasi juga dipandang sebagi suatu proses. Kata signal maksudnya adalah signal yang berupa verbal dan non verbal yang mempunyai aturan tertentu. Dengan adanya aturan ini menjadikan orang yang menerima signal yang telah mengetahui aturannya akan dapat memahami maksud dari signal yang diterimanya. Misalnya setiap bahasa mempunyai aturan tertentu baik bahasa lisan, tulisan maupun isyarat". 


\section{Brent D. Ruben (1988)}

Memberikan definisi mengenai komunikasi manusia yang lebih komperasif sebagai berikut: "Komunikasi manusia adalah suatu proses malalui mana individu dalam hubungannya, dalam kelompok, dalam organisasi dan dalam masyarakat menciptakan, mengirimkan dan menggunakan informasi untuk mengkoodinasi lingkungannya dan orang lain".

Pada definisi komunikasi juga dikatakan dengan suatu proses yaitu suatu aktivitas yang mempunyai beberapa tahap yang terpisah satu sama lain tetapi berhubungan. Istilah menciptakan informasi yang dimaksudkan Ruben disini adalah tindakan menyandikan (encoding ) pesan yang berarti, kumpulan data dari suatu isyarat.

\section{Astrid}

"Komunikasi adalah kegiatan pengoperan lambang yang mengandung arti/makna yang perlu dipahami bersama oleh pihak yang terlibat dalam kegiatan komunikasi”.

\section{Davis, (1981)}

"Komunikasi adalah sebagai pemindahan informasi dan pengertian dari satu orang ke orang lain".

Theodore M. Newcomb:

"Setiap tindakan komunikasi dipandang sebagai suatu transmisi informasi terdiri dari rangsangan yang diskriminatif, dari sumber kepada penerima”.

\section{Raymond S. Ross}

"Komunikasi (intensional) adalah suatu proses menyortir, memilih dan mengirimkan simbol-simbol sedemikian rupa sehingga membantu pendengar membangkitkan makna atau respons dari pikirannya yang serupa dengan yang dimaksudkan komunikator."

Kalau melihat dari beberapa definisi komunikasi yang disampaikan oleh beberapa pakar di atas, bisa disimpulkan bahwa mereka mendefinisikan komunikasi berdasarkan sudut pandang dan latar belakang keilmuan yang dimilikinya, sehingga masing-masing memberikan penekanan atas arti, ruang lingkup dan konteks yang berbeda tentang komunikasi. Ini semakin jelas menunjukkan bahwa ilmu komunikasi adalah ilmu terapan atau Applied science dari beberapa disiplin ilmu. Komunikasi tidak bisa didefinisikan hanya berdasar pada satu sudut pandang saja.

Berdasarkan definisi-definisi komunikasi tersebut di atas, dapat diperoleh gambaran bahwa komunikasi mempunyai beberapa karakteristik diantaranya; 


\section{Komunikasi Adalah Suatu Proses}

Komunikasi sudah menjadi sesuatu yang biasa dilakukan oleh manusia dalam berinteraksi dalam kehidupan bermasyarakat. Kita terkadang tidak menyadari kalau komunikasi sesungguhnya merupakan hasil dari proses artinya komunikasi merupakan serangkaian tindakan atau peristiwa yang terjadi secara berurutan atau dengan tahapantahapan tertentu. Sebagai suatu proses, komunikasi tidak statis, melainkan dinamis dalam arti akan selalu mengalami perubahan dan perkembangan secara terus menerus.

Proses komunikasi melibatkan banyak faktor atau komponen. Faktor- faktor atau unsur yang dimaksud antara lain meliputi komunikator, komunikan, pesan (isi, bentuk, dan cara penyampaiannya), saluran atau media yang digunakan untuk menyampaikan pesan, waktu, tempat, hasil atau akibat yang ditimbulkan dan situasi atau kondisi yang ada ketika komunikasi berlangsung.

\section{Komunikasi Adalah Suatu Upaya Yang Disengaja Serta Mempunyai Tujuan}

Komunikasi adalah suatu kegiatan yang dilakukan secara sadar, disengaja, serta sesuai dengan tujuan atau keinginan dari pelakunya. Pengertian sadar disini menunjukkan bahwa kegiatan komunikasi yang dilakukan seseorang sepenuhnya berada dalam kondisi mental psikologis yang terkendali atau terkontrol, bukan dalam keadaan "mimpi". Disengaja maksudnya bahwa komunikasi yang dilakukan memang sesuai dengan kemauan dari pelakunya. Sementara tujuan merujuk pada hasil atau akibat yang diinginkan. Tujuan komunikasi mencakup banyak hal, tergantung dari keinginan atau harapan dari masing- masing pelakunya.

\section{Komunikasi Menuntut Adanya Partisipasi Dan Kerja Sama Dari Para Pelaku Yang} Telibat.

Kegiatan komunikasi akan berlangsung baik apabila pihak- pihak yang berkomunikasi (dua orang atau lebih) sama-sama ikut terlibat dan sama-sama mempunyai perhatian yang sama terhadap topik pesan yang disampaikan.

\section{Komunikasi Bersifat Simbolis}

Komunikasi pada dasarnya merupakan tindakan yang dilakukan dengan menggunakan lambang-lambang. Lambang yang paling umum digunakan dalam komunikasi antar manusia adalah bahasa verbal dalam kata-kata, kalimat, angka-angka atau tanda-tanda lainnya. Bahasa verbal yang digunakan untuk keperluan membujuk atau meminta tolong, tentunya akan berbeda dengan bahasa yang digunakan untuk tujan 
memerintah atau memaksa. Perbedaanya bukan hanya menyangkut kata-kata yang digunakan, tetapi juga pada tekanan nada atau intonasinya.

Selain bahasa verbal, juga ada lambang-lambang yang bersifat non verbal yang dapat digunakan dalam komunikasi seperti gesture (gerak tangan, kaki atau bagian tubuh lainnya), warna, sikap duduk, berdiri, dan berbagai bentuk lambang lainnya. Penggunaan lambang- lambang nonverbal ini lazimnya dimaksudkan untuk memperkuat makna pesan yang disampaikan.

\section{Komunikasi Bersifat Interaksional}

Komunikasi pada dasarnya menuntut dua tindakan, yaitu memberi dan menerima. Dua tindakan tersebut tentunya perlu dilakukan secara seimbang atau proporsional oleh masing- masing pelaku yang terlibat dalam komunikasi. Apa yang kita terima, nilainya tergantung pada apa yang kita berikan.

Pengertian transaksional juga merujuk pada suatu kondisi bahwa keberhasilan komunikasi tidak hanya di tentukan oleh salah satu pihak, tetapi ditentukan oleh kedua belah pihak yang terlibat dalam komunikasi. Ini berarti bahwa komunikasi akan berhasil apabila kedua belah pihak yang terlibat mempunyai kesepakatan mengenai hal-hal yang dikomunikasikan.

\section{Komunikasi Menembus Faktor Ruang Dan Waktu}

Maksudnya adalah bahwa para peserta atau pelaku yang terlibat dalam komunikasi tidak harus hadir pada waktu serta tempat yang sama. Dengan adanya berbagai produk teknologi komunikasi seperti internet, faximili, dan lain- lain, faktor ruang dan waktu tidak lagi menjadi masalah dalam berkomunikasi.

\subsection{KONSEPTUALISASI KOMUNIKASI}

\subsubsection{Komunikasi Sebagai Tindakan Satu Arah (John R. Wenburg, dkk.)}

Komunikasi sebagai tindakan satu arah adalah suatu perspektif atau pemahaman populer mengenai komunikasi manusia, artinya komunikasi yang mengisyaratkan penyampaian pesan searah dari seseorang (bisa juga sebuah lembaga) kepada seseorang atau sekelompok orang. Komunikasi dianggap suatu proses linear yang di mulai dengan sumber atau pengirim dan berakhir pada penerima, sasaran atau tujuannya. Contoh komunikasi satu arah adalah Pidato/retorika. Michael Burgon menyebutnya sebagai "source oriented defenition" atau defenisi komunikasi 
berorientasi sumber. Inti dari komunikasi sebagai tindakan satu arah adalah sebagai berikut:

Definisi Berorientasi Sumber (Source Orientation Definition)

Komunikasi Dianggap Suatu Tindakan Disengaja (Intentional Act)

Mengabaikan Prosesual Interaksi (Memberi Dan Menerima/Timbal balik)

Contoh definisi yang termasuk dalam tindakan satu arah antara lain Carl Hovland, Harold Lasswell, Everett M. Rogers dan lain-lain.

Suatu pemahaman populer mengenai komunikasi manusia adalah komunikasi yang mengisyaratkan penyampaian pesan searah dari seseorang atau sekelompok orang kepada orang lain atau kelompok lainnya, baik secara langsung (tatap muka) maupun melalui media seperti surat kabar, majalah, radio, televisi. Misalnya, seseorang itu mempunyai informasi mengenai suatu masalah, lalu menyampaikannya kepada orang lain, orang lain itu lalu mendengarkan dan mungkin berperilaku tertentu sebagai hasil mendengarkan pesan tersebut. Dengan demikian, komunikasi dianggap telah terjadi. Jadi, komunikasi dianggap suatu proses linier yang dimulai dengan sumber atau pengirim dan berakhir pada penerima, sasaran atau tujuannya.

Pemahaman komunikasi sebagai suatu proses searah sebenarnya kurang sesuai bila di terapkan pada komunikasi tatap muka, namun mungkin tidak keliru bila di terapkan pada komunikasi publik (pidato) yang tidak melibatkan tanya jawab dan komunikasi massa (cetak dan elektronik).

Pemahaman komunikasi sebagai proses searah ini oleh Michael Bugoon disebut sebagai definisi berorientasi sumber. Definisi seperti ini mengisyaratkan komunikasi sebagai semua kegiatan yang secara sengaja dilakukan seseorang untuk menyampaikan rangsangan untuk membangkitkan respon orang lain. Dalam konteks ini, komunikasi dianggap suatu tindakan yang disengaja untuk menyampaikan pesan demi memnuhi kebutuhan komunikator, seperti membujuk seseorang agar melakukan tindakan tertentu.

Definisi-definisi komunikasi demikian mengabaikan komunikasi yang tidak disengaja, seperti pesan yang tidak di rencanakan yang terkandung dalam nada suara atau ekspresi wajah, atau isyarat lain yang sifatnya spontan.

Singkatnya, konseptualisasi komunikasi sebagai tindakan satu arah menyoroti penyampaian pesan yang efektif dan mengisyaratkan bahwa semua kegiatan komunikasi bersifat persuasif. 


\subsubsection{Komunikasi Sebagai Interaksi (Wilbur Schramm dan Osgood)}

Maksudnya adalah komunikasi berlangsung dua arah: dari komunikator kepada komunikan dan dari komunikan kepada komunikator. Jadi komunikator bisa menjadi komunikan dan komunikan bisa menjadi komunikator. Maksudnya adalah komunikasi berlangsung dua arah: dari komunikator kepada komunikan dan dari komunikan kepada komunikator. Jadi komunikator bisa menjadi komunikan dan komunikan bisa menjadi komunikator

Menyetarakan komunikasi dengan proses sebab akibat atau aksi reaksi yang arahnya bergantian

Mengabaikan kemungkinan bahwa orang-orang dapat mengirim dan menerima pesan pada saat yang sama

Masih berorientasi pada sumber

Proses interaksi masih bersifat mekanis dan statis

Kelebihan konsep ini dari pertama adalah adanya umpan balik

Pandangan ini menyetarakan komunikasi dengan suatu proses sebab akibat atau aksi - reaksi, yang hanya bergantian. Seseorang menyampaikan pesan, baik verbal maupun non verbal, seorang penerima bereaksi dengan memberi jawaban verbal atau menganggukkan kepala, kemudian orang pertama bereaksi lagi setelah menerima respon atau umpan balik dari orang kedua, dan begitu seterusnya.

Pandangan ini lebih maju dari pandangan yang pertama, yaitu sebagai komunikasi sebagai tindakan satu arah, namun pemahaman ini juga kuang memadai dalam menguraikan dinamika proses komunikasi karena mengabaikan kemungkinan bahwa orang- orang dapat mengirim dan menerima pesan pada saat yang sama.

Komunikasi sebagai interaksi dipandang sedikit lebih dinamis daripada komunikasi sebagai tindakan satu arah. Namun pandangan kedua ini masih membedakan para peserta sebagai pengirim dan penerima pesan, karena itu masih tetap berorientasi sumber, meskipun kedua peran tersebut dianggap bergantian. Jadi, pada dasarnya proses interaksi yang berlangsung juga masih bersifat mekanis dan statis.

\subsubsection{Komunikasi Sebagai Transaksi}

Maksudnya adalah proses saling tukar menukar informasi atau proses pengiriman dan penerimaan pesan yang berlangsung secara terus menerus dalam sebuah episode komunikasi. Kata transaksi selalu mengacu pada proses pertukaran dalam suatu hubungan dalam hal ini informasi atau pesan. 
Tidak Terbatas Pada Komunikasi Yang Disengaja

Komunikasi Telah Berlangsung Bila Seseorang Telah Menafsirkan Orang Lain (Verbal/Nonverbal)

Definisi Berorientasi Pada Penerima (Receiver Oriented Definition)

Pihak-Pihak Yang Berkomunikasi Dalam Keadaan interdependensi/Timbal Balik

Semua Unsur Dalam Proses Komunikasi Saling Berhubungan

Pandangan ini mengatakan bahwa komunikasi merupakan suatu proses personal, karena makna atau pemahaman yang diperoleh seseorang pada dasarnya bersifat pibadi. Penafsiran yang kita lakukan terhadap komunikasi verbal dan komunikasi nonverbal orang lain yang kita kemukakan padanya akan mengubah penafsiran orang tersebut terhadap pesan-pesan kita. Pada akhirnya mereka juga akan mengubah makna komunikasi yang kita sampaikan kepadanya.

Jadi dari sudut pandang demikian ini, komunikasi bersifat dinamis, artinya komunikasi dipandang sebagai transaksi. Pandangan ini pula yang dianggap lebih sesuai untuk komunikasi tatap muka yang memungkinkan pesan atau respon verbal dan nonverbal dapat diketahui secara langsung.

\section{Referensi}

Berger, Roloff, Ewoldsen, Handbook Ilmu Komunikasi. Terjemah, Nusa Media 2014 DevitoA.Joseph. Komunikasi antar manusia, edisi kelima terjemah Hunter College of the city University of New York

Frank E.X. Dance dalam bukunya, Human Communication Theory

Onong Uchjana.E. Ilmu Komunikasi Teori dan Praktek. Remaja Karya. Bandung 1995.

Suryanto, Pengantar Ilmu Komunikasi.CV PUSTAKA SETIA. 2015.

Mulyana.D. Ilmu Komunikasi Suatu Pengantar. PT REMAJA ROSDAKARYA. Bandung. 2007

Reed H.Blake And EDWIN O. HAROLDSEN, A.Taxonomy of concepts in Communication, HASTING HOUSE.PUBLISHERS. 1979

Vardiansyah. Pengantar Ilmu Komunikasi. Ghalia Indonesia. 2004

Vardiansyah. Pengantar Ilmu Komunikasi. Ghalia Indonesia. 2004

John Fiske. Pengantar Ilmu Komunikasi. PT. Raja Grafindo Persada 2012

Widjaja. Ilmu Komunikasi Pengantar Studi. PT.Renika Cipta. 1988 


\section{BAB IV}

\section{Proses Dan Komponen Komunikasi}

\section{TUJUAN INSTRUKSIONAL UMUM}

Setelah menyelesaikan materi Bab 4 ini mahasiswa diharapkan mampu:

1. Memahami proses komunikasi

2. Memahami komponen-komponen komunikasi dalam proses komunikasi

3. Memahami hambatan-hambatan dalam proses komunikasi

\section{TUJUAN INSTRUKSIONAL KHUSUS}

Setelah mempelajari Bab 4 ini mahasiswa diharapkan mampu:

1. Menjelaskan proses komunikasi

2. Menjelaskan komponen-komponen komunikasi dalam proses komunikasi

3. Menjelaskan hambatan-hambatan komunikasi dan cara mengatasinya

\subsection{PROSES KOMUNIKASI}

Proses adalah "segala gejala yang mengalami perubahan secara terus-menerus "atau" segala kejadian yang berlangsung terus-menerus". Proses dapat juga diartikan sebagai (1) merupakan perubahan atau serangkaian tindakan serta peristiwa selama beberapa waktu dan yang menuju suatu hal tertentu, (2) Suatu gejala yang menunjukkan perubahan terus menerus terhadap suatu tindakan atau perlakuan yang sedang berlangsung. Proses komunikasi harus melalui beberapa tahapan sesuai dengan komponen utama dalam proses komunikasi, seperti dalam gambar berikut ini:

Dalam menganalisa komunikasi sebagai suatu proses, harus dilihat terlebih dahulu unsur-unsur yang menyebabkan terjadinya sebuah komunikasi, seperti siapa yang berkomunikasi, mengapa dia berkomunikasi, dan kepada siapa komunikasi itu ditujukan. Kita juga harus melihat perilaku komunikasi yang terjadi, pesan yang dihasilkan, bagaimana cara yang dilakukan orang untuk berkomunikasi, bagaimana 
orang mengkemas pesan-pesannya, saluran apa yang dipergunakan untuk menyampaikan pesan kepada pendengar atau pembacanya. Secara sederhana proses komunikasi itu adalah proses pengoperan atau pengiriman serangkaian lambang yang disusun dan dipilih secara sengaja dan mempunyai makna bagi peserta komunikasi.

Sebelum memahami tentang proses komunikasi perlu dijelaskan tentang komponen-komponen dari komunikasi.

Komponen-Komponen Dalam Komunikasi

\section{a. Source (Sumber)}

Sumber adalah dasar yang digunakan di dalam penyampaian pesan dalam rangka memperkuat pesan itu sendiri.

\section{b. Communicator/komunikator (Pengirim pesan)}

Komunikator dapat berupa individu yang sedang berbicara atau menulis, kelompok orang, organisasi komunikasi seperti surat kabar, radio, televise, dan sebagainya.

\section{c. Message (Pesan)}

Pesan adalah lambang atau simbol yang mengandung makna dan dipilih oleh komunikator untuk disampaikan kepada komunikan. Pesan ini dapat berupa verbal maupun non verbal. Pesan secara verbal dapat secara tertulis seperti surat, buku, majalah, memo, sedangkan pesan yang secara lisan dapat berupa, percakapan tatap muka, percakapan melalui telpon dll.

\section{d. Channel (Saluran atau media)}

Chanel atau saluran adalah alat untuk menyalurkan pesan komunikasi. Chanel bisa berupa media elektronik termasuk media sosial maupun media cetak. Saluran komunikasi adalah tempat berlalunya pesan dari komunikator kepada komunikan.

\section{e. Communicant/komunikan (penerima pesan)}

Komunikan adalah penerima pesan atau orang yang menerima pesan yang disampaikan oleh komunikator baik secara langsung maupun menggunakan media.

\section{f. Effect (hasil).}

Dampak yang terjadi pada diri komunikan setelah mendapatkan pesan komunikasi dari komunikator. Hasil antar-efect adalah hasil akhir dari suatu komunikasi yakni sikap dan tingkah laku seseorang sesuai atau tidak sesuai dengan yang kita inginkan. Jika sikap dan tingkah laku ornag lain itu sesuai, 
maka berarti komunikasi itu berhasil. Efek komunikasi bisa pengetahuan, sikap atau perilaku komunikan.

\section{g. Fedback (umpan balik)}

Respon atau efek yang dikembalikan oleh komunikan kepada komunikator setelah mendapatkan pesan komunikasi dari komunikator.

\section{h. Noise (Gangguan)}

Hambatan atau gangguan tak terencana yang terjadi dalam proses komunikasi, akibatnya pesan lain oleh komunikan yang berbeda dengan pesan yang disampaikan oleh komunikator kepadanya.

\subsection{PROSES KOMUNIKASI MENURUT PAKAR}

Proses komunikasi harus melalui beberapa tahapan sesuai dengan komponen utama dalam proses komunikasi, seperti dalam gambar berikut ini:

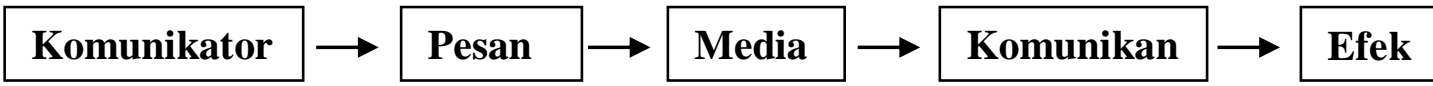

Beberapa proses komunikasi yang disampaikan oleh pakar komunikasi diantaranya adalah:

\section{Edwin B. Flippo}

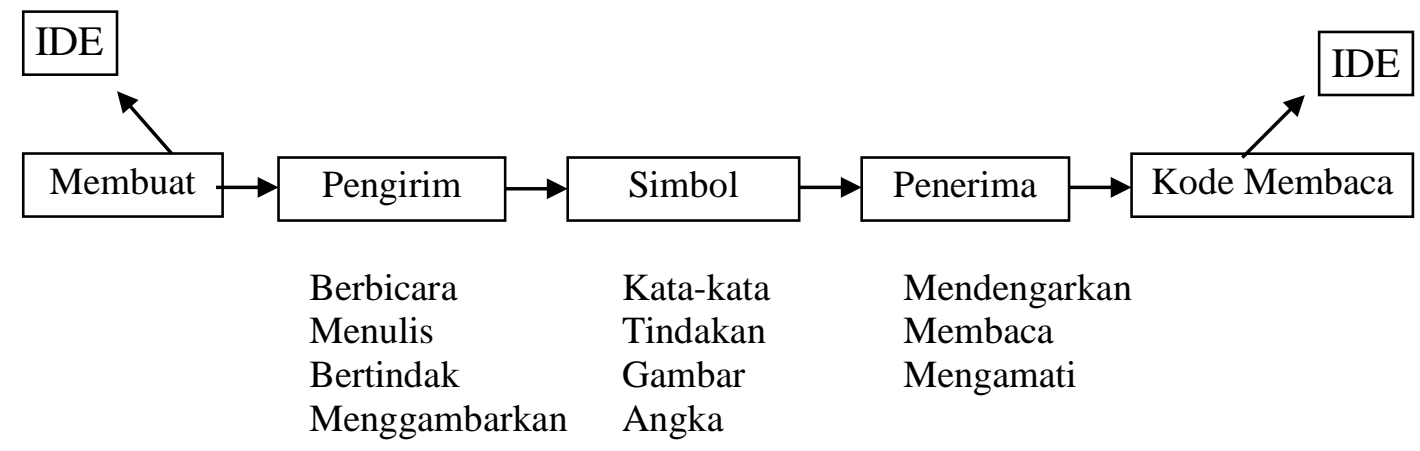

Gambar 4.1: Proses Komunikasi Edwin B. Flippo

Seperti yang ditunjuk gambar diatas, kecakapan komunikasi untuk menyampaikan pengertian atau maksud adalah berbicara, menulis, bertindak, dan menggambarkan, sedangkan mereka yan menerimanya adalah mendengarkan, membaca, dan mengamati. 


\section{Stephen P. Robbins}

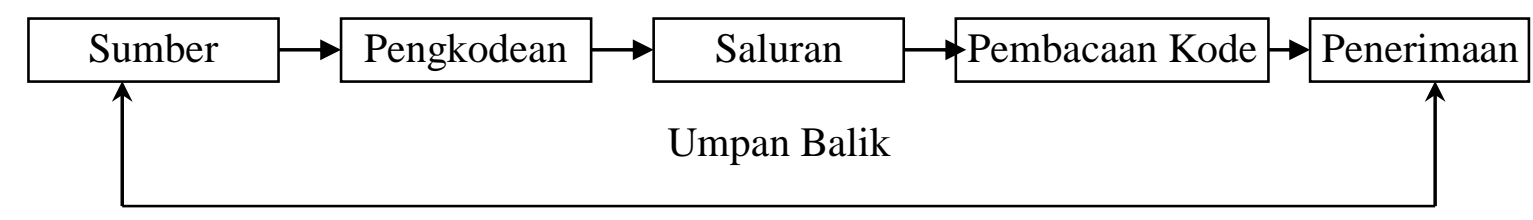

Gambar 4.2: Poses Komunikasi Stephen P. Robbins

Sebelum komunikasi berlangsung diperlukan adanya suatu tujuan yang dinyatakan sebagai suatu pesan yang disampaikan. Pesan ini lewat antara suatu sumber (pengirim) dan penerima. Pesan diubah dalam bentuk simbolik (pengkodean / pembuatan kode) dan melewati jalan media (saluran) ke penerima, yang mengubah kembali pesan pengirim (pembacaan kode).

\section{William B. Werther dan Keitd Davis}

Menurutnya, proses komunikasi adalah metode yang digunakan oleh seorang pengirim untuk menghubungi seorang penerima.

1. Mengembangkan ide atau pikiran yang ingin disampaikan oleh pengirim.

2. Mengkodekan ide-ide dalam kata-kata, bagan-bagan, atau symbol-simbol lain yang sesuai untuk disampaikan.

Menurut Onong Uchana proses komunikasi dibagi menjadi dua yaitu, proses komunikasi primer dan proses komunikasi sekunder.

1. Proses Komunikasi Primer

Proses penyampain pikiran, ide, gagasan atau perasaan seseorong kepada orang lain dengan menggunakan lambang atau simbol sebagai media pertama. Lambang atau simbol adalah sesuatu yang diberi arti oleh peserta komunikasi, yang dapat dimengerti oleh keduanya, karena itu lambang harus merupakan kesepakatan bersama atau umum.

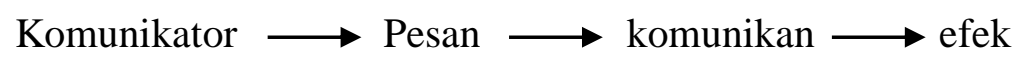

Wilbur Schram dalam bukunya Communication Researc in the united States menyatakan komunikasi akan berhasil bila pesan yang disampaikan oleh 
komunikator sesuai atau cocok dengan kerangka penegetahuan atau acuan (frame of Reference) yang diperoleh oleh setiap individu, serta bidang pengalaman ( field of experience) yang mempengaruhi kemampuan komunikasi.

2. Proses Komunikasi Sekunder

Proses penyampain pikiran, ide, gagasan atau perasaan seseorong kepada orang lain dengan menggunakan saluran atau sarana sebagai media kedua setelah media pertama yang berupa lambang atau simbol. Media digunakan dalam proses sekunder ini dengan tujuan efisiensi dan efektifitas dalam menjangkau komunikan apabila letaknya berjauhan dan jumlahnya sangat banyak. Media yang digunakan adalah media cetak dan media elektronik. Manfaat komunikasi bermedia antara lain:
a. Mencapai masyarakat lebih luas
b. Memungkinkan imitasi oleh lebih banyak orang
c. Mengatasi batas ruang dan waktu.

\subsection{UNSUR-UNSUR DALAM PROSES KOMUNIKASI}

Dalam proses komunikasi terdapat sembilan unsur azasi dari komunikasi ( Onong :19). Masing-masing unsur sangat berkaitan satu sama lainnya, unsur-unsur tersebut diantaranya:

1. Sender: komunikator yang menyampaikan atau mengirimkan pesan kepada komunikan (seseorang atau sejumlah orang)

2. Encoding: Penyandian, yaitu proses pengalihan pikiran, ide dan gagasan seseorang ke dalam bentuk lambang yang mengandung arti yang dapat dimengerti oleh orang lain.

3. Message (pesan): Serangkaian lambang-lambang yang disusun dan dipilih secara sengaja oleh komunikator atau sumber dan mempunyai makna bagi pelaku komunikasi.

4. Media: Saluran komunikasi atau tempat berlalunya pesan dari sumber atau komunikator kepada komunikan atau penerima.

5. Decoding: Pengawasandian, yaitu proses dimana komunikan menetapkan makna atau menginterpretasikan lambang-lambang yang dipilih dalam bentuk pesan yang disampaikan oleh komunikator kepada dirinya (komunikan).

6. Receiver: Komunikan yang menerima pesan dari komunikator. 
7. Efek: Seperangkat reaksi dari komunikan ketika dia menerima pesan komunikasi dari komunikator.

8. Feedback: Umpan balik atau tanggapan komunikan ketika dia mendapatkan pesan kiomunikasi dari komunikator yang dikirim kembali kepada komunikator.

9. Noise: Gangguan dari proses komunikasi yang tidak direncanakan yang mengganggu pesan sehingga membuat perbedaan makna pesan dari komunikator.

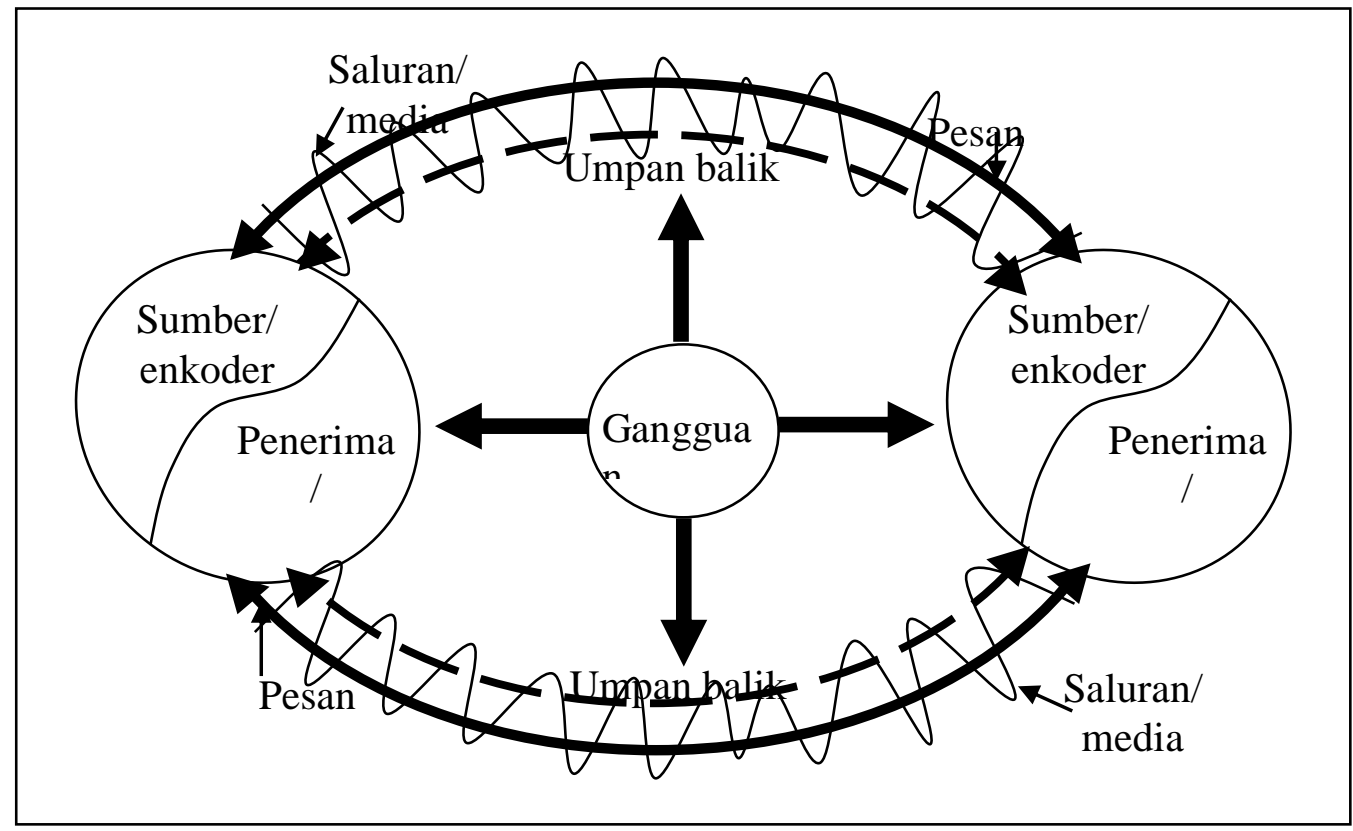

Gambar 4.3: Proses Komunikasi Secara Universal Lawrence Kincaid (1981)

\subsection{LINGKUNGAN KOMUNIKASI}

Menurut De Vito lingkungan (konteks) komunikasi setidak-tidaknya memiliki tiga dimensi:

1. Fisik, adalah ruang dimana komunikasi berlangsung yang nyata atau berwujud.

2. Sosial-psikologis, meliputi, misalnya tata hubungan status di antara mereka yang terlibat, peran yang dijalankan orang, serta aturan budaya masyarakat di mana mereka berkomunikasi. Lingkungan atau konteks ini juga mencakup rasa persahabatan atau permusuhan, formalitas atau informalitas, serius atau senda gurau

3. Temporal (waktu), mencakup waktu dalam hitungan jam, hari, atau sejarah dimana komunikasi berlangsung

Ketiga dimensi lingkungan ini saling berinteraksi; masing-masing mempengaruhi dan dipengaruhi oleh yang lain. Sebagai contoh, terlambat memenuhi 
janji dengan seseorang (dimensi temporal), dapat mengakibatkan berubahnya suasana persahabatan-permusuhan (dimensi sosial-psikologis), yang kemudian dapat menyebabkan perubahan kedekatan fisik dan pemilihan rumah makan untuk makan malam (dimensi fisik). Perubahan-perubahan tersebut dapat menimbulkan banyak perubahan lain. Proses komunikasi tidak pernah statis.

\section{a. Sumber-Penerima}

Kita menggunakan istilah sumber-penerima sebagai satu kesatuan yang tak terpisahkan untuk menegaskan bahwa setiap orang yang terlibat dalam komunikasi adalah sumber (atau pembicara) sekaligus penerima (atau pendengar). Anda mengirimkan pesan ketika anda berbicara, menulis, atau memberikan isyarat tubuh. Anda menerima pesan dengan mendengarkan, membaca, membaui, dan sebagainya.

Tetapi, ketika anda mengirimkan pesan, anda juga menerima pesan. Anda menerima pesan anda sendiri (anda mendengar diri sendiri, merasakan gerakan anda sendiri, dan melihat banyak isyarat tubuh anda sendiri) dan anda menerima pesan dari orang lain (secara visual, melalui pendengaran, atau bahkan melalui rabaan dan penciuman). Ketika anda berbicara dengan orang lain, anda memandangnya untuk mendapatkan tanggapan (untuk mendapatkan dukungan, pengertian, simpati, persetujuan, dan sebagainya). Ketika anda menyerap isyarat-isyarat non-verbal ini, anda menjalankan fungsi penerima.

\section{b. Engkoding-Dekoding}

Dalam ilmu komunikasi kita menamai tindakan menghasilkan pesan (misalnya, berbicara atau menulis) sebagai enkoding (encoding). Dengan menuangkan gagasangagasan kita ke dalam gelombang suara atau ke atas selembar kertas, kita menjelmakan gagasan-gagasan tadi ke dalam kode tertentu. Jadi, kita melakukan enkoding.

Kita menamai tindakan menerima pesan (misalnya, mendengarkan atau membaca) sebagai dekoding (decoding). Dengan menerjemahkan gelombang suara atau kata-kata di atas kertas menjadi gagasan, anda menguraikan kode tadi. Jadi, anda melakukan dekoding.

Oleh karenanya kita menamai pembicara atau penulis sebagai enkoder (encoder), dan pendengar atau pembaca sebagai dekoder (decoder). Seperti halnya sumber-penerima, kita menuliskan engkoding-dekoding sebagai satu kesatuan yang tak terpisahkan untuk menegaskan bahwa anda menjalankan fungsi-fungsi ini secara 
simultan. Ketika anda berbicara (enkoding), anda juga menyerap tanggapan dari pendengar (dekoding).

\section{c. Kompetensi Komunikasi}

Kompetensi komunikasi mengacu pada kemampuan anda untuk berkomunikasi secara efektif (Spitzberg dan Cupach, 1989). Kompetensi ini mencakup hal-hal seperti pengetahuan tentang peran lingkungan (konteks) dalam mempengaruhi kandungan (content) dan bentuk pesan komunikasi (misalnya, pengetahuan bahwa suatu topik mungkin layak dikomunikasikan kepada pendengar tertentu di lingkungan tertentu, tetapi mungkin tidak layak bagi pendengar dan lingkungan yang lain). Pengetabuan tentang tatacara perilaku nonverbal (misalnya kepatutan sentuhan, suara yang keras, serta kedekatan fisik) juga merupakan bagian dari kompetensi komunikasi.

Dengan meningkatkan kompetensi, anda akan mempunyai banyak pilihan berperilaku. Makin banyak anda tahu tentang komunikasi (artinya, makin tinggi kompetensi anda), makin banyak pilihan yang anda punyai untuk melakukan komunikasi sehari-hari. Proses ini serupa dengan proses mempelajari perbendaharaan kata: Makin banyak kata anda ketahui (artinya, makin tinggi kompetensi perbendaharaan kata anda), makin banyak cara yang anda miliki untuk mengungkapkan diri.

\section{d. Pesan}

Pesan komunikasi dapat mempunyai banyak bentuk. Kita mengirimkan dan menerima pesan ini melalui salah satu atau kombinasi tertentu dari panca indra kita. Walaupun biasanya kita menganggap pesan selalu dalam bentuk verbal (lisan atau tertulis), ini bukanlah satu-satunya jenis pesan. Kita juga berkomunikasi secara nonverbal (tanpa kata). Sebagai contoh, busana yang kita kenakan, seperti juga cara kita berjalan, berjabatan tangan, menggelengkan kepala, menyisir rambut, duduk, dan. tersenyum. Pendeknya, segala hal yang kita ungkapkan dalam melakukan komunikasi.

\section{e. Saluran}

Saluran komunikasi adalah media yang dilalui pesan. Jarang sekali komunikasi berlangsung melalui hanya satu saluran, kita menggunakan dua, tiga, atau empat saluran yang berbeda secara simultan. Sebagai contoh, dalam interaksi tatap muka kita berbicara dan mendengarkan (saluran suara), tetapi kita juga memberikan isyarat tubuh dan menerima isyarat ini secara visual (saluran visual). Kita juga memancarkan 
dan mencium bau-bauan (saluran olfaktori). Seringkali kita saling menyentuh, ini pun komunikasi (saluran taktil).

\section{f. Umpan Balik}

Umpan balik adalah informasi yang dikirimkan balik ke sumbernya. Umpan balik dapat berasal dari anda sendiri atau dari orang lain. Dalam diagram universal komunikasi tanda panah dari satu sumber-penerima ke sumber-penerima yang lain dalam kedua arah adalah umpan balik. Bila anda menyampaikan pesan misalnya, dengan cara berbicara kepada orang lain anda juga mendengar diri anda sendiri. Artinya, anda menerima umpan balik dari pesan anda sendiri. Anda mendengar apa yang anda katakan, anda merasakan gerakan anda, anda melihat apa yang anda tulis.

Selain umpan balik sendiri ini, anda menerima umpan balik dari orang lain. Umpan balik ini dapat datang dalam berbagai bentuk: Kerutan dahi atau senyuman, anggukan atau gelengan kepala, tepukan di bahu atau tamparan di pipi, semuanya adalah bentuk umpan balik.

\section{g. Gangguan}

Gangguan (noise) adalah gangguan dalam komunikasi yang mendistorsi pesan. Gangguan menghalangi penerima dalam menerima pesan dan sumber dalam mengirimkan pesan. Gangguan dikatakan ada dalam suatu sistem komunikasi bila ini membuat pesan yang disampaikan berbeda dengan pesan yang diterima.

\section{Hambatan dari Proses Komunikasi}

a. Hambatan dari pengirim pesan, misalnya pesan yang akan disampaikan belum jelas bagi dirinya atau pengirim pesan, hal ini dipengaruhi oleh perasaan atau situasi emosional.

b. Hambatan dalam penyandian/simbol

c. Hal ini dapat terjadi karena bahasa yang dipergunakan tidak jelas sehingga mempunyai arti lebih dari satu, simbol yang dipergunakan antara si pengirim dan penerima tidak sama atau bahasa yang dipergunakan terlalu sulit.

d. Hambatan media, adalah hambatan yang terjadi dalam penggunaan media komunikasi, misalnya gangguan suara radio dan aliran listrik sehingga tidak dapat mendengarkan pesan.

e. Hambatan dalam bahasa sandi. Hambatan terjadi dalam menafsirkan sandi oleh si penerima 
f. Hambatan dari penerima pesan, misalnya kurangnya perhatian pada saat menerima/mendengarkan pesan, sikap prasangka tanggapan yang keliru dan tidak mencari informasi lebih lanjut.

g. Hambatan dalam memberikan balikan. Balikan yang diberikan tidak menggambarkan apa adanya akan tetapi memberikan interpretatif, tidak tepat waktu atau tidak jelas dan sebagainya.

\section{Hambatan sosio-antro-psikologis}

a. Hambatan Sosiologis

Ferdinand Tonnies, mengklasifikasikan kehidupan manusia dalam masyarakat menjadi dua Gemeinschaft ( pergaulan hidup bersifat pribadi, statis, dan tak rasional, seperti dalam kehidupan rumah tang) dan Gessellschaft ( pergaulan hidup yang bersifat tak pribadi, dinamis dan rasional, seperti pergaulan di kantor atau di dalam organisasi).

b. Hambatan Antropologi

Dalam melancarkan komunikasinya seorang komunikator tidak akan berhasil apabila ia tidak mengenal siapa komunikan yang dijadikan sasaranya. Yang di maksud dengan "siapa" di sini bukan nama yang disandang, melainkan rasa apa, bangsa apa, atau suku apa. Dengan mengenal dirinya,akan mengenal pula kebudayaannya, gaya hidup, norma kehidupannya kebiasaan dan bahasanya. Komunikasi akan berlangsung lancar jika suatu pesan yang di sampaikan komunikator diterima oleh komunikan secara tuntas, yaitu diterima dalam pengertian received atau secara inderawi, dan dalam pengertian accepted atau secara rohani.

c. Hambatan Psikologis

Faktor psikologis sering kali menjadi hambatan dalam komunikasi. Hal ini umumnya disebabkan si komunikator sebelum melancarkan komunikasinya tidak terkaji diri komunikan. Berkenaan dengan faktor-faktor penghambat komunikasi yang bersifat sosiologi-antropologi-psikologi itu, yang terjadi permasalahan ialah bagaimana upaya kita mengatasinya: Cara mengatasinya ialah mengenal dengan diri komunikan seraya mengkaji kondisi psikologinya, sebelum komunikasinya dilancarkan, dan bersikap empatik (kemampuan memproyeksikan diri kepada diri orang lain, dengan lain perkataan, kemampuan menghayati perasaan orang lain atau merasakan apa yang di rasakan orang lain) kepadanya.

d. Hambatan Semantis 
Faktor semantis menyangkut bahasa yang di pergunakan komunikator sebagai "alat"untuk menyalurkan pikiran dan perasaannya kepada komunikan. Demi kelancaran komunikasinya seorang komunikator harus benar-benar memperhatikan gangguan semantis ini, hambatan ini disebabkan oleh salah ucap atau salah tulis yang dapat menimbulkan salah pengertian (misunderstanding) atau salah tafsir (misinterpretation), yang pada gilirannya bisa menimbulkan salah komunikasi (miscommunication)

e. Hambatan Mekanis

Yang penting diperhatikan dalam komunikasi ialah seperti telah disinggung di atas, suatu pesan komunikasi dapat di terima secara rohani (accepted) terlebih dahulu harus di pastikan dapat di terima secara inderawi (received) dalam arti kata bebas dari hambatan mekanis. Banyak di jumpai dalam kehidupan sehari-hari hambatan mekanis ini dalam komunikasi. Hambatan mekanis lebih banyak disebabkan oleh alat atau sarana komunikasi (mesin), contohnya komunikasi dengan menggunakan handphon, yang terkadang suaranya putus nyambung tidak jelas, berita surat kabar yang sulit dicari sambungan kolomnya, gambar layar televisi yang tidak jelas, suara radio yang tidak jelas karena berhimpitan dengan suara radio lain. Hambatan mekanis ini juga sangat menganggu dalam proses komunikasi antara komunikator dengan komunikan.

f. Hambatan Ekologis

Hambatan ekologis terjadi dalam proses komunikasi disebabkan oleh gangguan lingkungan terhadap proses berlangsungnya komunikasi. Hambatan ini terjadi diluar komunikator dan komunikan, contohnya suara riuh orang-orang atau kebisingan lalu lintas atau suara mahasiswa yang berbicara ditengah dosen sedang menerangkan materi kuliah.

\subsection{EFEK KOMUNIKASI}

Komunikasi selalu mempunyai efek atau dampak atas satu atau lebih orang yang terlibat dalam tindak komunikasi. Pada setiap tindak komunikasi selalu ada konsekuensi. Sebagai contoh, anda mungkin memperoleh pengetahuan atau belajar bagaimana menganalisis, melakukan sintesis, atau mengevaluasi sesuatu; ini adalah efek atau dampak intelektual atau kognitif. Kedua, anda mungkin memperoleh sikap baru atau mengubah sikap, keyakinan, emosi, dan perasaan anda; ini adalah dampak afektif. Ketiga, anda mungkin memperoleh cara-cara atau gerakan baru seperti cara 
melemparkan bola atau melukis, selain juga perilaku verbal dan noverbal yang patut; ini adalah dampak atau efek psikomotorik.

\subsubsection{Jenis-Jenis Efek}

1. Efek Individual

- Efek Kognitif : Bila ada perubahan pada apa yang diketahui, dipahami, dipersepsi oleh komunikan dengan pikiran.

Efek ini berkaitan dengan transmisi pengetahuan, ketrampilan, kepercayaan dan informasi.

- Efek Afektif : Bila ada perubahan pada apa yang dirasakan, disenangi, dibenci atau perasaan tertentu pada diri komunikan.

Efek ini berkaitan dengan emosi, sikap/nilai

- Efek Behavioral/Konatif : Merujuk pada perilaku nyata yang dapat diamati yang meliputi pola-pola tingkah, kegiatan atau kebiasaan berperilaku.

2. Efek Sosial

- Difusi Informasi

- Opini Publik

- Sosialisasi

- Perubahan Sosial

\subsubsection{Jenis-Jenis Feedback Menurut Beberapa Pakar}

\section{Menurut Ralph Webb, Jr.}

a) External Feedback

Umpan balik yang timbul dari luar diri komunikator

b) Internal Feedback

Umpan balik yang timbul dari dalam diri komunikator

c) Zero Feedback

Umpan balik yang tidak dipahami oleh komunikator.

d) Neutral Feedback

Umpan balik yang diterima kembali oleh komunikatoor tidak relevan dengan pesan yang disampaikan semula.

e) Posistif Feedback 
Komunikasi yang disampaikan oleh komunikator kepada komunikan mendapat tanggapan positif.

f) Negatif Feedback

Komunikan memberikan tanggapan negative terhadap pesan yang disampaikan oleh komunikator.

2. Menurut David K. Berlo

a) Direct/Immediate Feedback

Umpan balik yang segera dapat diterima oleh komunikator

b) Indirect/Delayed Feedback

Umpan balik yang tidak segera diterima oleh komunikator

\section{Menurut Wilbur Schramm}

Inferential Feedback

- Umpan balik yang diterima dalam komunikasi massa yang disimpulkan sendiri oleh komunikator berdasarkan gejala-gejala yang nampak dari komunikan.

Gambar Feedback :

\section{Internal Feedback}

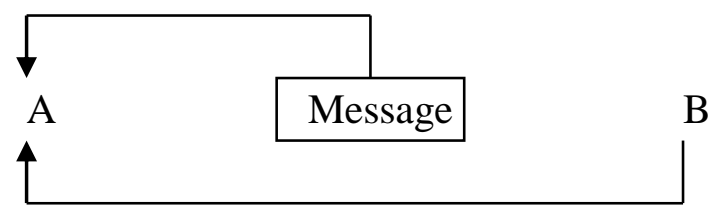

External Feedback

Gambar 4.4: Inferential Feedback

\subsection{ETIK DAN KEBEBASAN MEMILIH}

Karena komunikasi mempunyai dampak, maka ada masalah etik di sini. Karena komunikasi mengandung konsekuensi, maka ada aspek benar-salah dalam setiap tindak komunikasi. Tidak seperti prinsip-prinsip komunikasi yang efektif, prinsip-prinsip komunikasi yang etis sulit dirumuskan.

Seringkali kitadapat mengamati dampak komunikasi, dan berdasarkan pengamatan ini, merumuskan prinsip-prinsip komunikasi yang efektif. Tetapi, kita tidak dapat mengamati kebenaran atau ketidakbenaran suatu tindak komunikasi.

Dimensi etik dari komunikasi makin rumit karena etik begitu terkaitnya dengan falsafah hidup pribadi seseorang sehingga sukar untuk menyarankan pedoman yang 
berlaku bagi setiap orang. Meskipun sukar, pertimbangan etik tetaplah merupakan bagian integral dalam setiap tindak komunikasi. Keputusan yang kita ambil dalam hal komunikasi haruslah dipedomani oleh apa yang kita anggap benar di samping juga oleh apa yang kita anggap efektif.

Apakah komunikasi itu etis atau tidak etis, landasannya adalah gagasan kebebasan memilih serta asumsi bahwa setiap orang mempunyai hak untuk menentukan pilihannya sendiri. Komunikasi dikatakan etis bila menjamin kebebasan memilih seseorang dengan memberikan kepada orang tersebut dasar pemilihan yang akurat. Komunikasi dikatakan tidak etis bila mengganggu kebebasan memilih seseorang dengan menghalangi orang tersebut untuk mendapatkan informasi yang relevan dalam menentukan pilihan. Oleh karenanya, komunikasi yang tidak etis adalah komunikasi yang memaksa seseorang (1) mengambil pilihan yang secara normal tidak akan dipilihnya atau (2) tidak mengambil pilihan yang secara normal akan dipilihnya. Sebagai contoh, seorang pejabat rekruting perusahaan mungkin saja membesar-besarkan manfaat bekerja di Perusahaan $\mathrm{X}$ dan dengan demikian mendorong anda untuk menentukan pilihan yang secara normal tidak akan anda ambil (jika saja anda mengetahui fakta-fakta sebenarnya).

Dalam etik yang didasarkan atas kebebasan memilih ini, ada beberapa persyaratan. Kita mengasumsikan bahwa orang-orang ini sudah cukup umur dan berada dalam kondisi mental yang memungkinkan mereka melaksanakan pilihan secara bebas. Selanjutnya, kita mengasumsikan bahwa kebebasan memilih dalam situasi mereka tidak akan menghalangi kebebasan memilih orang lain. Sebagai contoh, anak-anak berusia 5 atau 6 tahun tidak akan siap untuk menentukan pilihan sendiri (memilih menu mereka sendiri, memilih waktu untuk tidur, memilih jenis obat), sehingga harus ada orang lain yang melakukannya untuk mereka. Begitu juga, seseorang yang menderita keterbelakangan mental membutuhkan orang lain untuk mengambilkan keputusan tertentu bagi mereka.

Di samping itu, situasi lingkungan kehidupan seseorang dapat membatasi kebebasan memilih ini. Sebagai contoh, anggota tentara seringkali harus melepaskan kebebasan memilih dan makan nasi bungkus, bukan roti keju, mengenakan seragam militer, bukan jins, lari pagi, bukan tidur. Dengan menjadi tentara, seseorang setidaktidaknya harus melepaskan sebagian hak mereka untuk menentukan pilihan sendiri. Akhirnya, kebebasan memilih yang kita miliki tidak boleh menghalangi orang lain untuk menentukan pilihan mereka sendiri. Kita tidak bisa membiarkan seorang pencuri 
memiliki kebebasan untuk mencuri, karena dengan memberikan kebebasan ini kita menghalangi korban pencurian untuk menikmati kebebasan memilih hak untuk memiliki barang dan hak untuk merasa aman dalam rumah mereka.

\section{Referensi}

Cangara. H. Pengantar Ilmu Komunikasi.PT RajaGrafido Persada.Depok 2000

DevitoA.Joseph. Komunikasi antar manusia, edisi kelima terjemah Hunter College of the city University of New York

Onong Uchjana.E. Dinamika Komunikasi.Remaja Karya CV. Bandung. 1986

Roudhonah, Ilmu Komunikasi. PT RajaGrafido Persada.Depok 2000

Sri Moerdijati. Buku Ajar Pengantar Komunikasi. Revka Petra Media 2012

Yulianita, Modul Pembelajaran Mata Kuliah Pengantar Komunikasi. 2008. Surabaya Vardiansyah. Pengantar Ilmu Komunikasi. Ghalia Indonesia. 2004

Berger, Roloff, Ewoldsen, Handbook Ilmu Komunikasi. Terjemah, Nusa Media 2014

John Fiske. Pengantar Ilmu Komunikasi. PT. Raja Grafindo Persada 2012 


\section{BAB V}

\section{Tujuan Dan Fungsi Komunikasi}

\section{TUJUAN INSTRUKSIONAL UMUM}

Setelah menyelesaikan materi Bab 5 ini mahasiswa diharapkan mampu:

1. Memahami tujuan komunikasi

2. Memahami fungsi komunikasi

3. Memahami aplikasi dari komunikasi dalam kehidupan sehari-hari

\section{TUJUAN INSTRUKSIONAL KHUSUS}

Setelah mempelajari materi Bab 5 ini mahasiswa diharapkan mampu:

1. Menjelaskan tujuan manusia melakukan komunikasi

2. Menjelaskan fungsi dari komunikasi

3. Mendiskusikan tujuan dan fungsi komunikasi dalam kehidupan sehari-hari

\subsection{TUJUAN KOMUNIKASI}

Gordon (1971:37) mengatakan tujuan yang hendak dicapai dalam komunikasi adalah kualitas seluruh komunikasi itu, seperti "motivasi", termasuk dalam seluruh tingkah laku sepanjang komunikasi dan / tingkah laku itu melibatkan manusia.

Tujuan utama dari proses komunikasi adalah untuk mempengaruhi, menimbulkan empati, menyampaikan informasi, menarik perhatian dan sebagainya. Namun secara universal tujuan dari komunikasi dapat di kelompokkan menjadi :

1. Mengubah Sikap (Attitude Change)

2. Mengubah Opini (Opinion Change)

3. Mengubah Perilaku (Behavior Change) 
Selain tujuan di atas komunikasi juga dapat digunakan dalam mempermudah interaksi antar pelaku komunikasi seperti:

1. Untuk mempermudah menyampaikan ide, pikiran gagasan agar dimengerti oleh para pelaku komunikasi.

2. Memahami orang lain

3. Menggerakkan orang lain untuk melakukan sesuatu

Jadi secara singkat dapat kita katakan bahwa komunikasi itu bertujuan: mengharapkan pengertian, dukungan, gagasan dan tindakan. Setiap komunikasi tentunya mempunyai tujuan bagi para pelaku komunikasi sesuai dengan karakteristik masing-masing pelaku komunikasi.

Tujuan komunikasi dari sudut kepentingan sumber atau komunikator

1. Memberikan informasi

2. Mendidik

3. Menyenangkan/menghibur

4. Menganjurkan suatu tindakan/persuasi

Tujuan komunikasi dari sudut kepentingan penerima

1. Memahami informasi

2. Mempelajari

3. Menikmati

4. Menerima atau menolak anjuran

Tujuan komunikasi dipandang dari kepentingan sosial

1. Berbagai pengetahuan umum tentang lingkungan di sekitarnya

2. Sosialisasi peran, nilai dan kebiasaab terhadap anggota-anggota baru

3. Memberikan hiburan kepada warga masyarakat, menciptakan bentuk-bentuk kesenian baru dan lain-lain

4. Pencapaian konsesus dan mengontrol tingkah laku

Tujuan komunikasi dipandang dari kepentingan individual

1. Menguji, mempelajari dan memperoleh gambaran tentang realitas, kesempatan dan bahaya.

2. Memperoleh pengetahuan dan keterampilan untuk hidup bermasyarakat

3. Menikmati hiburan, rilek melarikan diri dari kesulitan hidup sehari-hari dan lain-lain.

4. Menentukan keputusan/pilihan bertindak sesuai aturan sosial.

Secara umum akibat atau hasil dari komunikasi ini mencakup tiga aspek, diantaranya: 
1. Aspek kognitif, yang menyangkut kesadaran dan pengetahuan, misalnya menjadi sadaratau ingat, menjadi tahu atau kenal

2. Aspek afektif, yaitu menyangkut sikap atau perasaan/emosi. Misalnya: sikap setuju/tidak setuju, perasaan sedih, gembira, perasaan benci, dan menyukai.

3. Aspek psikomotor, yaitu menyangkut perilaku / tindakan. Misalnya, berbuat seperti apa yang disarankan atau berbuat sesuatu tidak seperti apa yang disarankan (menentang).

Pendapat JOSEPH A. DEVITO tentang tujuan komunikasi adalah sebagai berikut :

1. Penemuan Diri

2. Untuk Berhubungan

3. Untuk Meyakinkan

4. Untuk Bermain

Sedangkan menurut pendapat DAVID K. BERLO tujuan komunikasi adalah :

1. The Who Of Purpose

2. The How Of Purpose

\subsection{FUNGSI KOMUNIKASI}

Komunikasi antar manusia merupakan suatu rangkain proses yang halus dan sederhana. Selalu dipenuhi dengan berbagai unsur sinyal, sandi, arti-fak peduli bagaimana sederhananya sebuah pesan atau kegiatan itu. Komunikasi antar manusia juga merupakan rangkaian proses yang beraneka ragam. Komunikasi mewujudkan tiga fungsi utama:

1. Komunikasi membentuk dunia sekeliling bagi individu

2. Komunikasi menetapkan kedudukan individu sendiri dalam hubungannya dengan orang lain

3. Komunikasi membantu individu dalam menyesuaikan diri dengan sekelilingnya (Hartley dan Hartley, 1961 : 9)

Sedangkan fungsi komunikasi menurut beberapa pakar diantaranya :

\section{Deddy Mulyana}

\section{Komunikasi Sosial}

a. Pembentukan Konsep Diri

b. Pernyataan Eksistensi Diri

c. Kelangsungan Hidup

d. Memupuk Hubungan 


\section{e. Memperoleh Kebahagiaan}

Konsep diri ialah pandangan kita tentang siapa diri kita yang diperoleh dari infomasi yang diberikan orang lain kepada kita. Manusia yang tidak pernah berkomunikasi dengan manusia lainnya tidak mungkin mempunyai kesadaran bahwa dirinya adalah manusia. Kita sadar bahwa kita manusia karena orang- orang di sekeliling kita lewat perilaku verbal dan non verbal mereka bahwa kita manusia.

Melalui komunikasi dengan orang lain, baik verbal maupun non verbal, kita menjadi mengetahui siapakah diri kita sebenarnya. Konsep diri yang paling dini terbentuk melalui keluarga, dan orang- oang lain yang dekat dengan kita seperti ayah, ibu, dan orang- orang yang sekerabat dengan kita. Mereka itulah yang disebut significant others. Orang tua kita, atau siapapun yang memelihara kita ketika kita kecil, mengatakan kepada kita lewat ucapan dan tindakan mereka bahwa kita baik, nakal, rajin, cantik, sopan, dan sebagainya. Merekalah yang mengajari kita tentang kata- kata dan bahasa untuk petama kali.

Aspek-aspek konsep diri seperti jenis kelamin, usia, agama, suku, pendidikan, pengalaman, bentuk muka, hobby, dan sebagainya kita internalisasikan lewat pernyataan (umpan balik) oang lain yang menegaskan aspek- aspek tersebut kepada kita, dan pada gilirannya menuntut kita berperilaku sebagaimana orang lain memandang kita. Menurut para ahli, konsep diri berupa identitas etnik meupakan unsur konsep diri yang penting, yang diartikan sebagai "perasaan kontinuitas dengan masa lalu, perasaan yang dipupuk sebagai bagian penting defenisi diri”. Dalam konteks ini, identitas diri, identitas etnik seseorang berkembang melalui internalisasi atas "kekuasaan" (typication) diri oleh oang lain, khususnya orang- orang dekat sekitarnya, mengenai siapa orang itu dan siapa orang lain berdasarkan latar belakang etnik.

Charles H. Cooley menyebutkan konsep diri itu sebagai the looking glass-self yang secara signifikan ditentukan oleh apa yang seseorang pikirkan mengenai oang lain terhadapnya. Jadi menekankan respon orang lain yang di interpetasikan secara subjektif sebagai sumber primer data mengenai diri sendiri.

Etnik atau kesukuan, di samping agama, secara tradisional merupakan aspek terpenting dari konsep diri kita. Begitu pentingnya asal- usul itu, kita akan melakukan apa saja untuk memastikan bahwa kita memiliki dimensi terpenting identitas kita tesebut.

Konsep diri kita tidak pernah terisolasi, melainkan begantung pada reaksi dan respon orang lain. Dalam masa pembentukan konsep diri itu penting, kita sering 
mengujinya, baik secara sadar maupun tidak sadar. Dalam permainan peran ini, keinginan kita untuk menciptakan konsep diri kita mungkin memperoleh dukungan, berubah atau mendapatkan penolakan. Dengan cara ini, interpretasi orang lain mengenai bagaimana kita seharusnya membantu untuk menentukan akan menjadi apa kita nanti. Bisa jadi, kita mungkin akan menjadi seperti apa yang diharapkan orang lain kepada kita.

Kesan orang lain kepada diri kita dan cara mereka bereaksi terhadap kita sangat bergantung pada cara kita berkomunikasi dengan mereka, termasuk cara kita berbicara dan berpakaian. Proses umpan balik ini dapat berubah arah. Ketika kita melihat orang lain bereaksi terhadap kita dan kesan yang mereka miliki tentang diri kita, boleh jadi kita akan mengubah cara kita berkomunikasi karena reaksi orang lain itu tidak sesuai dengan cara kita memandang diri kita. Jadi citra yang anda miliki tentang diri anda dan citra yang orang lain miliki tentang diri anda bekaitan dalam komunikasi.

Pernyataan eksistensi diri. Orang berkomunikasi menunjukkan bahwa dirinya eksis. Ketika kita berbicara dan berkomunikasi dengan oang lain, baik verbal maupun nonverbal, ini menunjukkan bahwa dii kita eksis atau ada.

Dengan dasar ucapan filosof Perancis, Rene Descartes mengatakan "Cogito Ergo Sum" (saya berpikir, maka saya ada) kita juga dapat mengatakan bahwa "Saya berbicara, maka saya ada". Bila kita diam saja dalam suatu rapat, maka orang lain akan memperlakukan seolah- olah kita tidak ada. Fungsi komunikasi sebagai eksistensi diri terlihat jelas ketika orang mendominasi pembicaraan dalam dialog, seminar atau rapat.

Untuk kelangsungan hidup, memupuk hubungan dan mencapai kebahagiaan. Sejak manusia lahir, ia tidak dapat hidup sendiri untuk mempetahankan hidupnya. Manusia perlu dan harus bekomunikasi dengan orang lain untuk memenuhi kebutuhan hidupnya seperti makan, minum dan mencapai kebahagiaan.

Menurut para psikolog, kebutuhan utama kita sebagai manusia yang sehat secara rohaniah adalah kebutuhan akan hubungan sosial yang ramah, dan ini hanya bisa dicapai dengan membina hubungan sosial yang baik dengan orang lain. Abraham Maslow mengemukakan kebutuhan dasar manusia, yaitu kebutuhan fisiologis, keamanan, dan kebutuhan sosial, penghargaan diri, dan kebutuhan aktualisasi diri.

Komunikasi, dalam konteks apapun adalah kebutuhan dasar adaptasi terhadap lingkungan. Rene Spitz mengatakan, komunikasi atau ucapan adalah jembatan yang menghubungkan antara bagian luar dan bagian dalam kepribadian manusia. 
Melalui komunikasi kita dapat memenuhi kebutuhan emosional kita dan meningkatkan kesehatan mental kita. Kita belajar cinta kasih, keakaban, rasa hormat, simpati, bangga, rasa cemburu dan rasa benci. Melalui komunikasi kita dapat mengalami bebagai kualitas perasaan tersebut dan membandingkan perasaan yang satu dengan perasaan yang lain.

Bila kita berada di tengah kumpulan orang- orang dan eksistensi kita tidak dianggap oleh mereka, maka kita akan merasa tidak nyaman dibuatnya. Ini menggambarkan bahwa pengakuan orang lain akan eksistensi kita sangat berarti bagi kita. Utuk memperoleh kesehatan emosional, kita harus memupuk perasaan- perasaan positif dan menetralkan peasaan- perasaan negatif. Oang yang tidak penah merasakan kasih sayang dari orang lain akan mengalami kesulitan untuk melakukan hal yang sama pada orang lain, karena ia sendiri tidak pernah mengenal dan merasakan perasaan itu.

Dalam kehidupan sehari- hari, secara sada ataupun tidak, kita sering mengucapkan kata- kata dan sapaan yang mana hal itu menunjukkan bahwa kita ramah, peduli dengan orang lain, dan untuk menumbuhkan atau memupuk kehangatan dan keakraban dengan orang lain. Komunikasi seperti ini disebut komunikasi fatik (phatic communication).

Komunikasi sosial mengisyaratkan bahwa komunikasi dilakukan untuk pemenuhan diri, untuk menghibur diri, merasa nyaman dan tentram dengan diri sendiri dan orang lain. Mungkin pembicaraan antara dua sahabat bisa berlangsung lama dan mengenai hal- hal yang sepele, akan tetapi pembicaraaan kedua orang itu membuat mereka senang. Penelitian para psikolog membuktikan bahwa banyak perilaku manusia dimotivasi oleh kebutuhan untuk menjaga keseimbangan emosional ataumengurangi ketegangan internal dan rasa frustasi. Itulah sebabnya, kita memahami mengapa seseoang yang mengemukakan persoalan pribadinya kepada orang lain yang dipercayainya merasa beban emosionalnya berkurang.

\section{Komunikasi Ekspresif}

a. Mengekspresikan Perasaan (Emosi)

b. Mengekspresikan Kesadaran

c. Mengekspresikan Pandangan Hidup

Erat kaitannya dengan komunikasi sosial adalah komunikasi ekspresif yang dilakukan secara sendiri dan kelompok. Komunikasi ekspresif tidak otomatis bertujuan mempengaruhi orang lain, namun dapat dilakukan sejauh komunikasi tersebut menjadi instrumen untuk menyampaikan perasaan kita. Perasaan- perasaan tersebut 
dikomunikasikan melalui pesan- pesan non verbal. Seperti, peasaan sayang, marah, benci, takut, sedih dan simpati.

Seorang ibu memperlihatkan kasih sayangnya dengan cara memeluk dan mencium anaknya. Atasan menunjukkan simpatinya kepada bawahannya yang sedang berduka dengan cara menepuk bahunya. Orang- orang mengekspresikan kemarahan dan kekecewaannya dengan caa beteriak, demonstrasi, berkacak pinggang, melotot dan sebagainya.

Kita dapat menyatakan kasih atau ucapan selamat pada seseorang yang berulang tahun dan lulus sajana dengan cara memberikan bunga. Komunikasi ekspresif dapat pula dikomunikasikan melalui karya seni seperti puisi, lukisan, tarian, musik, dan sebagainya.

Musik juga dapat mengekspresikan perasaan, kesadaran bahkan pandangan hidup dan ideologi manusia. Itulah sebabnya pertunjukan musik dari beberapa artis penyanyi seperti Gombloh, dan Iwan Fals membawakan lirik- liriknya yang bermuatan cinta, penderitaan orang, atau kritik terhadap penguasa.

Lukisan juga sering mengekspresikan perasaan pelukisnya, seperti lukisan Affandi, Dede Eri Kurnia, atau Soedjojono memperlihatkan nuansa jiwanya yang terdalam yang tergambar dari penggunaan warna dan bentuk- bentuk garis dalam lukisannya.

\section{Komunikasi Ritual}

Upacara-upacara yang berkaitan dengan tradisi keluarga, suku, bangsa, negara, ideology dan agama. Erat kaitannya dengan komunikasi ekspresif adalah komunikasi ritual, yang biasanya dilakukan secara kolektif. Suatu komunitas sering melakukan upacaa- upacara belainan sepanjang tahun dan sepanjang hidup, yang disebut para antropolog sebagai rises of passage, mulai dari upacara tujuh bulanan, kelahiran, sunatan, ulang tahun, pertunangan, pernikahan, naik haji ke Mekkah, dan sebagainya.

Dalam upacara- upacara tersebut orang- orang mengucapkan kata- kata atau menampilkan perilaku tertentu bersifat simbolik. Ritus- ritus lainnya seperti shalat, upacara bendera, wisuda, Natal dan Lebaran. Mereka berpartisipasi dalam bentuk komunikasi ritual tersebut menegaskan kembali komitmen mereka kepada tradisi keluarga, suku, bangsa, negara, ideologi, atau komitmen pada agama mereka.

Komunikasi ritual seringkali juga bersifat ekspresif, artinya menyatakan perasaan terdalam seseorang, misalnya seorang anggota paskibraka berlinangan air mata ketika mencium bendera pusaka merah putih. Kegiatan komunikasi ritual 
memungkinkan para pesertanya berbagi komitmen emosional dan menjadi perekat bagi keterpaduan mereka. Yang menjadi esensi bukanlah kegiatan ritualnya, akan tetapi adanya perasaan senasib sepenanggungan yang menyertainya, artinya adanya perasaan bahwa kita terikat oleh sesuatu yang lebih besar dari diri kita diakui dan diterima oleh kelompok kita.

Sebagian respon kita terhadap lambang dalam beberapa konsep atau istilah seperti cinta, suku, bangsa, negara, agama, atau apa saja yang ada dalam hidup dan kehidupan kita, mungkinsaja tidak kita sadari. Respon manusia dalam menanggapi lambang- lambang ini tidak jarang besifat ekstrem dan tidak masuk akal bagi kebanyakan orang. Misalnya sepasang muda- mudi bunuh diri karena tidak direstui oleh orang tua, atau paa mujahid dan militan yang melakukan bunuh diri dengan meledakkan dirinya di tengah- tengah keumunan orang. Bahkan dahulu para prajurit Jepang melakukan bunuh diri secara terencana dan melalui suatu upacara itual.

Kegiatan ritual memungkinkan para pesertanya berbagi komitmen emosional dan menjadi perekat bagi kesatuan kelompok, dan merupakan pengabdian bagi kelompok dimana individu tersebut menjadi anggotanya. Yang mejadi perhatian dan hal yang terpenting bukanlah substansi kegiatan ritual itu sendiri, melainkan perasaan terikat oleh sesuatu yang lebih besar daripada kita sendiri, dan kita bersedia berkoban untuknya.

Komunikasi ritual ada kalanya bersifat mistik dan seringkali perilaku orangorang dalam komunitas tersebut sulit dimengerti dan dipahami oleh orang- orang yang berada di luar komunitas. Contoh yang dapat dikemukakan adalah upacara- upacara ritual di beberapa suku pedalaman indonesia seperti Asmat, suku Badui, Dayak dan beberapa suku lainnya yang mata pencahariannya adalah bertani, menangkap ikan di sungai atau laut, atau berburu binatang.

Komunikasi ritual ini bisa jadi akan tetap ada sepanjang zaman, karena ia merupakan kebutuhan manusia, meskipun bentuknya berubah- ubah demi pemenuhan kebutuhan dirinya sebagai makhluk individu, anggota komunitas tertentu, makhluk sosial, dan sebagai salah satu bagian dai alam semesta.

\section{Komunikasi Instrumental}

a. Menginformasikan

b. Mengajar

c. Mendorong

d. Menghibur 
e. Mengubah Sikap \& Keyakinan

f. Mengubah Perilaku dan

g. Menggerakkan Tindakan

Jika diringkas, maka kesemua tujuan tersebut di atas dapat dikelompokkan membujuk atau bersifat persuasif. Komunikasi yang berfungsi memberitahukan atau menerangkan mengandung muatan persuasif dalam arti bahwa pembicara menginginkan pendengarnya mempercayai bahwa informasi yang disampaikannya akurat dan layak untuk diketahui.

Sebagai instrumen, komunikasi tidak saja kita gunakan untuk menciptakan dan membangun hubungan, akan tetapi juga sekaligus untuk merusak dan menghancurkan hubungan tersebut. Itulah sebabnya, dalam ilmu komunikasi dikenal tentang studi tentang strategi komunikasi, yang antaa lain dapat digunakan aga kita dapat bekomunikasi secara efektif dengan oang lain demi keuntungan bersama.

Komunikasi berfungsi sebagai instrumen untuk mencapai tujuan- tujuan pribadi dan pekerjaan, baik tujuan jangka pendek maupun jangka panjang. Tujuan jangka pendek misalnya untuk memperoleh pujian, menimbulkan kesan yang baik, memperoleh simpati, empati, dan keuntungan ekonomi melalui taktik- taktik verbal dan nonverbal seperti seperti berbicara sopan, mengobral janji, mengenakan pakaian necis. Taktik seperti ini biasanya digunakan oleh orang- orang yang kampanye politik.

Tujuan jangka panjang dapat diaih melalui keterampilan komunikasi, misalnya keahlian bepidato, berrunding, ataupun keahlian menulis. Hasil penelitian menunjukkan bahwa kemampuan meningkatkan manfaat komunikasi antarpribadi merupakan suatu keahlian istimewa, tidak hanya bagi pengembangan pribadi dan keluarga, akan tetapi juga peningkatan karir.

Komunikasi internal haus diakui sebagai alat penting bagi manajemen. Ada kebutuhan khusus bagi setiap manajer untuk memahami bahwa komunikasi yang baik adalah cara untuk mencapai tujuan perusahaan. Disamping itu, komunikasi adalah cara untuk membangun kerja sama tim yang lebih baik, bahkan komunikasi adalah cara untuk memperoleh uang.

Jadi jelaslah, bahwa melalui komunikasi para pemimpin politik harus mengemukakan pandangan di tengah- tengah masyarakat, penguasa, atau dihadapan komunitas tertentu. Pemikiran- pemikiran dan pandangan- pandangan mereka ini pada gilirannya akan membangun kredibilitas mereka sebagai pemimpin. 
Keahlian komunikasi juga memberikan kontibusi bagi kesuksesan karir. Karena pekerjaan atau profesi seperti dosen, guru, manajer, politisi, Public Relations Officer (PRO), salesman, wartawan, atau pengacara menuntut keteampilan dan kemampuan berbicara, berpidato, keahlian bergaul dan meyakinkan orang lain, berunding, dan memimpin rapat.

\section{Lasswell}

a. Pengawasan/Mengontrol Lingkungan

b. Beradaptasi Dengan Lingkungan

c. Transformasi Warisan Sosialisasi/Budaya

$\checkmark$ Pemberian Informasi

$\checkmark$ Pemberian Komentar/Interpretasi untuk membantu pemahaman makna informasi

$\checkmark$ Ekspresi nilai dan symbol budaya untuk melestarikan identitas suatu masyarakat

\section{Onong Uchjana Effendy}
a. Menginformasikan
b. Mendidik
c. Menghibur
d. Mempengaruhi

\section{Palapah}

a . Fungsi Pribadi:

$\checkmark \quad$ untuk melepaskan ketegangan

$\checkmark \quad$ untuk mencapai kepuasan pribadi

b. Fungsi Sosial: (Sama dengan yang dari Lasswell)

\section{Hafied Cangara}

a. Komunikasi Dengan Diri Sendiri

$\checkmark$ Mengembangkan Kreativitas Imajinasi

$\checkmark$ Memahami dan Mengendalikan Diri

$\checkmark$ Meningkatkan Kematangan Berpikir Sebelum Mengambil Keputusan

b. Komunikasi Antar Pribadi

$\checkmark$ Meningkatkan Hubungan Insani 
$\checkmark$ Menghindari dan Mengatasi Konflik Pribadi

$\checkmark$ Mengurangi ketidakpastian

$\checkmark$ Berbagi Pengetahuan \& Pengalaman Dgn Orang Lain

c. Komunikasi Publik

$\checkmark$ Menumbuhkan Solidaritas

Mempengaruhi Orang lain

$\checkmark$ Memberi Informasi

$\checkmark$ Mendidik

$\checkmark$ Menghibur

d. Komunikasi Massa

$\checkmark$ Menyebarluaskan Informasi

$\checkmark$ Meratakan Pendidikan

$\checkmark$ Merangsang Pertumbuhan Ekonomi

$\checkmark$ Menciptakan Kegembiraan

$\checkmark$ Menyebarluaskan Informasi

$\checkmark$ Meratakan Pendidikan

$\checkmark$ Merangsang Pertumbuhan Ekonomi

$\checkmark$ Menciptakan Kegembiraan

\section{Rudolph F Verdeber}

a. Fungsi sosial, yakni untuk tujuan kesenangan, untuk menunjukan ikatan dengan orang lain, membangun dan memelihara hubungan

b. Fungsi pengambilan keputusan,yakni memutuskan untuk melakukan atau tidak melakukan sesuatu pada saat tertentu.

Seperti; apa yang kita makan pagi hari, apakah kita akan kuliah atau tidak (keputusan ini dibuat sendiri, dan sebagaian lagi melalui pertimbangan yang matang).

\section{Judy C Pearson dan Paul $£$ Nelson}

1. Fungsi komunikasi untuk kelangsungan hidup diri-sendiri (Keselamatan fisik, meningkatan kesadaran pribadi, menampilkan diri kita sendiri kepada orang lain dan mencapai ambisi pribadi.

2. Untuk kelangsungan hidup masyarakat,tepatnya untuk memperbaiki hubungan sosial dan mengembangkan keberadaan suatu masyarakat.

\section{William I Gorden}


Fungsi Pertama: Komunikasi Sosial

Mengisyaratkan komunikasi penting untuk membangun konsep diri kita, aktualisasi diri, untuk kelangsungan hidup, untuk memperoleh kebahagiaan, terhindar dari tekanan dan ketegangan, antara lain lewat komunikasi yang menghibur. Komunikasilah yang memungkinkan individu membangun suatu kerangka rujukan dan menggunakannya sebagai panduan untuk menafsirkan situasi apa pun yang ia hadapi. Implisit dalam fungsi komunikasi sosial ini adalah fungsi komunikasi cultural. Edward $\mathrm{T}$ Hall, bahwa "budaya adalah komunikasi dan komunikasi adalah budaya. Kematangan dalam budaya ditandai dengan toleransi atas perbedaan, mengutuk orang lain karena mereka berbeda adalah tanda kebebalan dan kecongkakan.

\section{Referensi}

Yulianita, Modul Pembelajaran Mata Kuliah Pengantar Komunikasi. 2008. Surabaya Onong Uchjana.E. Ilmu Komunikasi Teori dan Praktek. Remaja Karya. Bandung 1995. Mulyana.D. Ilmu Komunikasi Suatu Pengantar. PT REMAJA ROSDAKARYA. Bandung. 2007

Suryanto, Pengantar Ilmu Komunikasi.CV PUSTAKA SETIA. 2015.

DevitoA.Joseph. Komunikasi antar manusia, edisi kelima terjemah Hunter College of the city University of New York

HAFIED CANGARA. Pengantar Ilmu Komunikasi. PT RajaGrafido Persada.Depok 2000

Sri Moerdijati. Buku Ajar Pengantar Komunikasi. Revka Petra Media 2012

Vardiansyah. Pengantar Ilmu Komunikasi. Ghalia Indonesia. 2004

Berger, Roloff, Ewoldsen, Handbook Ilmu Komunikasi. Terjemah, Nusa Media 2014

John Fiske. Pengantar Ilmu Komunikasi. PT. Raja Grafindo Persada 2012 


\section{BAB VI}

\section{Komunikasi Verbal Dan Non Verbal}

\section{TUJUAN INSTRUKSIONAL UMUM}

Setelah menyelesaikan materi Bab 6 ini mahasiswa diharapkan mampu:

1. Memahami komunikasi verbal dan non verbal

2. Memahami fungsi komunikasi verbal dan non verbal

\section{TUJUAN INSTRUKSIONAL KHUSUS}

Setelah mempelajari Bab 6 ini mahasiswa diharapkan mampu:

1. Menjelaskan perbedaan komunikasi verbal dan non verbal

2. Menjelaskan kegunaan komunikasi verbal dan non verbal

3. Menjelaskan hambatan-hambatan dalam komunikasi verbal dan nob verbal.

\subsection{S I M B O L}

Simbol adalah satuan komunikasi yang mendasar, berupa kata-kata verbal, ucapan; grafis, tulisan; ataupun lambang seperti pada pusaka dan bendera. Simbol adalah konseptualisasi manusia tentang suatu hal, sebuah simbol ada untuk sesuatu. Lambang memiliki suatu obyek, sedangkan kode atau tanda adalah seperangkat simbol yang telah disusun secara sistematis dan teratur sehingga memiliki arti. Lampu pengatur lalu lintas yang dipasang dipinggir jalan misalnya adalah rambu lalu lintas, sedangkan simbol warna yang telah disusun secara teratur menjadi kode bagi pengguna jalan. Begitu juga halnya dengan letusan senjata misalnya, adalah symbol dari senjata atau ban mobil yang pecah. Tetapi kalau letusan itu berlangsung 21 kali, maka itu adalah kode penghormatan kepada tamu.

Pemberian arti pada simbol adalah suatu proses komunikasi yang dipengaruhi oleh kondisi social budaya yang berkembang pada suatu masyarakat. Karena itu dapat disimpulkan bahwa: 
1. Semua kode memiliki unsur nyata.

2. Semua kode memiliki kode.

3. Semua kode tergantung pada persetujuan para pemakaiannya.

4. Semua kode memiliki fungsi.

5. Semua kode dapat dipindahkan, apakah melalui media atau saluran komunikasi lainnya.

Kode pada dasarnya dapat dibedakan menjadi dua macam, yakni kode verbal (bahasa) non verbal (isyarat). Menururt Dedy Mulyana symbol itu adalah sesuatu yang digunakan untuk menunjukkan sesuatu yang lain. Simbol itu tidak mempunyai arti kitalah yang memberi arti terhadap symbol itu sendiri. Ketika kita mengatakan A maka A sendiri tidak mempunyai arti kitalah yang mengartikan A adalah symbol dari huruf $\mathrm{A}$ melalui kesepakatan bersama.

Ciri utama dari simbol, menurut Hoebel (1966:299) adalah kepadatannya: "Dalam satu bentuk atau lainnya, simbol itu selalu bersifat terbuka, ia harus terlihat, terdengar dirasakan atau dibaui. Simbol-simbol itu memadatkan abstraksi ke dalam objek yang terbatas."

Dalam simbol dapat dibedakan menjadi dua yaitu simbol yang berbentuk bahasa dan simbol yang berbentuk non bahasa atau non verbal. Perbedaan antara simbol, dan tanda adalah sebagai berikut:

1. Tanda memperlihatkan hubungan langsung dengan kenyataan sedangkan simbol memperlihatkan hubungan yang tidak langsung dengan kenyataan.

2. Tanda bersifat terbatas, lambat bertambah, sedangkan simbol berkembang dengan cepat sesuai dengan perkembangan pemikiran penutur bahasa yang bersangkutan.

3. Lambang memanfaatkan bunyi-bunyi bahasa yang dihasilkan oleh alat-alat bicara manusia yang kemudian jika ingin dinyatakan dalam bentuk tertulis, maka lambang tadi menggunakan grafen-grafen tertentu, sedangkan tanda tidak seperti itu.

4. Tanda, meskipun bersifat konvensional tidak dapat diorganisasi, tidak dapat direkam, dan tidak dapat dikomunikasikan seperti simbol.

5. Simbol adalah bagian dan dunia makna manusia.

6. Tanda adalah "operator", simbol adalah "designator". Tanda, bahkan pun bila dipahami dan digunakan seperti itu, bagaimanapun merupakan sesuatu yang fisik dan substansial; simbol hanya memiliki nilai fungsional. 


\subsection{KOMUNIKASI VERBAL}

Yang dimaksud dengan komunikasi verbal adalah komunikasi yang menggunakan symbol-simbol atau kata-kata, baik yang dinyatakan secara oral atau lisan maupun secara tulisan. Komunikasi verbal merupakan karakteristik khusus dari manusia. Kemampuan menggunakan komunikasi verbal secara efektif adalah penting bagi administrator dan manajer. Dengan adanya tujuan komunikasin verbal memungkinkan pengidentifikasikan tujuan, pengembangan strategi dan tingkah laku untuk mencaoai tujuan.

Komunikasi verbal dapat dibedakan atas komunikasi lisan dan komunikasi tulisan. Komunikasi lisan dapat didefinikasikan sebagai suatu proses di mana seseorang berinteraksi secara lisan dengan pendengar untuk mempengaruhi tingkah laku penerima.

Contoh dari komunikasi lisan seperti: intruksi, penjelasan, laporan lisan, pembicaraan untuk mendapatkan persetujuan kebijaksanaan, memajukan penjualan dan sebagainya.

Dalam komunikasi tulisan ada beberapa hal yang perlu diperhatikan. Pertama sekali adalah penampilannya. Penampilan komunikasi adalah hal yang vital. Penampilan pesan sering menentukan apakah pesan itu akan diterima sebagai apa yang dimaksudkan.

Simbol atau pesan verbal adalah semua jenis simbol yang menggunakan satu kata atau lebih. Suatu sistem kode verbal disebut bahasa. Bahasa dapat didefenisikan sebagaiperangkat simbol, dengan aturan untuh mengkombinasikan simbol-simbol tersebut, yang digunakan dan dipahami suatu koinunitas.

Bahasa adalah sebuah sistem simbol-tulisan dan lisan yang digunakan oleh anggota suatu kelompok masyarakat dengan cara yang teratur untuk memperoleh suatu arti. Menurut Krech dalam Santoso (2008), menetapkan 3 fungsi utama bahasa :

1. Bahasa adalah alat utama dalam berkomunikasi

2. Bahasa mencerminkan kepribadian individu dan kebudayaan masyarakat sekaligus

3. Bahasa meningkatkan pertumbuhan dan pewarisan kebudayaan, kelangsungan masyarakat dan fungsi pengawasan 
Bahasa lebih sering digunakan dalan proses komunikasi karena bahasa lebih muda untuk digunakan dalam menyampaikan pikiran-pikiran, ide atau gagasan serta pendapat dalam proses komunikasi.

Bahasa verbal adalah sarana utama untuk menyatakan pikiran, perasaaan, dan maksud kita. Bahasa verbal menggunakan kata-kata yang mempresentasikan berbagai aspek realitas individual kita. Konsekuensinya, kata-kata adalah abstraksi realitas kita yang tidak mampu menimbulkan reaksi yang merupakan totalitas objek atau konsep yang diwakili kata-kata itu. Misalya: kata "rumah" $\longrightarrow$ begitu banyak rumah, ada rumah bertingkat, rumah bilik, rumah sederehana dll.

Komunikasi Verbal mencakup aspek-aspek berupa :

1. Vocabulary (perbendaharaan kata-kata). Komunikasi tidak akan efektif bila pesan disampaikan dengan kata-kata yang tidak dimengerti, karena itu olah kata menjadi penting dalam berkomunikasi.

2. Racing (kecepatan). Komunikasi akan lebih efektif dan sukses bila kecepatan bicara dapat diatur dengan baik, tidak terlalu cepat atau terlalu lambat.

3. Intonasi suara: akan mempengaruhi arti pesan secara dramatik sehingga pesan akan menjadi lain artinya bila diucapkan dengan intonasi suara yang berbeda. Intonasi suara yang tidak proposional merupakan hambatan dalam berkomunikasi.

4. Humor: dapat meningkatkan kehidupan yang bahagia. Dugan (1989), memberikan catatan bahwa dengan tertawa dapat membantu menghilangkan stress dan nyeri. Tertawa mempunyai hubungan fisik dan psikis dan harus diingat bahwa humor adalah merupakan satu-satunya selingan dalam berkomunikasi.

5. Singkat dan jelas. Komunikasi akan efektif bila disampaikan secara singkat dan jelas, langsung pada pokok permasalahannya sehingga lebih mudah dimengerti.

6. Timing (waktu yang tepat) adalah hal kritis yang perlu diperhatikan karena berkomunikasi akan berarti bila seseorang bersedia untuk berkomunikasi, artinya dapat menyediakan waktu untuk mendengar atau memperhatikan apa yang disampaikan.

Asal-Usul Bahasa. Bahasa adalah eksistensi prilaku sosial Peneтиan-peneтиаn fenomena komunikasi:

$>4000$ th SM ditemukan tulisan pada tanah disumeriah dan mesopotamia

$>3000$ th SM ditemukan hurufmesirkuno 
$>1800$ th SM alphabet phunisia

$>600$ th SM huruf latin

$>676 \mathrm{M}$ pemakaian tinta dan kertas di phersia dan eropa (th $1200 \mathrm{M}$ )

> 1271 marcopolo berpetualang dari venesia menuju tembok china perlu waktu 4 tahun untuk berjalan kaki

$>1450$ ditemukan teknik cetak mencetak yang dianggap sebagai awal revolusi Mormasi

\subsection{FUNGSI BAHASA DALAM KEHIDUPAN MANUSIA}

Kita sering tidak menyadari pentingnya bahasa, kerena kita sepanjang hidup menggunakannya. Kita baru sadar bahasa itu penting ketika kita menemui jalan buntu dalam menggunakan bahasa. Misalnya, ketika kita berupaya berkomunikasi dengan orang yang sama sekali tidak memahami bahasa kita yang membuat kita frustasi, ketika kita sulit menerjemahkan suatu kata, frase, atau kalimat dari suatu bahasa ke bahasa lain. Fungsi bahasa yang mendasar adalah untuk menamai atau menjuluki orang, obyek dan peristiwa.

Penamaan adalah dimensi pertama bahasa dan basis bahasa, dan pada awalnya itu dilakukan manusia sesuka mereka yang lalu menjadi konvensi. Misalnya, benda yang kita terima dari tukang pos kita sebut surat ketika isinya kita ketahui menawarkan barang atau jasa disebut iklan, karena kita tidak tertarik pada penawaran itu, benda itu kita buang ke keranjang sampah, dan barang itu kita sebut sampah.

Menurut Larry L Barker, bahasa memiliki tiga fungsi:

1) Penamaan (naming atau labeling). Melalui bahasa memungkinkan kita memikirkan, membicarakan dan mengantisipasi massa depan.

2) Interaksi. Bahasa memungkinkan kita dapat bergaul dengan orang lain untuk mencapai tujuan kita, melalui bahasa kita juga dapat mengendalikan lingkungan kita, termasuk orang-orang disekitar kita. Kemampuan berkomunikasi dengan orang lain bergantung tidak hanya pada bahasa yang sama, namun juga pengalaman yang sama dan makna yang sama kita berikan kepada kata-kata dalam bahasa.

3) Transmisi informasi. Bahasa memungkinkan kita untuk hidup lebih teratur, saling memahami mengenai diri kita, kepercayaan-kepercayaan kita, dan tujuan kita. Tanpa bahasa kita tidak mungkin bertukar informasi. Jadi bahasa merupakan sarana penting dalam membagi informasi atau pesan.

Kerumitan Makna Kata. Apakah kata mempunyai makna? Sebenarnya kita keliru bila kita mengangap bahwa kata-kata itu mempunyai makna, kitalah yang 
memberi makna pada kata, dan makna yang kita berikan kepada kata yang sama bisa berbeda - beda, bergantung pada konteks ruang dan waktu. Makna tidak melekat pada kata-kata, namun kata-kata membangkitkan makna dalam pikiran orang. Makna dapat pula digolongkan kedalam: makna denotatif dan makna konotatif.

Makna denotatif adalah makna yang sebenarnya (faktual), seperti yang kita temukan dalam kamus dan bersifat publik. Contoh "kursi Bupati sedang digoyang" Maksudnya yang digoyang benar-benar kursi bupati.

Makna konotatif, lebih bersifat pribadi, yakni makna diluar rujukan objektifnya. Misal kata "kursi Bupati sedang digoyang" Maksudnya adalah kursi diartikan kekuasaan Bupati sedang dipermasalahkan atau di perebutkan. Contoh lain misalnya pramuniaga dan pelayan toko, kita merasa pramuniaga lebih bergengsi daripada pelayan toko.

Nama Sebagai Simbol. Seperti yang kita bahas di atas, dimensi pertama atau fungsi pertama bahasa adalah penamaan, Nama pribadi adalah unsur penting identitas seseorang dalam masyarakat, karena interaksi dimulai dengan nama dan baru kemudian diikuti dengan atribut-atribut lainya. Nama yang kita terima sejak lahir tidak hanya mempengaruhi kehidupan kita dalam mempersepsi diri-sendiri. Misalnya: julukan "murahan" terhadap seorang wanita mempengaruhi bagaimana orang itu diperlakukan oleh lawan jenisnya, pendeknya nama dapat mempengaruhi hidup anda.

\subsection{KOMUNIKASI NON VERBAL}

Komunikasi nonverbal adalah proses komunikasi dimana pesan disampaikan tidak menggunakan kata-kata. Contoh komunikasi nonverbal ialah menggunakan gerak isyarat, bahasa tubuh, ekspresi wajah dan kontak mata, penggunaan objek seperti pakaian, potongan rambut, dan sebagainya, simbol-simbol, serta cara berbicara seperti intonasi, penekanan, kualitas suara, gaya emosi, dan gaya berbicara. Menurut Larry A. Samofar dan Richard E. Potter - Komunikasi nonverbal mencakup semua rangsangan (kecuali rangsangan verbal).

$>$ Isyarat nonverbal juga tidak universal melainkan terikat oleh budaya, jadi dipelajari, bukan bawaan.

$>$ Perilaku nonverbal bersifat spontan, ambigu, sering berlangsung cepat

Edward T. Hall - bahasa non verbal ini sebagai bahasa diam (silent language), dimensi tersembunyi (hidden dimension). Bahasa nonverbal sebangun dengan bahasa verbalnya.Pada dasarnya suatu kelompok yang punya bahasa verbal khas juga 
dilengkapi dengan bahasa nonverbal khas, yang sejajar dengan bahasa verbal tersebut. Perbedaan komunikasi verbal dengan komunikasi nonverbal

1. Perilaku verbal - saluran tunggal

Perilaku nonverbal - multisaluran (terus belangsung)

2. Pesan verbal - terpisah

Pesan nonverbal - sinambung (tetap berjalan)

3. Komunikasi nonverbal mengandung lebih banyak muatan emosional dari pada komunikasi verbal

Simbol non verbal adalah simbol yang bukan berasal dari bahasa dan tulisan. Simbol nonverbal biasa disebut bahasa isyarat atau bahasa diam. Hal menarik dari simbol nonverbal adalah studi Albert Mahrabian (1971) yang menyimpulkan bahwa tingkat kepercayaan dari pembicara orang hanya 7 persen berasal dari bahasa verbal, 38 persen dari vocal suara dan 55 persen dari ekspresi muka. Ia juga menambahkan bahwa jika terjadi pertentangan antara apa yang diucapkan seseorang dengan perbuatannya, maka orang lain akan cenderung mempercayai hal-hal yang bersifat nonverbal. Oleh sebab itu, Mark Knapp (1978) menyebut bahwa penggunaan kode nonverbal dalam berkomunikasi memiliki fungsi untuk :

- Menyakinkan apa yang diucapkannya.

- Menunjukkan perasaan dan emosi yang tidak bisa diutarakan dengan kata-kata.

- Menunjukkan jati diri sehingga orang lain bisa mengenalnya.

- Menambah atau melengkapi ucapan-ucapan yang dirasakan belum sempurna.

Dari berbagai studi yang pernah dilakukan sebelumnya, kode nonverbal dapat dikelompokkan dalam berbagai bentuk, antara lain:

a. Kinesis ialah kode nonverbal yang ditunjukkan oleh gerakan-gerakan badan.

Gerakan-gerakan badan dapat dibedakan atas lima macam yaitu;

- Emblems adalah syarat yang punya arti langsung pada symbol yang dibuat oleh berakan badan.

- Illustrator adalah isyarat yang dibuat dengan gerakan-gerakan badan untuk menjelaskan sesuatu, misalnya besarnya barang atau tinggi rendahnya suatu obyek yang dibicarakan.

- Affect displays adalah isyarat yang terjadi karena adanya dorongan emosional sehingga berpengaruh pada ekspresi muka, misalnya tertawa, menangis, tersenyum, dsb. Hamper semua bangsa di dunia melihat perilaku ini.

- Regulators adalah gerakan-gerakan tubuh yang terjadi pada daerah kepala. 
- Adaptory adalah gerakan badan yang dilakukan sebagai tanda kejengkelan. misalnya mengerutu.

b. Gerakan Mata (eyes gaze) Mata adalah alat komunikasi yang paling berarti dalam memberi isyarat tanpa kata. Ungkapan "pandangan mata mengundang” atau lirikan matanya memiliki arti adalah isyarat yang ditimbulkan oleh gerakan-gerakan mata. Bahwa ada yang menilai bahwa gerakan mata adalah pencerminan isi hati seseorang.

- Kontak mata, merupakan sinyal alamiah untuk berkomunikasi. Dengan mengadakan kontak mata selama berinterakasi atau tanya jawab berarti orang tersebut terlibat dan menghargai lawan bicaranya dengan kemauan untuk memperhatikan bukan sekedar mendengarkan. Melalui kontak mata juga memberikan kesempatan pada orang lain untuk mengobservasi yang lainnya.

c. Sentuhan. Sentuhan adalah bentuk komunikasi personal mengingat sentuhan lebih bersifat spontan dari pada komunikasi verbal. Beberapa pesan seperti perhatian yang sungguh-sungguh, dukungan emosional, kasih sayang atau simpati dapat dilakukan melalui sentuhan. Menurut bentuknya sentuhan badan dibedakan menjadi tiga macam, yaitu:

- Kinesthetic adalah isyarat yang ditunjukkan dengan bergandengan tangan satu sama lain, sebagai symbol keakraban atau kemesraan.

- Sosiofugal ialah isyarat yang ditunjukkan dengan jabat tangan atau saling merangkul.

- Thermal adalah isyarat yang ditunjukkan dengan sentuhan badan yang terlalu emosional sebagai tanda persahabatan yang begitu intim.

d. Paralanguage ialah isyarat yang ditimbulkan dari tekanan atau irama suara sehingga penerima dapat memahami sesuatu dibalik apa yang diucapkan. Suatu kesalahpahaman seringkali terjadi kalau komunikasi berlangsung dari etnik yang berbeda. Suara yang tekanan besar bisa di salah artikan oleh etnik tertentu sebagai perlakuan kasar, meski menurut kata hatinya tidak demikian.

e. Diam. Bahwa diam tidak semata-mata mengandung arti bersikap negative, tetapi juga melambangkan sikap positif. Diam adalah perilaku komunikasi sekarang ini makin banyak dilakukan oleh orang-orang yang bersikap netral dan mau aman.

f. Postur Tubuh dan gaya berjalan. Cara seseorang berjalan, duduk, berdiri dan bergerak memperlihatkan ekspresi dirinya. Postur tubuh dan gaya berjalan merefleksikan emosi, konsep diri, dan tingkat kesehatannya Pada tubuh yang bertipe ectomorphy (kurus tinggi) dilambangkan orang yang memiliki sikap yang ambisi, 
pintar, kritis, dan sedikit cemas. Jika mesomorphy (tegap, yinggi \& atletis) dilambangkan sebagai pribadi yang cerdas, bersahabat, aktif dan kompetitif. Jika endomorphy (pendek, bulat dan gemuk) digambarka sebagai pribadi yang humoris, santai, dan cerdik.

g. Kedekatan dan Ruang (proximity and spatial). Proximity adalah kode nonverbal yang menunjukkan kedekatan dari dua obyek yang mengandung arti. Proximity dapat dibedakan atas teritory atau zone. Edward T Hall (1959) membagi kedekaatan menurut teritory atas empat macam, yakni:

- Wilayah intim (rahasia), yaitu kedekatan yang berjarak antara 3-18 inchi.

- Wilayah pribadi, yaitu kedekatan yang berjarak antara 18 inchi hingga 4 kaki.

- Wilayah social, yaitu kedekatan yang berjarak antara 4-12 kaki.

- Wilayah umum, yaitu kedekatan yang berjarak antara 4-12 kaki.

h. Artifak dan Visualisasi. Artifak adalah kerajinan manusia (seni), baik yang melekat pada diri manusia maupun yang ditunjukkan untuk kepentingan umum dan artifak juga dapat menunjukkan status atau identitas seseorang. Misalnya bju, perhiasan dsb.

i. Warna. Warna juga memberi arti terhadap suatu obyek.

j. Waktu. Bahwa waktu sangat penting bagi orang yang ingin maju, waktu memiliki arti tersendiri dalam kehidupan manusia.

k. Sound (Suara). Kalau paralanguage dimaksudkan sebagai tekanan suara yang keluar dari mulut untuk menjelaskan ucapan verbal, maka banyak bunyi-bunyian yang dilakukan sebagai tanda isyarat yang tidak dapat digolongkan sebagai paralanguage. Misalnya bersiul, bertepuk tangan dsb. Bunyi-bunyian seperti ini dimaksudkan untuk mengatasi jarak yang jauh dan menyatakan perintah untuk kelompok orang yang banyak. Rintihan, menarik nafas panjang, tangisan juga salah satu ungkapan perasaan dan pikiran seseorang yang dapat dijadikan komunikasi. Bila dikombinasikan dengan semua bentuk komunikasi non verbal lainnya sampai desis atau suara dapat menjadi pesan yang sangat jelas.

1. Bau. Selain digunakan sebagai status seperti kosmetik, bau juga digunakan sebagai petunjuk arah. Misalnya bau bangkai bisa diindikasikan adanya mayat.

\section{Fungsi-Fungsi Pesan Nonverbal}

1. Repetisi : Mengulang kembali gagasan yang sudah disajikan secara verbal.

2. Substitusi : Menggantikan lambing-lambang verbal.

3. Kontradiksi : Menolak pesan verbal atau memberikan makna yang berbeda dengan pesan verbal. 
4. Komplemen : Melengkapi dan memperkaya makna pesan verbal.

5. Aksentuasi : Menegaskan pesan verbal atau menggarisbawahinya.

6. Gerak isyarat : adalah yang dapat mempertegas pembicaraan . Menggunakan isyarat sebagai bagian total dari komunikasi seperti mengetuk-ngetukan kaki atau mengerakkan tangan selama berbicara menunjukkan seseorang dalam keadaan stress bingung atau sebagai upaya untuk menghilangkan stress

\section{Pesan Nonverbal Penting Karena:}

1. Faktor-faktor nonverbal sangat menentukan makna dalam komunikasi antarpersona.

2. Perasaan dan emosi lebih tepat disampaikan lewat pesan nonverbal daripada pesan verbal.

3. Pesan nonverbal menyampaikan makna dan maksud yang relative bebes dari penipuan, distorsi dan kerancuan.

4. Pesan nonverbal mempunyai fungsi metakomunikatif yang sangat diperlukan untuk mencapai komunikasi yang berkualitas tinggi.

5. Pesan nonverbal merupakan cara komunikasi yang lebih efisien disbanding pesan verbal.

6. Pesan nonverbal merupakan sarana sugesti yang paling tepat.

7. Metakomunikatif: memberikan informasi tambahan yang memper jelas makna dan maksud peran.

\section{Fungsi Komunikasi Nonverbal}

1. Perilaku nonverbal dapat mengulangi perilaku verbal

2. Memperteguh, menekankan / melengkapi perilaku verbal

3. Perilaku nonveral dapat meregulasi perilaku verbal

4. Perilaku nonverbal dapat membantah atau bertentangan dengan perilaku perilaku verbal. 


\section{Referensi}

Mulyana.D. Ilmu Komunikasi Suatu Pengantar. PT REMAJA ROSDAKARYA. Bandung. 2007

Onong Uchjana.E. Ilmu Komunikasi Teori dan Praktek. Remaja Karya. Bandung 1995

REED H.BLAKE AND EDWIN O. HAROLDSEN, A.Taxonomy of concepts in Communication, HASTING HOUSE.PUBLISHERS. 1979

Roudhonah, Ilmu Komunikasi. PT RajaGrafido Persada.Depok 2000

DevitoA.Joseph. Komunikasi antar manusia, edisi kelima terjemah Hunter College of the city University of New York

Berger, Roloff, Ewoldsen, Handbook Ilmu Komunikasi. Terjemah, Nusa Media 2014

Vardiansyah. Pengantar Ilmu Komunikasi. Ghalia Indonesia. 2004

John Fiske. Pengantar Ilmu Komunikasi. PT. Raja Grafindo Persada 2012 


\section{BAB VII \\ Komunikasi Intra Pribadi}

\section{TUJUAN INSTRUKSIONAL UMUM}

Setelah menyelesaikan materi Bab 7 ini mahasiswa diharapkan mampu:

1. Memahami tentang tujuan dan fungsi komunikasi intra pribadi

2. Memahami aplikasi dari komunikasi intra pribadi dalam kehidupan sehari-hari

\section{TUJUAN INSTRUKSIONAL KHUSUS}

Setelah mempelajari materi Bab 7 ini mahasiswa diharapkan mampu:

1. Menjelaskan tujuan dan fungsi komunikasi intra pribadi

2. Mendiskusikan tujuan dan fungsi komunikasi intra pribadi dalam kehidupan seharihari

\subsection{TAHAPAN-TAHAPAN KOMUNIKASI INTRA PRIBADI}

Komunikasi intrapribadi adalah peristiwa komunikasi yang terjadi dalam diri pribadi seseorang. Jelasnya, seseorang berbicara kepada dirinya sendiri. Dimungkinkan terjadi karena manusia dapat menjadi objek bagi dirinya sendiri melalui penggunaan simbol-simbol yang digunakan dalam komunikasinya. Setiap manusia pasti melakukan komunikasi dengan dirinya sendiri walaupun sering tidak disadarinya. Hampir setiap saat ketika manusia ingin mengambil keputusan dan tindakan tidak luput dari proses komunikasi intrapersonal atau intrapribadi.

Komunikasi intrapersonal merupakan keterlibatan internal secara aktif dari individu dalam pemrosesan simbolik dari pesan-pesan. Seorang individu menjadi pengirim sekaligus penerima pesan, memberikan umpan balik bagi dirinya sendiri dalam proses internal yang berkelanjutan. Dalam Proses Komunikasi intrapersonal, seorang komunikator melakukan pengolahan informasi yang ia peroleh, hingga menjadi pesan yang ia pahami dan diberikan makna. Menurut Rakhmat (2009), proses 
komunikasi intrapersonal melalui empat tahapan, yaitu; sensasi, persepsi, memori, dan berpikir.

Adapun penjelasan dari tahapan-tahapan komunikasi intrapersonal adalah sebagai berikut:

\section{Sensasi}

Tahap pertama dalam penerimaan informasi ialah sensasi. Sensasi berasal dari kata sense, artinya alat pengindraan, yang menghubungkan organisme dengan lingkungannya. Sensasi adalah kemampuan yang memiliki manusia untuk menyerap segala hal yang diinformasikan oleh pancaindra. Informasi yang diserap oleh pancaindra disebut stimulus yang kemudian melahirkan proses sensasi.

Dengan demikian sensasi adalah menangkap stimulus. Sensasi merupakan pengalaman elementer segera yang tidak memerlukan penguraian verbal, simbolis atau konseptual, dan terutama berhubungan dengan kegiatan alat indra. Apa saja yang menyentuh alat indra, dari dalam atau dari luar disebut stimuli. Stimuli yang diterima oleh alat indra diubah menjadi energi syaraf untuk disampaikan ke otak melalui proses transduksi. Stimuli harus cukup kuat agar dapat diterima oleh alat indra.

Ketajaman sensasi juga dipengaruhi oleh oleh faktor-faktor personal. Misalnya, masakan padang yang dirasa pedas bagi orang Jawa, ternyata dirasa biasa-biasa saja bagi orang Sumatra Barat. Perbedaan sensasi, dengan begitu dapat disebabkan oleh perbedaan pengalaman atau lingkungan budaya, di samping kapasitas alat indra yang berbeda. Perbedaan kapasitas alat indra menyebabkan perbedaan seseorang ketika memilih mendengarkan musik atau memutar audio. Yang jelas, sensasi mempengaruhi persepsi.

\section{Persepsi}

Persepsi adalah pengalaman tentang objek, peristiwa, atau hubungan-hubungan yang diperoleh dengan menyimpulkan informasi dan menafsirkan pesan. Persepsi ialah memberikan makna pada stimuli indrawi (sensory stimuli). Hubungan sensasi dengan persepsi adalah sensasi merupakan bagian dari persepsi. Persepsi dipengaruhi oleh sensasi yang merupakan hasil serapan panca indra, persepsi juga dipengaruhi oleh perhatian (attention), harapan (expectation), motivasi dan ingatan.

Seperti sensasi, persepsi juga dipengaruhi oleh beberapa faktor. Salah satu faktor yang sangat mempengaruhi persepsi yaitu perhatian. Perhatian adalah proses mental ketika stimuli menjadi menonjol dalam kesadaran pada saat stimuli lainnya melemah. 
Perhatian terjadi apabila kita konsen terhadap salah satu indra dan mengesampingkan stimuli dari indra yang lain. Perhatian yang kita tujukan terhadap sesuatu dipengaruhi oleh banyak faktor eksternal penarik perhatian adalah sebagai berikut :

a. Gerakan. Manusia secara virtual tertarik pada objek-objek yang bergerak. Misalnya, wallpaper atau screensaver yang bergerak seperti animasi dalam smartphone akan terlihat lebih menarik dibandingkan yang tidak bergerak. Seperti juga iklan ditelevisi lebih terlihat menarik dari iklan koran karena terlihat lebih hidup.

b. Intensitas stimuli. Kita akan memperhatikan stimuli yang lebih menonjol dari stimuli yang lain. Sesuatu yang berbeda dari yang lain akan merebut perhatian orang. Misalnya suara keras di perpustakaan, warna kuning pada latar belakang hitam, diskon besar-besaran di pusat perbelanjaan, atau poster yang berjejeran di tembok pinggir jalan.

c. Kebaruan (Novelty). Hal-hal yang baru dan luar biasa akan mampu menarik perhatian. Beberapa eksperimen membuktikan bahwa stimuli yang luar biasa lebih mudah dipelajari dan diingat. Misalnya film dan novel baru yang sering diburu, smartphone atau kendaraan dengan teknologi baru, dan lain sebagainya. Tanpa hal yang baru, stimuli menjadi monoton, membosankan, dan lepas dari perhatian.

d. Perulangan. Hal-hal yang disajikan berulang kali, bila disertai dengan variasi akan menarik perhatian. Perulangan juga mengandung unsur sugesti yakni mempengaruhi alam bawah sadar kita. Yang paling sering kita lihat sebagai contoh perulangan adalah iklan. Produk yang sama namun diiklankan berulangulang. Terkadang diberi variasi, untuk iklan selanjutnya namun masih dengan produk yang sama. Politisi juga sering melakukan perulangan untuk slogan-slogan yang menggambarkan dirinya agar menarik perhatian massa.

Faktor internal perhatian terbagi menjadi faktor biologis dan sosiopsikologis. Adapun penjelasan dari faktor tersebut adalah sebagai berikut:

a. Faktor Bilologis. Hal-hal yang sifatnya biologis mempengaruhi perhatian kita. Misalnya ketika seseorang lapar, maka yang menarik perhatiannya adalah makanan. Hal ini berangkat dari dalam diri seseorang, dari apa yang dirasakan, sehingga mampu mempengaruhinya.

b. Faktor Sosiopsikologis. Seperti motif, sikap, kebiasaan, dan kemauan. Dalam perjalanan naik gunung misalnya, seorang ahli geolog akan memperhatikan 
batuan, ahli botani akan memperhatikan bunga-bungaan, dan ahli zoologi akan memperhatikan bintang.

\section{Memori}

Dalam komunikasi intrapersonal, memori memegang peranan penting dalam mempengaruhi baik persepsi (dengan menyediakan kerangka rujukan) maupun berpikir. Memori adalah sistem yang sangat terstruktur, yang menyebabkan organisme sanggup merekam fakta tentang dunia dan menggunakan pengetahuannya untuk membimbing perilakunya. Setiap stimuli datang, stimuli itu direkam sadar atau tidak. Kapasitas memori manusia diciptakan sangat besar namun hanya sedikit orang yang mampu menggunakan memorinya sepenuhnya, bahkan Einstein yang tercatat manusia paling genius baru mengoperasikan $15 \%$ dari memorinya.

Sesuatu yang sudah tersimpan dalam memori akan mempengaruhi pemaknaan/persepsi seseorang terhadap sesuatu di waktu yang lain. Begitu pun dalam berpikir, untuk memutuskan/memerintahkan sesuatu, seseorang akan membuka memorinya untuk mengetahui apa yang perlu dipertimbangkan dalam memutuskan sesuatu, atau siapa yang perlu diperintah untuk melakukan sesuatu tersebut. Sehingga memori memiliki peranan penting bagi individu dalam menentukan persepsi dan berpikir.

Proses kerja memori melewati tiga proses, yaitu perekaman, penyimpanan dan pemanggilan. Perekaman (encoding) adalah pencatatan informasi melalui reseptor indra dan sirkit syaraf internal. Penyimpanan (storage) adalah menentukan berapa lama informasi itu berada beserta kita, dalam bentuk apa dan dimana. Penyimpanan bisa aktif dan pasif. Penyimpanan aktif terjadi apabila kita menambah informasi. Pemanggilan (retrieval), adalah mengingat lagi atau menggunakan informasi yang disimpan.

\section{Berpikir}

Berpikir merupakan manipulasi atau organisasi unsur-unsur lingkungan dengan menggunakan lambang-lambang sehingga tidak perlu langsung melakukan kegiatan yang tampak. Dalam berpikir kita akan melibatkan semua proses yang kita sebut di atas yaitu, sensasi, berpikir, dan memori. Saat berpikir maka memerlukan penggunaan lambang, visual atau grafis. Berpikir dilakukan untuk memahami realitas dalam rangka mengambil keputusan, memecahkan persoalan, dan menghasilkan yang baru.

Secara garis besar, terdapat dua macam berpikir: berpikir autistik dan berpikir realistis. Berpikir autistik contohnya melamun, mengkhayal, dan berfantasi. Sedangkan 
berpikir realistis disebut juga berpikir nalar ialah berpikir dalam rangka menyesuaikan diri dengan dunia nyata. Berpikir realistis terbagi dalam tiga jenis, yaitu; deduktif, induktif, dan evaluatif.

Berpikir deduktif ialah mengambil kesimpulan dari dua pernyataan yang dimulai dengan pernyataan umum. Sebaliknya, berpikir induktif ialah mengambil kesimpulan dari hal-hal yang khusus dan kemudian mengambil kesimpulan umum atau generalisasi. Sedangkan berpikir evaluatif ialah berpikir kritis, menilai baik-buruknya sesuatu. Dalam berpikir evaluatif kita tidak menambah atau mengurangi sesuatu/gagasan, namun menilainya menurut kriteria tertentu.

\subsection{FAKTOR YANG MEMPENGARUHI KOMUNIKASI INTRAPERSONAL}

Menurut Potter dan Perry (1997), terdapat beberapa faktor yang mempengaruhi kemampuan komunikasi intrapersonal seseorang, antara lain yaitu :

1. Perkembangan. Tingkat perkembangan dalam berbicara bervariasi dan hal ini berhubungan erat dengan perkembangan anak. Orang tua memberikan pengaruh penting terhadap kemampuan anak untuk berkomunikasi. Perkembangan pada individu menentukan jenis komunikasi apa yang akan dipilih.

2. Nilai. Nilai dapat mempengaruhi interpretasi pesan dan juga bagaimana individu menginterpretasikan ide yang datang dari orang lain. Jika nilai yang dimilik seseorang berbeda dan tidak ada penyesuaian antar individu kemungkinan akan terjadi konflik saat melakukan komunikasi.

3. Emosi. Emosi dapat membuat seseorang salah menginterpretasikan pesan yang diterima. Jika emosi mempengaruhi komunikasi dimaknai sebagai perasaan subjektif seseorang dan mempengaruhi individu bagaimana berinteraksi dengan seseorang. Jika pada seseorang yang berkomunikasi tidak terkontrol emosinya maka akan terjadi perdebatan karena emosi yang muncul.

4. Latar belakang sosiokultural. Budaya adalah hasil dari mempelajari cara berbuat, berpikir, dan merasakan. Pengaruh kebudayaan menetapkan batas bagaimana seseorang bertindak dan berkomunikasi, dalam hal ini komunikator harus bisa menyesuaikan dengan kebudayaan komunikan agar komunikasi yang berjalan menjadi efektif.

5. Gender. Pria dan wanita memiliki cara berkomunikasi yang berbeda-beda. Anak perempuan biasanya perkembangan pusat komunikasi di otaknya lebih bagus dari pada laki-laki. 
6. Pengetahuan. Penggunaan bahasa yang umum sangat tepat digunakan jika pengirim dan penerima pesan memiliki tingkat pengetahuan yang berbeda. Pesan akan menjadi tidak jelas jika kata yang digunakan tidak dikenal penerima. Karena pemakaian bahasa yang lazim menjadi faktor yang sangat membantu dalam berkomunikasi untuk menjembatani perbedaan yang terjadi.

7. Lingkungan. Seseorang dapat berkomunikasi lebih baik dalam lingkungan yang nyaman. Kurangnya kebebasan seseorang bisa mengakibatkan kebingungan, ketegangan. Gangguan lingkungan juga bisa mengganggu pesan yang dikirim. Lingkungan yang nyaman sangat membantu dalam proses komunikasi, karena inilah lingkungan menjadi faktor yang berpengaruh dalam komunikasi.

\section{Referensi}

Berger, Roloff, Ewoldsen, Handbook Ilmu Komunikasi. Terjemah, Nusa Media 2014 Hardjana.A. Komunikasi Organisasi. PT.RAJAGRAFINDO PERSADA. 2019.

Hardjana AM. Komunikasi Intrapersonal dan Interpersonal. Kanisius Yogyakarta. 2003 Suranto. Komunikasi Interpersonal. Graha Ilmu. Yogyakarta. 2011

Stephen W. Littlejohn, Theories of Human Communiation, Wadsworth Publication, New Jersey, 1996.

Mulyana.D. Ilmu Komunikasi Suatu Pengantar. PT REMAJA ROSDAKARYA. Bandung. 2007

Onong Uchjana.E. Ilmu Komunikasi Teori dan Praktek. Remaja Karya. Bandung 1995 REED H.BLAKE AND EDWIN O. HAROLDSEN, A.Taxonomy of concepts in Communication, HASTING HOUSE.PUBLISHERS. 1979

Onong Uchjana.E. Dinamika Komunikasi.Remaja Karya CV. Bandung. 1986

Vardiansyah. Pengantar Ilmu Komunikasi. Ghalia Indonesia. 2004

John Fiske. Pengantar Ilmu Komunikasi. PT. Raja Grafindo Persada 2012 


\section{BAB VIII}

\section{Komunikasi Antar Pribadi}

\section{TUJUAN INSTRUKSIONAL UMUM}

Setelah menyelesaikan materi Bab 8 ini mahasiswa diharapkan mampu:

1. Memahami tentang tujuan dan fungsi komunikasi antar pribadi

2. Memahami aplikasi dari komunikasi antar pribadi dalam kehidupan sehari-hari

\section{TUJUAN INSTRUKSIONAL KHUSUS}

Setelah mempelajari materi Bab 8 ini mahasiswa diharapkan mampu:

1. Menjelaskan tujuan dan fungsi komunikasi antar pribadi

2. Mendiskusikan tujuan dan fungsi komunikasi antar pribadi dalam kehidupan seharihari

\subsection{KOMUNIKASI ANTAR PRIBADI}

Komunikasi antar pribadi (interpersonal communication) adalah komunikasi antara individu-individu (Littlejohn, 1999). Bentuk khusus dari komunikasi antarpribadi ini adalah komunikasi diadik yang melibatkan hanya dua orang secara tatap-muka, yang memungkinkan setiap pesertanya menangkap reaksi orang lain secara langsung, baik secara verbal ataupun nonverbal, seperti suami-isteri, dua sejawat, dua sahabat dekat, seorang guru dengan seorang muridnya, dan sebagainya. Steward L. Tubbs dan Sylvia Moss (dalam Deddy Mulyana, 2005) mengatakan ciri-ciri komunikasi diadik adalah:

1. Peserta komunikasi berada dalam jarak yang dekat

2. Peserta komunikasi mengirim dan menerima pesan secara simultan dan spontan, baik secara verbal maupun nonverbal.

\subsubsection{Pengertian Komunikasi Antarpribadi}

Secara umum komunikasi antar pribadi (KAP) dapat diartikan sebagai suatu proses pertukaran makna antara orang-orang yang saling berkomunikasi. Komunikasi terjadi secara tatap muka (face to face) antara dua individu. Dalam pengertian tersebut mengandung 3 aspek: 
1. Pengertian proses, yaitu mengacu pada perubahan dan tindakan yang berlangsung terus menerus.

2. KAP merupakan suatu pertukaran, yaitu tindakan menyampaikan dan menerima pesan secara timbal balik.

3. Mengandung makna, yaitu sesuatu yang dipertukarkan dalam proses tersebut, adalah kesamaan pemahaman diantara orang-orang yang berkomunikasi terhadap pesan-pesan yang digunakan dalam proses komunikasi.

Dari ketiga aspek tersebut maka KAP menurut Judy C. Pearson memiliki karakteristik sebagai berikut:

1. KAP dimulai dengan diri pribadi (self). Berbagai persepsi komunikasi yang menyangkut pemaknaan berpusat pada diri kita, artinya dipengaruhi oleh pengalaman dan pengamatan kita.

2. KAP bersifat transaksional. Anggapan ini mengacu pada pihak-pihak yang berkomunikasi secara serempak dan bersifat sejajar, menyampaikan dan menerima pesan.

3. KAP mencakup aspek-aspek isi pesan dan hubungan antarpribadi. Artinya isi pesan dipengaruhi oleh hubungan antar pihak yang berkomunikasi.

4. Komunikasi antarpribadi mensyaratkan kedekatan fisik antar pihak yang berkomunikasi.

5. KAP melibatkan pihak-pihak yang saling bergantung satu sama lainnya dalam proses komunikasi.

6. KAP tidak dapat diubah maupun diulang. Jika kita salah mengucapkan sesuatu pada pasangan maka tidak dapat diubah. Bisa memaafkan tapi tidak bisa melupakan atau menghapus yang sudah dikatakan.

KAP berlangsung antar dua individu, karenanya pemahaman komunikasi dan hubungan antar pribadi menempatkan pemahaman mengenai komunikasi dalam proses psikologis. Setiap individu dalam tindakan komunikasi memiliki pemahaman dan makna pribadi terhadap setiap hubungan dimana dia terlibat di dalamnya. Hal terpenting dari aspek psikologis dalam komunikasi adalah asumsi bahwa diri pribadi individu terletak dalam diri individu dan tidak mungkin diamati secara langsung. Artinya dalam KAP pengamatan terhadap seseorang dilakukan melalui perilakunya dengan mendasarkan pada persespsi si pengamat. Dengan demikian aspek psikologis mencakup pengamatan pada dua dimensi, yaitu internal dan eksternal. Namun kita mengetahui bahwa dimensi eksternal tidaklah selalu sama dengan dimensi internalnya. 
Fungsi psikologis dari komunikasi adalah untuk menginterpretasikan tandatanda melalui tindakan atau perilaku yang dapat diamati. Proses interpretasi ini setiap individu berbeda. Karena setiap individu memiliki kepribadian yang berbeda, yang terbentuk karena pengalaman yang berbeda pula. Faktor-faktor yang mem pengaruhi individu dalam KAP Sebagaimana telah disinggung di atas bahwa komunikasi antarpribadi dimulai dari diri individu. Tampilan komunikasi yang muncul dalam setiap kita berkomunikasi mencerminkan kepribadian dari setiap individu yang berkomunikasi. Pemahaman terhadap proses pembentukan keperibadian setiap pihak yang terlibat dalam komunikasi menjadi penting dan mempengaruhi keberhasilan komunikasi.

Dalam sudut pandang psikologis KAP merupakan kegiatan yang melibatkan dua orang atau lebih yang memiliki tingkat kesamaan diri. Saat dua orang berkomunikasi maka keduanya harus memiliki kesamaan tertentu, katakanlah laki-laki dan perempuan. Mereka secara individual dan serempak memperluas diri pribadi masing-masing ke dalam tindakan komunikasi melalui pemikiran, perasaan, keyakinan, atau dengan kata lain melalui proses psikologis mereka. Proses ini berlangsung terus menerus sepanjang keduanya masih terlibat dalam tindak komunikasi.Saling berbagi pengalaman tidaklah berarti memiliki kesamaan pemahaman atau kesamaan diri yang tunggal tetapi bisa merupakan persinggungan dan sejumlah perbedaan. Fisher mengemukakan bahwa ketika kita berkomunikasi dengan orang lain, proses intrapribadi kita memiliki paling sedikit tiga tataran yang berbeda. Tiap tataran tersebut akan berkaitan dengan sejumlah yang hadir dalam situasi antar pribadi, yaitu pandangan kita mengenai diri sendiri, pandangan kita mengenai diri orang lain, dan pandangan kita mengenai pandangan orang lain tentang kita.

Pentingnya proses psikologis hendaknya dipahami secara cermat, artinya proses intrapribadi dari partisipan komunikasi bukanlah hal yang sama dengan hubungan antarpribadi. Apa yang terjadi dalam diri individu bukanlah komunikasi antarpribadi melainkan proses psikologis. Meskipun demikian proses psikologis dari tiap individu pasti mempengaruhi komunikasi antar pribadi yang pada gilirannya juga mempengaruhi hubungan antarpribadi.

Komunikasi antarpribadi sangat potensial untuk menjalankan fungsi instrumental sebagai alat untuk mempengaruhi atau membujuk orang lain, karena kita dapat menggunakan kelima lat indera kita untuk mempertinggi daya bujuk pesan yang kita komunikasikan kepada komunikan kita. Sebagai komunikasi yang paling lengkap 
dan paling sempurna, komunikasi antarpribadi berperan penting hingga kapanpun, selama manusia masih mempunyai emosi. Kenyataannya komunikasi tatap-muka ini membuat manusia merasa lebih akrab dengan sesamanya, berbeda dengan komunikasi lewat media massa seperti surat kabar, televisi, ataupun lewat teknologi tercanggihpun. Jalaludin Rakhmat (1994) meyakini bahwa komunikasi antarpribadi dipengaruhi oleh persepsi interpersonal; konsep diri; atraksi interpersonal; dan hubungan interpersonal.

\subsection{Persepsi Interpersonal}

Persepsi adalah memberikan makna pada stimuli inderawi, atau menafsirkan informasi inderawi. Persepi interpersonal adalah memberikan makna terhadap stimuli inderawi yang berasal dari seseorang (komunikan), yang berupa pesan verbal dan nonverbal. Kecermatan dalam persepsi interpersonal akan berpengaruh terhadap keberhasilan komunikasi, seorang peserta komunikasi yang salah memberi makna terhadap pesan akan mengakibat kegagalan komunikasi.

\subsubsection{Konsep diri}

Konsep diri adalah pandangan dan perasaan kita tentang diri kita. Konsep diri yang positif, ditandai dengan lima hal, yaitu: a. Yakin akan kemampuan mengatasi masalah; b. Merasa stara dengan orang lain; c. Menerima pujian tanpa rasa malu; d. Menyadari, bahwa setiap orang mempunyai berbagai perasaan, keinginan dan perilaku yang tidak seluruhnya disetujui oleh masyarakat; e. Mampu memperbaiki dirinya karena ia sanggup mengungkapkan aspek-aspek kepribadian yang tidak disenanginya dan berusaha mengubah. Konsep diri merupakan faktor yang sangat menentukan dalam komunikasi antarpribadi, yaitu:

a. Nubuat yang dipenuhi sendiri. Karena setiap orang bertingkah laku sedapat mungkin sesuai dengan konsep dirinya. Bila seseorang mahasiswa menganggap dirinya sebagai orang yang rajin, ia akan berusaha menghadiri kuliah secara teratur, membuat catatan yang baik, mempelajari materi kuliah dengan sungguhsungguh, sehingga memperoleh nilai akademis yang baik.

b. Membuka diri. Pengetahuan tentang diri kita akan meningkatkan komunikasi, dan pada saat yang sama, berkomunikasi dengan orang lain meningkatkan pengetahuan tentang diri kita. Dengan membuka diri, konsep diri menjadi dekat pada kenyataan. Bila konsep diri sesuai dengan pengalaman kita, kita akan lebih terbuka untuk menerima pengalaman-pengalaman dan gagasan baru. 
c. Percaya diri. Ketakutan untuk melakukan komunikasi dikenal sebagai communication apprehension. Orang yang aprehensif dalam komunikasi disebabkan oleh kurangnya rasa percaya diri. Untuk menumbuhkan percaya diri, menumbuhkan konsep diri yang sehat menjadi perlu.

d. Selektivitas. Konsep diri mempengaruhi perilaku komunikasi kita karena konsep diri mempengaruhi kepada pesan apa kita bersedia membuka diri (terpaan selektif), bagaimana kita mempersepsi pesan (persepsi selektif), dan apa yang kita ingat (ingatan selektif). Selain itu konsep diri juga berpengaruh dalam penyandian pesan (penyandian selektif).

\subsection{Atraksi interpersonal}

Atraksi interpersonal adalah kesukaan pada orang lain, sikap positif dan daya tarik seseorang. Komunkasi antarpribadi dipengaruhi atraksi interpersonal dalam hal:

a. Penafsiran pesan dan penilaian. Pendapat dan penilaian kita terhadap orang lain tidak semata-mata berdasarkan pertimbangan rasional, kita juga makhluk emosional. Karena itu, ketika kita menyenangi seseorang, kita juga cenderung melihat segala hal yang berkaitan dengan dia secara positif. Sebaliknya, jika membencinya, kita cenderung melihat karakteristiknya secara negatif.

b. Efektivitas komunikasi. Komunikasi antarpribadi dinyatakan efektif bila pertemuan komunikasi merupakan hal yang menyenangkan bagi komunikan. Bila kita berkumpul dalam satu kelompok yang memiliki kesamaan dengan kita, kita akan gembira dan terbuka. Bila berkumpul dengan denganorang-orang yang kita benci akan membuat kita tegang, resah, dan tidak enak. Kita akan menutup diri dan menghindari komunikasi.

\subsection{Komunikasi Kelompok}

Komunikasi kelompok adalah komunikasi yang berlangsung antara beberapa orang dalam suatu kelompok kecil seperti pada rapat, pertemuan, konferensi. (Arifin, 1984).

\section{Alvin A. Godberg}

Komunikasi kelompok adalah suatu bidang studi penelitian dan terapan yang berfokus bukan pada proses kelompok pada umumnya melainkan pada tingkah laku komunikasi individu-individu di dalam kelompok diskusi kecil yang bersifat tatap muka. 


\section{Michael Burgoon}

Komunikasi kelompok adalah interaksi tatap muka dari tiga individu atau lebih dengan tujuan yang sudah diketahui sebelumnya seperti berbagai informasi pemeliharaan diri, pemecahan masalah yang anggota-anggotanya dapat mengingat karakteristik pribadi anggota kelompok lainnya dengan tepat.

Kesimpulan dari dua definisi diatas adalah :

- Komunikasi kelompok harus bersifat tatap muka.

- Pesertanya lebih dari 2 orang.

Onong U. Effendy

Membagi komunikasi kelompok menjadi dua :

1. Komunikasi Kelompok Kecil

Jika situasi komunikasi antara komunikator dengan setiap komunikannya dapat terjadi dialog (lebih rasional).

2. Komunikasi Kelompok Besar

Jika situasi komunikasi antara komunikator dengan setiap komunikannya sukar terjadi dialog (lebih emosional).

Komunikasi Diadik

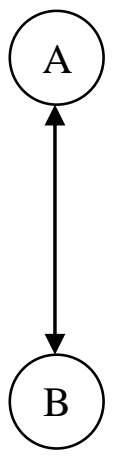

Komunikasi Kelompok

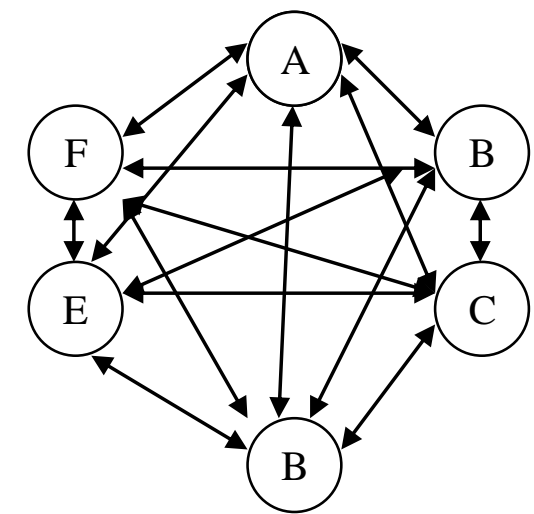

Komunikasi Kelompok yang memusat pada satu orang

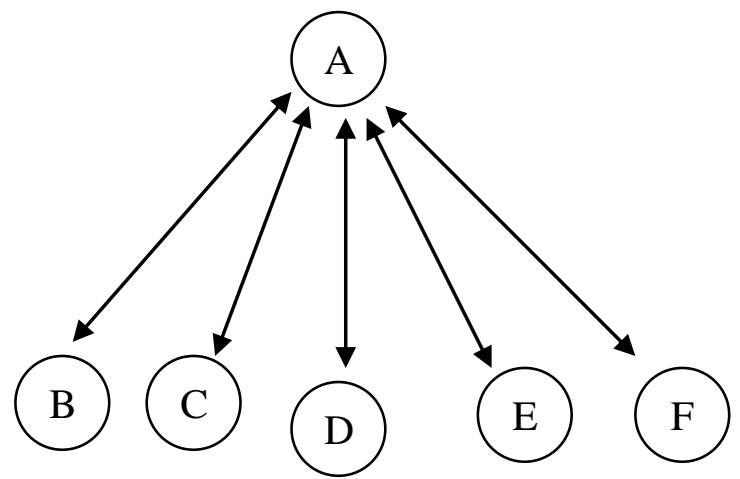

Gambar 7.1: Komunikasi Kelompok Beebe dan Masterson, 1982 
Persamaan Antara Komunikasi Kelompok Dengan Komunikasi Antar Persona

1. Keterlibatan kedua peserta komunikasi secara fisik.

2. Memasyarakatkan komunikasi tatap muka baik secara verbal ataupun nonverbal.

3. Feedback langsung.

Perbedaann Antara Komunikasi kelompok Dengan Komunikasi Antar Persona

1. Komunikan Antar Persona :

a. Keanggotaannya tidak tersusun.

b. Keanggotaannya bersifat sementara dan longgar.

c. Kohesifitas tipis.

d. Tidak mempunyai peran dan tanggung jawab tertentu.

e. Kedudukan komunikator dan komunikan sukar untuk dibedakan secara tegas.

2. Komunikasi Kelompok

a. Keanggotaannya lebih tersusun.

b. Mempunyai anggota yang lebih permanent.

c. Para anggota lebih sadar akan peranan dan tanggung jawabnya.

d. Kedudukan kemunikator relative tetap sebagai komunikan.

e. Kohesivitas tinggi.

\subsection{KARAKTERISTIK KOMUNIKASI KELOMPOK}

1. Kepribadian Kelompok

Tiap individu dalam kelompok mempunyai kepribadian yang berbeda-beda. Pribadi seseorang disaat sendirian dan jika ia berada ditengah kelompoknya biasanya berbeda.

2. Norma Kelompok

Mengidentifikasi cara-cara anggota kelompok itu bertingkah laku serta cara-cara yang menurut pertimbangan kelompok adalah baik.

3. Kohesivitas Kelompok

Kekuatan saling tarik-menarik antara anggotanya atau kekuatan yang menahan mereka agar tetap tinggal dalam suatu kelompok. Kohesivitas kelompok ditentukan olah dua hal :

a. Tingkah laku normative yang cenderung kuat ketika anggota tertarik dan diidentifikasi dengan kelompok.

b. Lamanya menjadi anggota suatu kelompok. Makin lama menjadi anggota suatu kelompok makin terikat dengan kelompok. 
Suatu kelompok dengan kehesivitas yang tinggi ini ditandai dengan:
a. Sifat ramah diantara para anggota.
b. Kooperatif.
c. Mempunyai solidaritas tinggi.

4. Komunikasi kelompok berusaha untuk mencapai tujuan tertentu

a. Setiap Kelompok Seperti:

- Berkeinginan untuk mencapai keberhasilan kelompok

- Berkeinginan untuk menghindari kegagalan kelompok

b. Pergeseran Kelompok

Pergeseran kelompok bisa terjadi pada dampak resiko yang didapat dari resiko individu ke resiko kelompok.

\subsection{JARINGAN KOMUNIKASI}

\section{Daniel C. Fieldman dan Hugh J. Arnold}

Mengatakan ada dua pola jaringan komunikasi dalam organisasi.

a. Jaringan komunikasi formal, terjadi melalui saluran-saluran yang telah ditentukan.

b. Jaringan komunikasi informal, terjadi karena komunikasi terjadi di luar saluransaluran yang telah ditentukan.

\section{Stephen P. Robbins}

Dimensi vertikal dan horizontal dalam komunikasi organisasi dapat digabungkan dalam bermacam-macam pola atau dalam apa yang disebut jaringan-jaringan komunikasi.

\section{James A.F. Stoner dan Charles Wankel}

Seorang manajer memiliki pengaruh terhadp bagaimana saluran-saluran komunikasi itu berkembang dalam unit-unit mereka. Organisasi dapat dengan berbagai cara merencanakan susunan atau jaringan komunikasi mereka.

\section{Elmer H. Burack dan Nicholas J. Mathys}

Menurut Burack dan Mathys setiap kelompok dipengaruhi oleh jaringan komunikasi melalui mana fungsi-fungsinya dijalankan. Jaringan ini dapat merupakan akibat daripada struktur organisasi formal atau timbul karena perilaku khusus dari anggota-anggota kelompok. Bahwa jaringan yang cocok untuk suatu organisasi atau kelompok sebagian besar tergantung kepada hakikat tugas-tugas yang diselesaikan dan tingkat pada mana pegawai-pegawai terlibat dalam kepuaan dan produktivitas. 
Andrew F. Sikula

Menurutnya,

a. Jaringan komunikasi, komunikasi biasanya ditentukan ciri-cirinya sesuai dengan susunan komponennya.

b. Keterlibatan jaringan komunikasi,

Pengaruh jaringan terhadap kegiatan organisasi
a. efisien,
b. mutu hasil
c. kepuasan pegawai
d. tanggapan terhadap perubahan
e. gaya pengawasan
f. pengorganisasi

\section{Referensi}

Berger, Roloff, Ewoldsen, Handbook Ilmu Komunikasi. Terjemah, Nusa Media 2014

Hardjana AM. Komunikasi Intrapersonal dan Interpersonal. Kanisius Yogyakarta. 2003 Hardjana.A. Komunikasi Organisasi. PT.RAJAGRAFINDO PERSADA. 2019

Suranto. Komunikasi Interpersonal. Graha Ilmu. Yogyakarta. 2011

Mulyana.D. Ilmu Komunikasi Suatu Pengantar. PT REMAJA ROSDAKARYA. Bandung. 2007

Onong Uchjana.E. Ilmu Komunikasi Teori dan Praktek. Remaja Karya. Bandung 1995

REED H.BLAKE AND EDWIN O. HAROLDSEN, A.Taxonomy of concepts in Communication, HASTING HOUSE.PUBLISHERS. 1979

Onong Uchjana.E. Dinamika Komunikasi.Remaja Karya CV. Bandung. 1986

Vardiansyah. Pengantar Ilmu Komunikasi. Ghalia Indonesia. 2004

Stephen W. Littlejohn, Theories of Human Communiation, Wadsworth Publication, New Jersey, 1996.

Rakhmat, Jalaluddin. 2009. Psikologi Komunikasi Edisi Revisi. Bandung: Remaja

Rosdakarya 


\section{BAB IX}

\section{Komunikasi Massa}

\section{TUJUAN INSTRUKSIONAL UMUM}

Setelah menyelesaikan materi Bab 9 ini mahasiswa diharapkan mampu:

1. Memahami tentang komunikasi massa

2. Memahami karakteristik komunikasi massa

\section{TUJUAN INSTRUKSIONAL KHUSUS}

Setelah mempelajari materi Bab 9 ini mahasiswa diharapkan mampu:

1. Menjelaskan tentang komunikasi massa

2. Mendiskusikan tujuan dan fungsi tentang komunikasi massa dalam kehidupan seharihari

\subsection{DIFINISI KOMUNIKASI MASSA}

Komunikasi massa adalah komunikasi yang menggunakan media, baik elektronik maupum media cetak sebagai saluran/chanel dalam menyampaikan pesan komunikasi kepada khalayak. Beberapa pakar mempunyai definisi berbeda namun secara konseptual sama maknanya, seperti definisi yang disampaikan oleh :

Bittner

Dalam bukunya Mas Communication: An Itroduction Mass Communication is message communicated through a mass medium to a large number of people.

Gerbner

Komunikasi Massa adalah produksi dan distribusi yang berlandaskan tekhnologian lembaga dari arus pesan yang continue serta paling dimiliki orang dalam masyarakt industri. 


\section{Maletzke}

Komunikasi Massa diartikan setiap bentuk komunikasi yang menyatakan pernyataan secara terbuka melalui media penyebaran tehnis secara tidak langsung dan satu arah pada public yang tersebar.

\section{Freidson}

Komunikasi Massa dialamatkan pada sejumlah populasi dati berbagai kelompok dan bukan hanya satu atau beberapa individu atau sebagian khusus populasi. Komunikasi juga mempunyai anggapan tersirai akan adanya alat-alat khusus untuk menyampaikan komunikasi agar komunikasi itu dapat mencapai pada saat yang sama semua orang yang mewakili berbagai lapisan masyarakat.

\section{Charles R. Wright 1959 Ataxonomy of Concept in Communication}

Komunikasi massa mempunyai karakteristik utama sebagai berikut:

a. Diarahkan pada khalayak yang relative besar.

b. Heterogen dan anonym.

b. Pesan disampaikan secara terbuka.

c. Seringkali dapat mencapai kebanyakan khalayak secara serentak.

d. Bersifat sekilas.

e. Komunikator cenderung bergerak dalam organisasi yang kompleks yang mellibatkan biaya besar.

\section{Alexis S. Tan (1983. 73)}

Dalam komunikasi massa yang penting adalah The communicator is a social organization capable of reproducing the message and sending it, simulated to large number of people who are separated.

\section{Joseph R. Dominick}

Komunikasi massa adalah suatu proses dimana suatu organisasi yang kompleks dengan bantuan satu atau lebih mesin memproduksi dan mengirimkan pesan kepada khalayak yang besar, heterogen, dan tersebar.

\section{Jalaluddin Rakhmat merangkum}

Komunikasi massa adalah jenis komunikasi yang ditujukan kepada sejumlah khalayak yang tersebar, heterogen dan anonim melalui media cetak atau elektronik sehingga pesan yang sama dapat diterima secara serentak dan sesaat. 


\section{Littlejohn}

Komunikasi Massa adalah suatu proses dengan mana organisasi media memproduksi dan mentransmisikan pesan kepada publik yang besar dan proses dimana pesan itu dicari, digunakan, digunakan, dimengerti dan dipengaruhi oleh audience.

\section{De Fleur \& McQuails}

Komunikasi massa sebagai suatu proses melalui mana komunikator menggunakan media untuk menyebarluaskan pesan secara luas \& terus menerus menciptakan makna serta diharapkan mempengaruhi khalayak besar dan beragam.

Kesimpulan dari semua difinisi yang disampaikan para pakar diatas adalah sebagai berikut:

1. Satu arah sehingga unpan baliknya adalah deleyed feedback.

2. Pesannya bersifat umum.

3. Media komunikasi massa menimbulkan keserempakan.

4. Komunikan komunikasi massa bersifat heterogen.

5. Hubungan antara peserta komunikasi bersifat impersonal atau non pribadi karena kemunikan anonim.

6. Tidak ada interaksi antara komunikator dan komunikan secara fisik.

7. Komunikatornya melembaga (collective communication)

8. Cepat, Dalam komunikasi massa proses penyampaian pesan bisa lebih cepat karena kecanggihan teknologi, misal: adanya teknologi detak dari jarak yang jauh.

9. Berkelanjutan, Dalam penyampaian pesan komunikasi massa tidak sepotong sepotong, melainkan terus berkelanjutan misal: Kasus yang sedang hangat diberitakan di TV mengenai operasi wajah yang disiarkan secara terus menerus.Pesan media massa bersifat umum (tidak ditujukan untuk pribadi tetapi untuk khalayak luas, heterogen)

10. Kesamaan makna, Pesan yang disampaikan bertujuan untuk meciptakan kesamaan makna diantara khalayak. Kesamaan makna muncul karena keserampakan/serentak pada waktu yang sama. Pada kenyataannya meskipun pesan yang disampaikan sama tetapi makna yang dimunculkan berbeda-beda pada setiap khalayak

11. Mempengaruhi khalayak, Komunikasi massa bertujuan untuk membentuk satu sikap \& perilaku tertentu. Komunikasi massa dapat membentuk opini publik 
yang dapat mempengaruhi sikap dan perilaku khalayak sesuai dengan tujuan yang ingin dicapai komunikator.

12. Feedback tertunda, Dahulu feedback mungkin tertunda tetapi untuk sekarang ini sudah tidak relevan lagi karena sekarang banyak acara yang bersifat interaktif, sehingga komunikan bisa langsung memeberikan tanggapan atau feedback Berikut penjelasan karakteristik komunikasi massa yang telah disimpulkan di atas:

Pesan dalam komunikasi massa bersifat umum dalam artian disampaikan kepada umum dan yang menyangkut kepentingan umum. Pesan tersebut diproses, distandarisasi dan diperbanyak.

Pesan merupakan suatu produk dan komoditi yang mempunyai nilai tukar serta acuan simbolik yang punya nilai kegunaan.

Pesan yang disampaikan lewat media massa biasanya sudah bias diperkirakan sehubungan dengan peristiwa-peristiwa yang sedang terjadi.

Pesan-pesan yang tidak bersifat umum dan tidan menyangkut kepentingan umum tapi ditampilkan lewat media massa karena pesan terseut mempunyai nilai berita atau menyangkut seorang tokoh (human interest).

Dengan demikian maka pesan yang akan disampaikan dalam media massa harus direncanakan dengan matang dan harus diperhitungkan khalayak sasaran (target audience - umum) dan khalayak kelompok (target group - khusus).

Komunikan, Komunikan dalam komunikasi massa bersifat heterogen, anonym dan tersebar luas. Heterogen, maksudnya beragan dari berbagai usia, jenis kelamin, pekerjaan, pendidikan dan pendapatan. Anonim, maksudnya antara komunikator dan komunikan tidak mutlak harus saling kenal, demikian juga dengan sesame komunikan. Jadi komunikator tidak bias memperhitungkan pesan-pesan yang disampaikan akan diterima oleh siapa saja karena komunikator tidak mengenal komunikan dan sebaliknya. Tersebar luas, maksudnya komunikan dalam komunikasi massa tidak berkumpul jadi satu audience tapi berpencar-pencar.

Menibulkan keserempakan, artinya pesan komunikasi massa dapat diterima secara bersamaan ditempat yang berbeda dalam waktu yang sama.

Tidak ada interaksi fisik, artinya antara komunikator dan komunikan tidak ada interaksi fisik secara langsung karena komunikasi massa prosesnya menggunakan salauran media baik elektronik maupun cetak. 


\subsection{Penyebaran Arus Anonym Komunikasi Massa Ada 4 Model}

\subsubsection{Model Jarum Hipodermik/Jarum Suntik/Peluru}

Pesan dari komuikator langsung disampaikan kepada komunikan. Dalam hal ini media massa sangat berpengaruh dalam merubah perilaku audience tanpa halangan apapun, dengan Model S - M - C - R - E, Sifat khalayak pasif/tidak penting, efek sama sebab atomistic (tergantung pada media)

\subsubsection{Model Komunikasi Satu Tahap}

Audience langsung mendapatkan informasi dari media massa. Beberapa perbedaan antara model komunikasi satu tahap dengan model jarum hipodermik.

\begin{tabular}{|c|c|}
\hline Model komunikasi Satu Tahap & Model Jarum Hipodermik \\
\hline $\begin{array}{l}\text { 1. Media massa dianggap tidak } \\
\text { mungkin mempunyai kekeuatan yang } \\
\text { sama dalam mempengaruhi audience. } \\
\text { 2. Selektifitas menentukan penerimaan } \\
\text { audience. } \\
\text { 3. Mengakui timbulnya reaksi yang } \\
\text { berbeda terhadap pesan yang sama. } \\
\text { 4. Mengakui keeksistensian individu } \\
\text { (audience masih diperbolehkan } \\
\text { memilih pesan) }\end{array}$ & $\begin{array}{l}\text { 1. Kekuatan semua media massa } \\
\text { dianggap sama. } \\
\text { 2. Tidak memberi kesempatan pada } \\
\text { audience untuk memilih. } \\
\text { 3. Tidak mengakui (reaksi harus sama } \\
\text { seperti yang dikehendaki). } \\
\text { 4. Tidak mengakui }\end{array}$ \\
\hline
\end{tabular}

\section{Model Satu Tahap}

Media massa

Komunikator

\subsubsection{Model Komunikasi Dua Tahap}

Media massa tidak begitu besar pengaruhnya dalam mempengaruhi audience. Kesimpulannya, ternyata arus penyebaran informasi kepada komunikan melalui dua tahap.

Asumsi Dasar

Media massa tidak perkasa

Audiece tidak atomistic karena masih berhubungan dengan pemuka pendapat dan kelompoknya. 
Kelompok Model Komunikasi Dua Tahap

Pemuka pendapat tidak selalu aktif mencari informasi.

Arus penyebaran informasi tidak selalu dua tahap tapi bias juga satu tahap atau multi tahap.

Pemuka pendapat tidak hanya mendapatkan informasi dari media massa tapi juga dari penyuluh pembangunan.

Model komunikasi dua tahap tidak menunjukkan adanya perbedaan peranan dari berbagai saluran komunikasi.

Tidak selalu nereka yang bukan pemimpin dianggap pengikut pemuka pendapat, sehingga pemisahan antara audience dan pemuka pendapat dalam masyarakat pengikut tidak selalu benar.

Kriteria seorang pemuka pendapat

Lebih tinggi status sosial dan pendidikannya serta tingkat ekonominya.

Lebih inovatif dalam mengadopsi ide baru.

Lebih tinggi pengalaman medianya.

Kemampuan empatinya lebih besar dan lebih kosmopolit.

\subsubsection{Model Komunikasi Multi Tahap}

Audience menerima informai dari berbagai sumber dan lelaui banyak tahap. Informasi tidak hanya langsung bias di dapat dari media massa, tapi juga dari mulut ke mulut. Dengan kata lain adanya variasi penyebaran informasi dari sumber kepada audience.

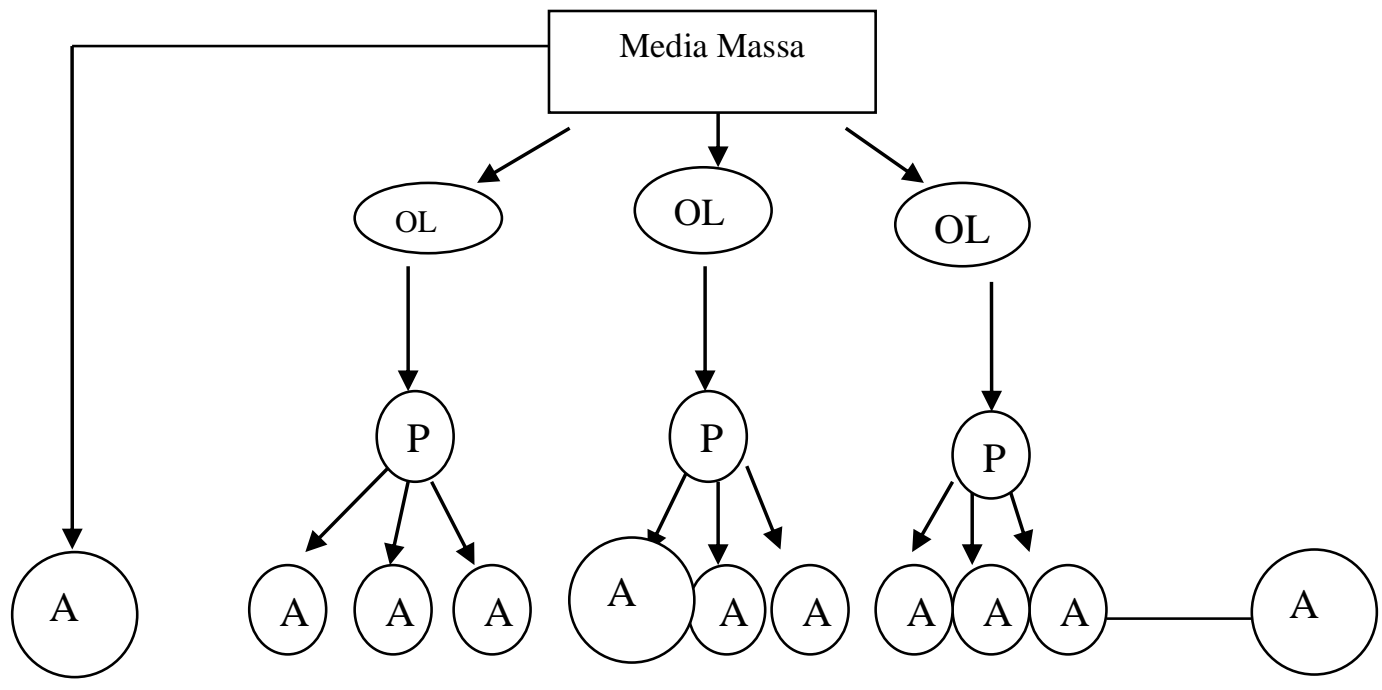

Gambar 9.1: Model Komunikasi Multi Tahap 
Keterengan:

Proses Komunikasi dari Media Massa

OL : Opinion Leader (pemuka pendapat)

P : Partisipan

A : Audience

Hal-hal pokok yang perlu diperhatikan dalam model multi tahap:

Apa tujuan dari sumber informasi.

> Banyaknya mass media yang menyebarkan informasi.

$>$ Isi pesan yang disampaikan harus menarik perhatian audience dan melibatkan kepentingan mereka.

cara penyampaian juga harus menarik perhatian audience.

Beberapa perbedaan antara aluran Komunikasi Antarpribadi dan Saluran Media Massa.

\begin{tabular}{|l|l|l|}
\hline \multicolumn{1}{|c|}{ Karakteristik } & \multicolumn{1}{|c|}{$\begin{array}{c}\text { Saluran Komunikasi } \\
\text { Antarpribadi }\end{array}$} & \multicolumn{1}{|c|}{$\begin{array}{c}\text { Saluran Komunikasi } \\
\text { Media Massa }\end{array}$} \\
\hline 1. Sifat & Dua arah & Satu arah \\
2. Konteks Komunikasi & Tatap muka & Bermedia \\
3. Tingkat Umpan balik & Tinggi & Rendah \\
$\begin{array}{l}\text { 4. Kemampuan mengatasi } \\
\text { tingkat selek-tifitas. }\end{array}$ & Tinggi & Rendah \\
$\begin{array}{l}\text { 5. Kecepatan jangkauan } \\
\text { terhadap audience } \\
\begin{array}{l}\text { 6. Efek yang mungkin } \\
\text { terjadi }\end{array}\end{array}$ & Lambat & Relatif cepat \\
\end{tabular}

\subsection{Perbedaan Komunikasi Massa \& Tatap Muka}

Perbedaan secara teknis menurut Elizabeth Noelle-Neuman ada 4 tanda pokok dari komunikasi massa yang tidak terdapat pada komunikasi interpersonal:

$>$ Bersifat tidak langsung

Bersifat searah

Bersifat terbuka

$>$ Mempunyai publik yang tersebar secara geografis

\subsection{Proses \& Model Kommunikasi Massa}

\subsubsection{Komunikasi Primer}

Proses komunikasi yang tidak menggunakan media tetapi menggunakan lambang/simbol sebagai media satu-satunya, ada 2 jenis lambang: 
Verbal, lambang/simbol/pesan yang berupa kata-kata (lisan/tulisan)

Non Verbal, Bahasa tubuh/body language/ekspresi wajah dan kontak mata Paralinguistik

Dialek: cara orang berbicara

Intonasi

Volume suara

Kecepatan berbicara

\subsubsection{Komunikasi Sekunder}

Proses penyampaian \& penerimaan pesan dengan menggunakan media sebagai sarana komunikasi, berikut ciri komunikasi interpersonal

Media massa

Media non massa (interpost media)

\subsubsection{Proses Komunikasi Massa}

Secara menyeluruh (holistic) dapat dipandang dari 3 cara:

Dari sudut pandang media

Dari sudut pandang komunikator

Dari sudut pandang khalayak

\section{Ciri media:}

$>$ keuntungan/profit

$>$ kapitalisme

$>$ kompetensi

\subsection{HAMBATAN DALAM KOMUNIKASI MASSA}

\section{> Hambatan Psikologi}

Seperti kepentingan, prasangka, stereotipe dan motivasi

$>$ Hambatan Sosiokultural
a. Aneka etnik
b. Perbedaan norma sosial
c. Kurang mampu berbahasa Indonesia
d. Faktor semantik
e. Pendidikan belum merata
f. Hambatan mekanis 


\section{> Hambatan Interaksi Verbal}
a. Polarisasi
b. Orientasi intensional
c. Evaluasi statis
d. Indiskriminasi

\subsection{FUNGSI KOMUNIKASI MASSA BAGI MASYARAKAT}

\section{Menurut Dominick :}

1. Surveillance (pengawasan)

Warning before surveillance (pengawasan peringatan), fungsi yang terjadi ketika Media Massa menginformasikan tentang ssuatu yang berupa ancaman, ex. Bahaya tsunami, banjir, gempa, kenaikan harga, dll.

$>$ Instrumental surveillance (pengawasan instrumental), penyebaran/penyampaian informasi yang memiliki kegunaan atau dapat membantu khalayak dalam kehidupan sehari-hari ex. Resep masakan, produk-produk baru, dll.

2. Interpretation (penafsiran)

Media Massa tidak hanya memasok fakta dan data, tetapi juga meberikan penafsiran terhadap kejadian-kejadian penting, ex. Tajuk rencana (editorial) berisi komentar dan opini dilengkapi perspektif terhadap berita yang disajikan di halaman lain.

3. Linfkage (pertalian)

Media massa dpat menyatukan anggota masyarakat yang beragam, sehingga membentuk lingkage (pertalian) berdasarkan kepentingan dan minat yang sama tentang sesuatu, ex. SBY undur diri dari kabinet Megawati dan menaikkan pamor Partai Demokrat.

4. Transmission of values (penyebaran nilai-nilai)

Fungsi sosialisasi: cara dimana individu mengadopsi perilaku dan nilai kelompok.

5. Entertainment (hiburan)

Banyak kita jumpai pada media televisi dan radio

Secara singkat dapat diartikan bahwa komunikasi massa adaah proses komunikasi yang menggunakan media massa. Media massa dibagi menjadi dua yaitu media cetak dan media elektronik. Sasaran dari komunikasi massa adalah khalayak yang luas, beragam dan tidak ditujukan pada satu golongan tertentu. Sasaran yang begitu luas 
terkadang tidak menjadikan feedback langsung terjadi, terkecuali pada komunikasi massa yang bersifat langsung atau atau interaktif.

Dalam komunikasi massa tetap terjadi hambatan - hambatan yang sama seperti proses komunikasi pada umumnya. Komunikasi massa menurut De Vito (1996) adalah milik umum, setiap orang dapat mengetahui pesan-pesan komunikasi melalui media massa, karena komunikasi berjalan cepat maka pesan yang akan disampaikan kepada khalayak silih berganti tanpa selisih waktu.

Sifat penyebaran pesan yang berlansung cepat dan serempak serta luas mampu mengatasi jarak dan waktu. Dapat bertahan lama bila didokumentasikan. Dari segi ekonomi biaya untuk memproduksi komunikasi massa cukup mahal dan memerlukan dukungan tenaga kerja yang relatif banyak untuk mengelolanya

\section{Referensi}

McQuail's. Mass Communication Theory.Salemba Humanika. 2011

Elvinaro dan Lukiati. Komunikasi Massa Suatu Pengantar. Sembiosa Rekatama Media. 2004

Rakhmat, Jalaluddin. 2009. Psikologi Komunikasi Edisi Revisi. Bandung: Remaja Rosdakarya

Mulyana, Deddy. Ilmu Komunikasi Suatu pengantar, PT Remaja Rosdakarya Offset. Bandung, 1997.

Cangara, Hafied. Pengantar Ilmu Komunikasi, PT Raja Grafindo Persada. Jakarta. 2004

Devito, Joseph A. Komunikasi Antar Manusia edisi ke-5, Professional Books. 1997

Sasa Djuarsa S., Teori Komunikasi, Universitas Terbuka, Jakarta. 2003

John Fiske, Introduction to Communication Studies, Sage Publications, 1996

Stephen W. Littlejohn, Theories of Human Communiation, Wadsworth Publication, New Jersey, 1996.

Brent D. Ruben, Communication and Human Behaviour, Prentice Hall, New Jersey, 2004

Effendi, Onong Uchjana. 1993. Ilmu, Teori \& Filsafat Komunikasi. Bandung: Citra Aditya Bakti.

Blake, R.H, dan Haroldsen, E.O. 2005. Taksonomi Konsep Komunikasi. Surabaya: Papyrus.

Berger, Roloff, Ewoldsen, Handbook Ilmu Komunikasi. Terjemah, Nusa Media 2014

Vardiansyah. Pengantar Ilmu Komunikasi. Ghalia Indonesia. 2004

John Fiske. Pengantar Ilmu Komunikasi. PT. Raja Grafindo Persada 2012

Rakhmat, Jalaluddin. 2009. Psikologi Komunikasi Edisi Revisi. Bandung: Remaja

http://nurriest.blogdrive.com/archive/5.html

aurajogja.files.wordpress.com/2006/09/komunikasi-massa-a5.PDF

http://inherent.brawijaya.ac.id/vlm/login/index.php

http://blog.persimpangan.com/blog/2007/08/04/komunikasi-massa/ 


\section{BAB X \\ Model-Model Komunikasi}

\section{TUJUAN INSTRUKSIONAL UMUM}

Setelah menyelesaikan materi Bab 10 ini mahasiswa diharapkan mampu:

1. Memahami tentang model-model komunikasi

2. Memahami fungsi model komunikasi

\section{TUJUAN INSTRUKSIONAL KHUSUS}

Setelah mempelajari materi Bab 10 ini mahasiswa diharapkan mampu:

1. Menjelaskan tentang model-model komunikasi

2. Mendiskusikan tujuan dan fungsi model komunikasi

\subsection{PENGERTIAN MODEL}

Suatu fenomena komunikasi seringkali merupakan hal yang abstrak. Model merupakan representasi suatu fenomena, tapi model bukanlah fenomena. Model merupakan suatu bentuk gambaran untuk mempermudah kita memahami fenomena. Suatu model merepresentasikan secara abstrak ciri-ciri penting dan menghilangkan rincian komunikasi yang tidak perlu dalam dunia nyata. Model adalah gambaran analogi yang mengabstraksikan dan memilih bagian dari keseluruhan. Terlepas dari baik dan buruknya model komunikasi yang kita kembangkan, waktu dan keadaan juga menjadi faktor yang layak menjadi pertimbangan untuk mengimplementasikan model komunikasi tersebut.

Berikut adalah pengertian model komunikasi dari beberapa pakar:

1. Sereno \& Mortensen: suatu model komunikasi merupakan deskripsi ideal mengenai apa yang dibutuhkan untuk terjadinya komunikasi.

2. Aubrey Fisher: model adalah analogi yang mengabtraksikan dan mmeilih bagian dari keseluruhan, unsur, sifat atau komponen yang penting dari fenomena yang dijadikan model-model adalah gambaran informal untuk menjelaskan atau menerapkan suatu teori. 
3. Severin \& Tankard: model membantu merumuskan suatu teori dan menyarankan hubungan.Lazimnya unsur perancang model terdiri dari serangkai blok, segi empat, lingkaran, panah, garis, spiral dsb serta dilengkapi dengan huruf, kata2 dan angka.

\subsection{FUNGSI DAN MANFAAT MODEL KOMUNIKASI}

Menurut Wiseman \& Barker : tiga fungsi model yaitu;

a. Melukiskan proses komunikasi.

b. Menunjukkan hubungan visual

c. Membantu dlm menemukan dan memperbaiki kemacetan komunikasi

Menurut Deutsch (1966) ada empat fungsi model itu, yaitu:

a. Organizing function, mengorganisasikan (kemiripan data dan hubungan) yang tadinya tidak teramati. Suatu model memberi gambaran umum suatu keadaan tertentu yang berbeda.

b. Explaining, menunjukkan fakta-fakta dan metode baru yang tdk diketahui (heuristik)

c. To predict, sebuah model memungkinkan kita untuk memprediksi outcome atau keadaan dari suatu peristiwa.

d. Mengukur fenomena (pengukuran)

Ada beberapa hal yang perlu dipertimbangkan dalam menilai suatu model komunikasi:

a. Seberapa umum (general) model tersebut ?

b. Seberapa banyak bahan yang diorganisasikan dan seberapa efektif ?

c. Seberapa heuristik model tersebut ? (apakah membantu menemukan hubunganhubungan baru, fakta atau metode)

d. Seberapa penting prediksi yang dibuat model tersebut bagi penelitian ?

e. Seberapa akurat pengukuran yang dapat dikembangkan dgn model tersebut?

f. Seberapa strategis prediksi itu pd tahap perkembangan bidang tersebut ?

Dalam menilai model, Deutsch menambahkan beberapa hal berikut: pertama, Orisinalitas model, kedua, seberapa banyak pandangan baru yang ditawarkan ?ketiga, Bagaimana kesedehanaan dan kehematan model tersebut ? keempat, seberapa nyata model tersebut kelima, keenam, seberapa jauh kita bergantung pada model tersebut sebagai representasi realitas fisik ?

Berikut beberapa model komunikasi : 


\subsection{MODEL H LASWELL}

Harold Laswell seorang ilmuwan dalam bidang ilmu politik dari Yale University dalam artikelnya tahun 1948 menyebutkan sebuah model komunikasi yang mungkin paling dikenal sepanjang masa. Model ini muncul dalam perkembangan studi Laswell tantang propaganda politik. Model ini merupakan sebuah pandangan umum tentang komunikasi yang dikembangkan dari batasan ilmu politik. Menurut Lasswel, persoanal komunikasi menyangkut 5 (lima) pertanyaan sederhana sebagai berikut :

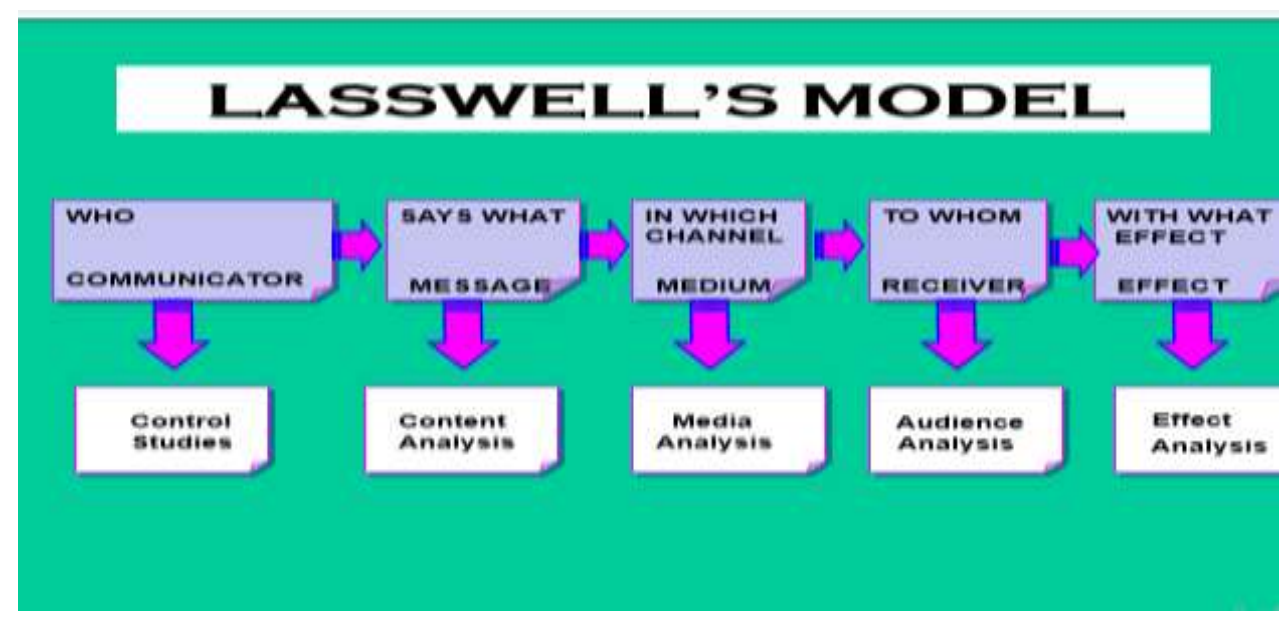

Gambar 10.1: Model KomunikasiLasswell

$>$ Who? (siapa)

$>$ Says What? (mengatakan apa)

$>$ In Which Channel? (melalui saluran apa)

$>$ To Whom? (kepada siapa)

$>$ With What Effect? (dengan akibat apa)

Bila dilihat lebih lanjut maksud dari model lasswell adalah yang pertama menunjukkan kepada siapa orang yang mengambil inisiatif untuk memulai komunikasi. Pertanyaan kedua adalah say what atau yang dikatakan. Pertanyaan ini adalah berhubungan dengan isi komunikasi atau apa pesan yang disampaikan dalam komunikasi tersebut.

Pertanyaan ketiga adalah to whom. Pertanyaan ini maksudnya menanyakan siapa yang menjadi audience atau penerima dari komunikasi. Atau dengan kata lain kepada siapa komunikator berbicara atau kepada siapa pesan yang ia ingin sampaikan diberikan. 
Pertanyaan ketiga adalah through what atau melalui media apa. Yang dimaksudkan dengan media adalah alat komunikasi, seperti berbicara, gerakan dll.Yang perlu diperhatikan dalam hal ini adalah tidak semua media cocok untuk maksud tertentu. Kadang- kadang suatu media lebih efesien digunakan untuk maksud tertentu tetapi untuk maksud yang lain tidak.

Pertanyaan terakhir dari model Lasswell ini adalah what effect atau apa efeknya dari komunikasi tersebut. Pertanyaan mengenai efek komunikasi ini dapat menanyakan dua hal yaitu apa, yang ingin dicapai dengan hasil komunikasi tersebut dan kedua, apa yang dilakukan orang sebagai hasil dari komunikasi, akan tidak hanya disebabkan oleh faktor hasil komunikasi tetapi juga dipenggaruhi oleh faktor lain.

Model Laswell ini konsepnya sama dengan model Aristoteles yaitu sama-sama menekankan pada elemen speaker, message \& audience (tetapi menggunakan istilah yang berbeda), Baik Laswell maupun Aristoteles sama-sama melihat komunikai sebagai proses satu arah dimana inidividu dipengaruhi individu lain sebagai akibat dari pengiriman pesan. (Ruben, 1992:25).

Laswell sendiri menggunakan formulanya untuk menunjukkan jenis penelitian komunikasi (windahl, 1993:14). Penggambaran Laswell tentang berbagi bidang dalam penelitian komunikasi memang berguna tetapi disisi lain penggambaran tersebut terlalu menyederhanakan bidang penelitian komunikasi itu sendiri. Braddock (1958) menambahkan dua hal dalam model Laswell yang dapat mempengaruhi tindakan komunikasi:

1. Dalam situasi dan keadaan bagaimana sebuah pesan itu dikirimkan

2. Untuk tujuan apa komunikator mengirimkan pesan

Menurut Windahl model Laswell ini menggambarkan karakter awal model komunikasi. Sudah dianggap taken for granted bahwa komunikator itu selalu memiliki kesadaran untuk mempengaruhi komunikan, jadikomunikasi dilihat sebagai suatu proses persuasif. Lasswell mengemukakan tiga fungsi komunikasi yaitu:

1. Pengawasan lingkungan,

2. Korelasi berbagai bagian terpisah dlm masyarakat yang merespon lingkungan

3. Transmisi warisan sosial.

Ciri-ciri model komunikasi Laswell:

1. Komunikator memegang kendali dalam proses komunikasi.

2. Komunikator berusaha mempengaruhi komunikan, sehingga komunikasi bersifat persuasive. 
3. Pesan yang disampaikan selalu ada efeknya.

4. Komunikasi bersifat pasif.

Sifat model komunikasi yang dikemukakan oleh Lasswel:

1. Bersifat linear atau satu arah

2. Tidak ada feedback

3. Persuasive

4. Bersifat propaganda

Kritik yang diterima oleh model komunikasi Laswell:

1. Tidak ada feedback

2. Tidak memperhatikan situasi pada saat komunikasi berlangsung

3. Masing-masing unsure komunikasi terpisah, padahal sebenarnya komunikasi berlangsung terus menerus.

4. Bisa menimbulkan salah pengertian karena terlalu sederhana dan kurang lengkap.

\subsection{MODEL SHANNON DAN WEAVER (1949)}

Model ini berbeda dengan model Lasswell mengenai istilah yang digunakan bagi masing-masing komponen seperti dapat dilihat pada gambar di bawah ini. Selain itu Model Matematik atau Model Shannon dan Weaver (1949) melihat komunikasi sebagai proses pemancaran pesan. Claude Shannon and Warren Weaver bukanlah seorang ilmuwan social. Mereka adalah insiyur yang bekerja untuk laboratorium telephone Bell di Amerika Serikat. Tujuan mereka adalah untuk memastikan "the maximum efficiency" dari kabel telephone dan gelombang radio. Mereka mengembangkan sebuah model komunikasi yang ditujukan untuk membantu mengembangkan sebuah teori matematis dari komunikasi (Chandler).

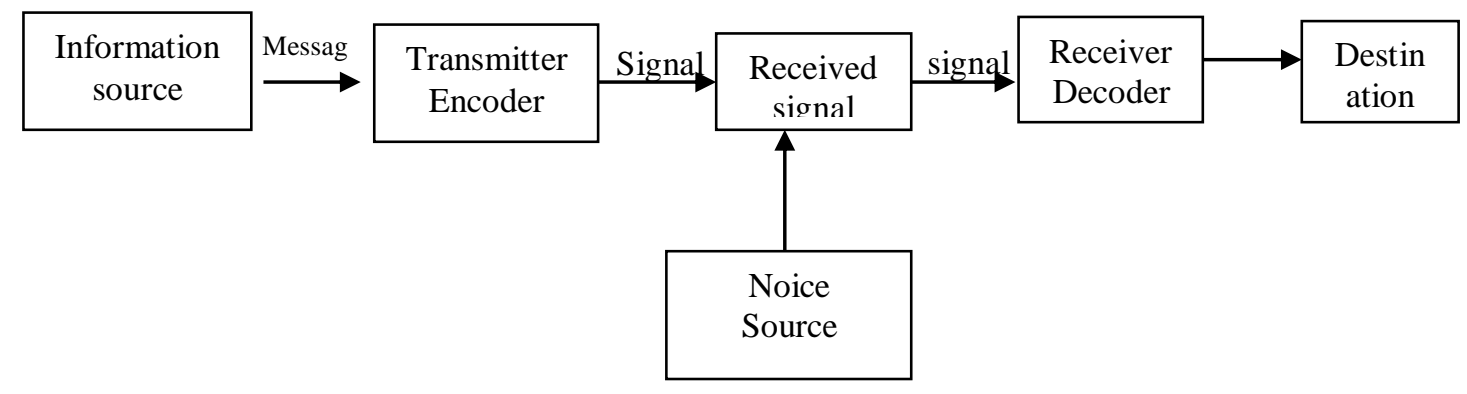

Gambar 10.2 : Model Komunikasi Shannon dan Weaver 


\section{a. Sumbe Informasi ( information source)}

Dalam komunikasi manusia yang menjadi sumber informasi adalah otak.

\section{b. Transmiter}

Langkah kedua dari model Shannon adalah memilih Transmiter. Pemilihan transmitter ini tergantung pada jenis komunikasi yang digunakan. Kita dapat membedakan dua macam komunikasi yaitu komunikasi tatap muka dan komunikasi mengunakan mesin.

\section{c. Penyandian (Econding ) pesan}

Penyandian ( econding ) pesan diperlukan untuk mengubah ide dalam otak ke dalam suatu sandi yang cocok dengan transmiter. Dalam komunikasi tatap muka signal yang cocok dengan alat-alat suara adalah berbicara. Signal yang cocok dengan otot-otot tubuh dan indera adalah aggukan kepala, sentuhan dan kontak mata.

\section{d. Penerimaan dan Econding}

Istilah Shannon mengenai penerima dan deconding atau penginterprestasikan pesan seperti berlawanan dengan istilah penyandian pesan.

\section{e. Tujuan (Destination)}

Komponen terakhir Shannon adalah destination ( tujuan ) yang dimaksud oleh si komunikator. Destination ini adalah otak manusia yang menerima pasan yang berisi barmacam-macam hal, ingatan atau pemikiran mengenai kemungkinan dari arti pesan.

\section{f Sumber Ganguan ( Noise )}

Dalam model komunikasi Shannon initerlihat adanya faktor sumber gangguan pada waktu memindahkan signal dari transmitter kepada si penerima. Gangguan ini selalu ada dalam tiap-tiap komunikasi. Oleh sebab itu kita harus siap menetralkan gangguan dan tidak terkejut dengan kehadirannya. Untuk menetralkan gangguan ini Shannon mengemukan empat cara seperti berikut:

Shannon dan Weaver mengidentifikasi tiga level masalah dalam studi komunikasi:

1. Level A (masalah teknis), bagaimana simbol-simbol komunikasi dapat ditransmisikan secara akurat? awal mula pengembangan model ini.

2. Level B (masalah semantik), bagaimana simbol2 yang ditransmisikan secara persis menyampaikan makna yang diharapkan? 
3. Level C (masalah keefektifan), bagaimana makna yang diterima secara efektif mempengaruhi tingkah laku dengan cara yang diharapkan?

\subsection{MODEL KOMUNIKASI MELVIN DE FLEUR 1966}

Model komunikasi yang dibuat oleh Melvin DeFleur pada dasarnya merupakan pengembangan dari model komunikasi yang dibuat oleh Shannon dan Weaver. Model DeFleur ini cocok untuk menggambarkan proses komunikasi melalui media massa (komunikasi massa). Di dalamnya tercakup delapan komponen proses komunikasi massa, yaitu: Sumber (source), Pemancar (transmitter), Saluran (channel), penerima (receiver), Tujuan (destination), Gangguan (noise), sarana medium massa ( mass medium device), dan sarana penyampai umpan balik (feedback device).

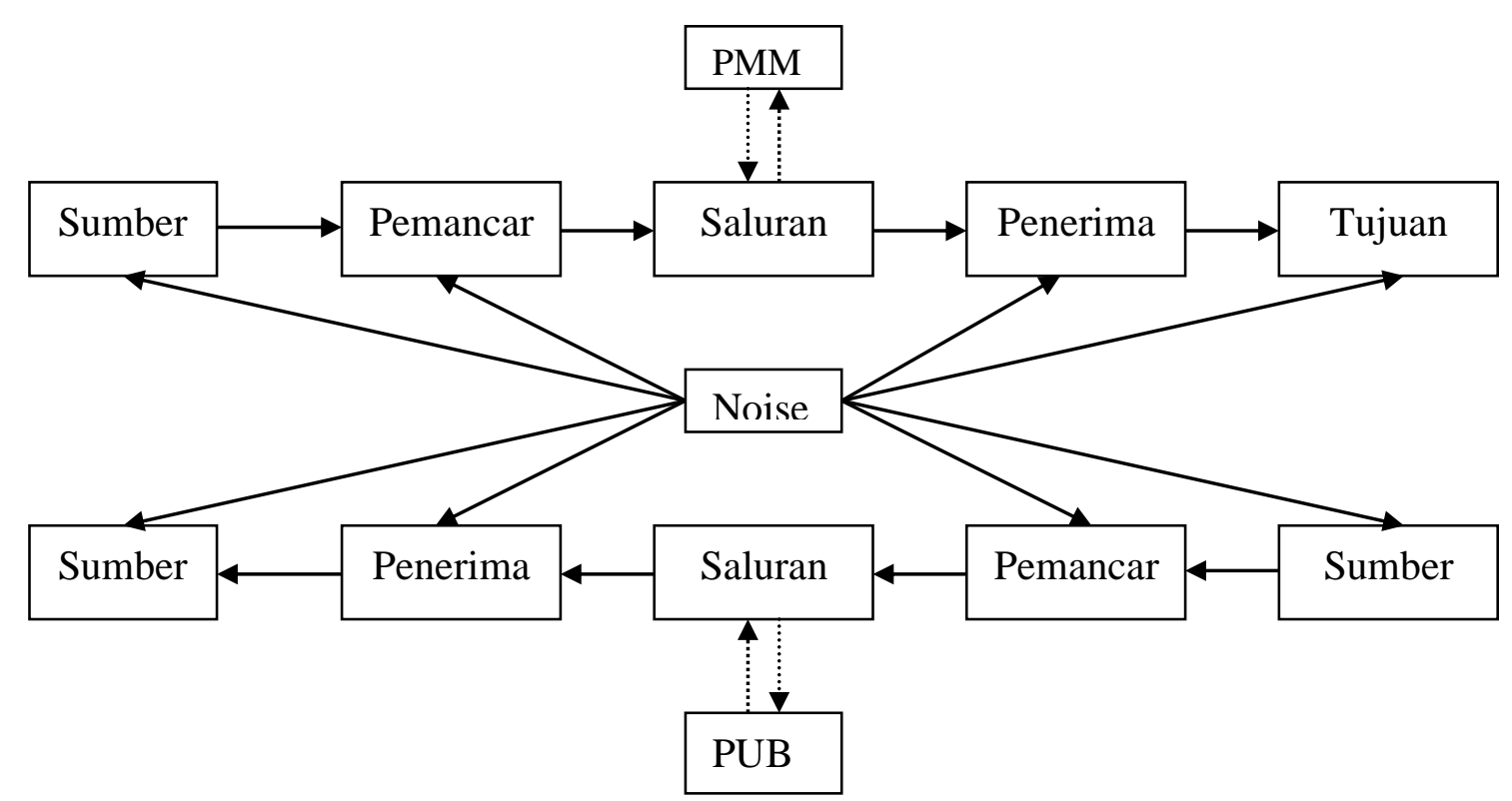

Gambar 10.3: Model Komunikasi Melvin DeFleur

Keterangan :

PMM : Perangkat Media Massa

PUB : Perangkat Umpan Balik

Sumber (source) yang bermaksud mengkomunikasikan sesuatu hal kepada sasaran penerima (destination) pertama-tama akan terlibat dalam proses pengolahan atau pembentukan simbol-simbol pesan melalui transmiter, sehingga menghasilkan suatu pesan yang bermakna. 
Simbol-simbol pesan ini kemudian disampaikan me!alui suatu saluran atau channel (medium komunikasi massa seperti surat kabar, majalah, radio, TV, dan lainlain).

Pihak penerima (receiver) menerima simbol-simbol pesan tersebut melalui alat penerima tententu. Pihak penerima dalam menerima pesan tersebut juga terlibat dalam proses pengolahan dan pengartian makna pesan dan kemudian bertindak menjadi sumber informasi (source) membentuk simbol-simbol pesan tanggapannya melalui transmitter.

Selanjutnya transmitter mengirim kembali pesannya tersebut melalui suatu saluran medium komunikasi massa (channel) kepada pihak sasaran penerima (yakni sumber pertama yang mengirim pesan dan sekarang bertindak sebagai destination). Demikianlah proses ini terus berlangsung secara dinamis dan berjalan secara timbal balik. Namun, dalam prakteknya proses komunikasi yang terjadi tidak bisa luput dan adanya gangguan-gangguan.

Gangguan dapat timbul pada unsur pengirim, transmitter, saluran yang dipergunakan, pihak penerima atau pada pengartian makna pesan. Namun, menurut DeFleur, adanya gangguan inilah yang menyebabkan proses komunikasi yang terjadi berjalan lebih dinamis. (Djuarsa Sendjaja)

\subsection{MODEL BERLO (1960)}

Model komunikasi Berlo dikenal dengan model SMCR (source, message, chanel, receiver), model ini menekankan pada efektivitas komunikasi, proses komunikasi serta menekankan juga pada ide bahwa meaning are in the people atau arti pesan yang dikirim pada orang yang menerima pesan bukan pada kata-kaat pesan itu sendiri. Dengan kata lain dapat dikatakan bahawa interprestasi pesan terutama tergantung kepada arti dari kata atau pesan yang ditafsirkan oleh si pengirim atau si penerima pesan dan bukan pada apa yanga ada dalm komponen pasan itu sendiri.

Model ini hanya memperlihatkan proses komunikasi satu arah dan dalam prosesnya hanya terdiri dari empat komponen yaitu sumber pesan, saluran dan penerima atau receiver Berlo (1960), kesemua elemen ini penting dalam menyampaikan pesan dalam memastikan jalannya komunikasi. 


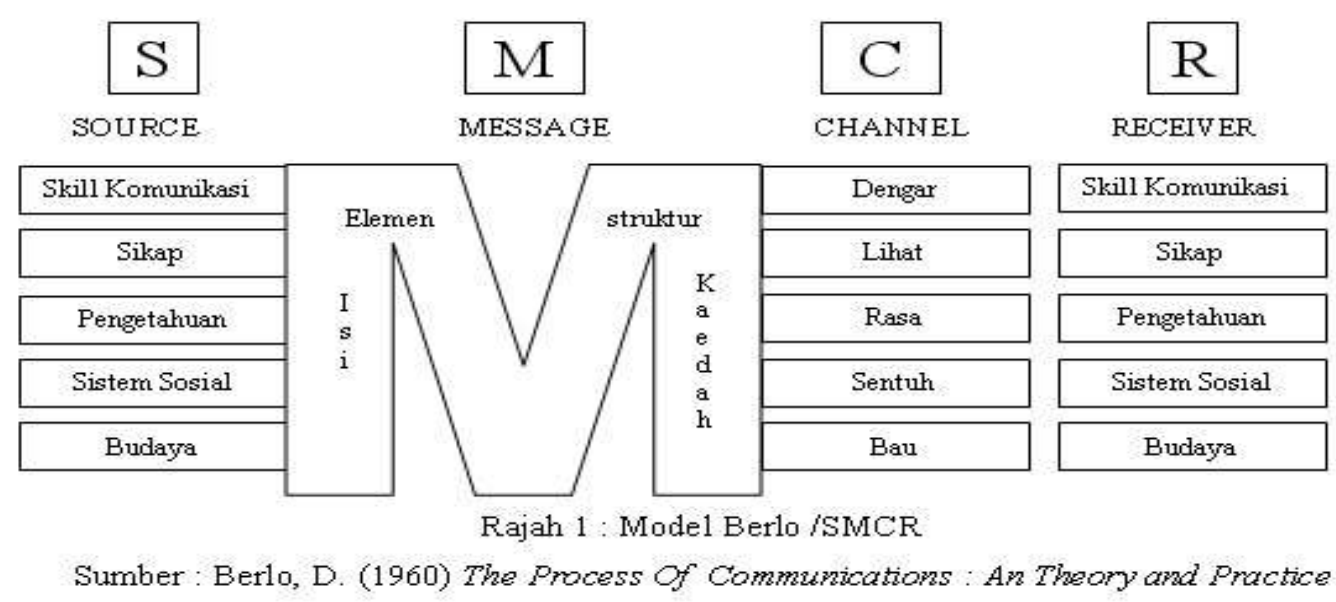

Gambar 10.4: Model Komunukasi Berlo (1960)

Model ini menganggap semua unsur dan pelaku komunikasi sangat menentukan proses komunikasi sampai pada tujuan yang hendak dicapai. Karena itu antara sumber dan penerima mempunyai sarat yang sama agar pesan yang sudah dirancang dengan baik dan tepat dalam pemilihan saluran, dapat menghasilkan komunikasi yang efektif. Berdasarkan model ini, peranan media sebagai saluran adalah penting berdasarkan kata-kata ahli falsafah Kung Fu Tze ada menyatakan 'kalau saya dengar saya lupa, kalau saya lihat saya ingat dan kalau saya buat saya faham'. Dalam konteks yang sama Heinich (1993) menyatakan manusia hafal $10 \%$ melalui penglihatan, $20 \%$ melalui pemahaman dan $30 \%$ melalui pendengaran dan penglihatan. Ini menggambarkan keberkesanan komunikasi bergantung kepada kaedah yang digunakan untuk meransang deria untuk melakukan pemahaman.

\subsection{MODEL S-O-R (STIMULUS ORGANISM RESPON), HOULAND}

Model ini adalah model komunikasi paling dasar. Model ini dipengaruhi oleh disiplin psikologi, khususnya yang beraliran behavioristik. Hal ini bisa terjadi karena psikologi dan komunikasi memiliki objek kajian yang sama, yaitu jiwa manusia; yang meliputi sikap, opini, prilaku, kognisi, afeksi dan konasi. Asumsi dasar teori S-O-R adalah bahwa penyebab terjadinya perubahan prilaku bergantung ada kualitas rangsangan (stimulus) yang berkomunikasi dengan organisme.

Dasar dari pada teori ini adalah adanya asumsi bahwa penyebab terjadinya perubahan perilaku tergantung kepada kualitas rangsang (stimulus) yang berkomunikasi dengan organisme adalah merupakan prinsip-prinsip komunikasi. Adapun istilah-istilah yang digunakan dalam model ini adalah pertama stimulus (S), kedua organism (O) dan ketiga, respons (R). Stimulus yang diberikan kepada organisme dapat diterima atau 
dapat ditolak, maka pada proses selanjutnya terhenti. Untuk memahami lebih jauh, maka kita wajib menyimak penjelasan mengenai teori stimulus respon dalam komunikasi massa.

Komunikasi dianggap sebagai suatu proses aksi-reaksi yang sangat sederhana. Ketika saya tersenyum pada anda dan anda membalas senyuman saya itulah model S-R. Model ini mengasumsikan bahwa kata-kata verbal (lisan - tulisan), isyarat-isyarat non verbal, gambar-gambar, dan tindakan-tindakan tertentu akan merangsang orang lain untuk memberikan respon dengan cara tertentu. Model ini mengabaikan adanya faktor manusia seperti sistem internal individu. Singkatnya model ini menggangap bahwa komunikasi itu bersifat statis. Manusia selalu berperilaku karena adanya stimulus atau rangsangan dari luar, bukan berdasarkan kehendak, keinginan atau kemauan bebasnya. Oleh kareana itu model ini kurang tepat kalau diterapkan pada proses komunikasi manusia.

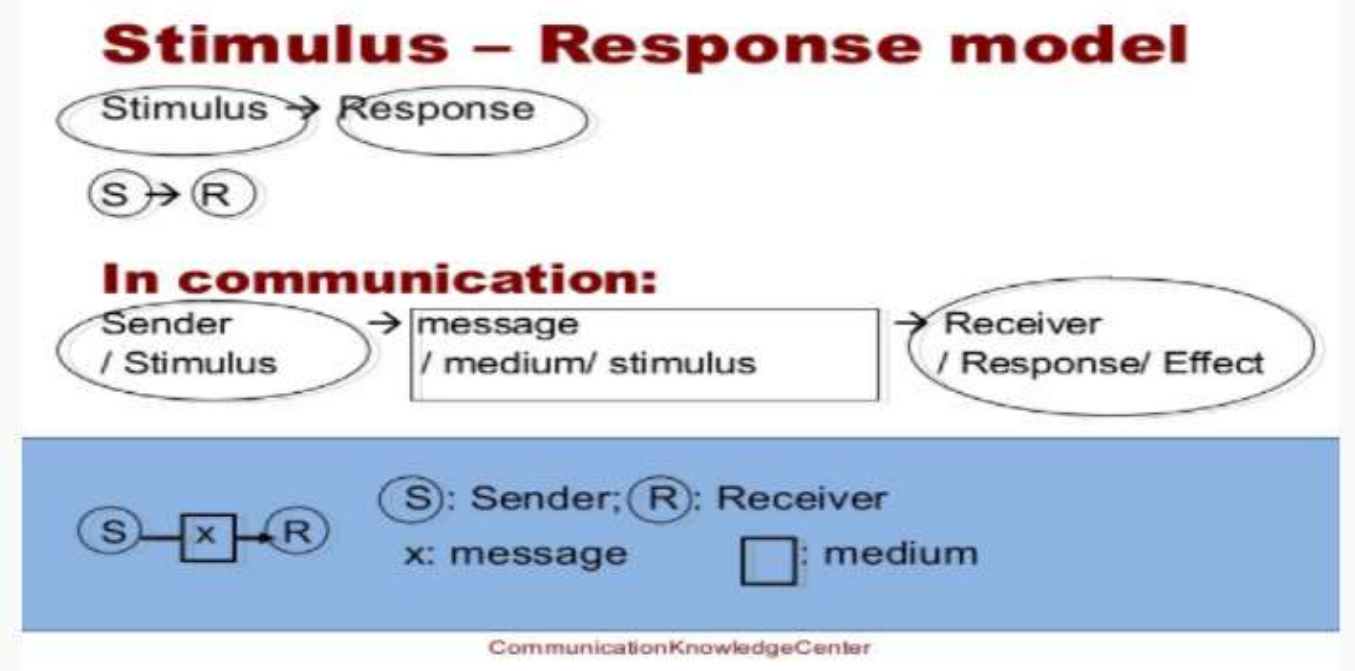

Gambar. 10.5: Model Komunikasi S-R

\subsection{MODEL ARISTOTELES}

Aristoteles adalah filosof yunani, tokoh paling dini yang mengkaji komunikasi, yang intinya komunikasi adalah persuasi. Model Aristoteles adalah model yang paling klasik atau disebut juga model retoris ( Mulyana, 2005:134 ) Oleh karena itu model ini merupakan penggambaran dari komunikasi retoris, komunikasi publik atau pidato. Aristoteles adalah orang pertama yang merumuskan model komunikasi verbal pertama. Proses komunikasi terjadi ketika ada seorang pembicara berbicara kepada orang lain atau khalayak lain dalam rangka merubah sikap mereka. Aristoteles mengemukakan tiga unsur yang harus ada dalam proses komunikasi: 
1. Pembicara (speaker)

2. Pesan (message)

3. Pendengar (listiner)

Sedangkan dalam proses komunikasi persuasive menurut Aristoteles ada tiga factor yang harus dipenuhi: Pertama, Siapa anda (etos kepercayaan anda) Kedua, Apa argumen anda (logos logika dalam pendapat anda) Ketiga, Dan dengan memainkan emosi khalayak (pathos - emosi khalayak).

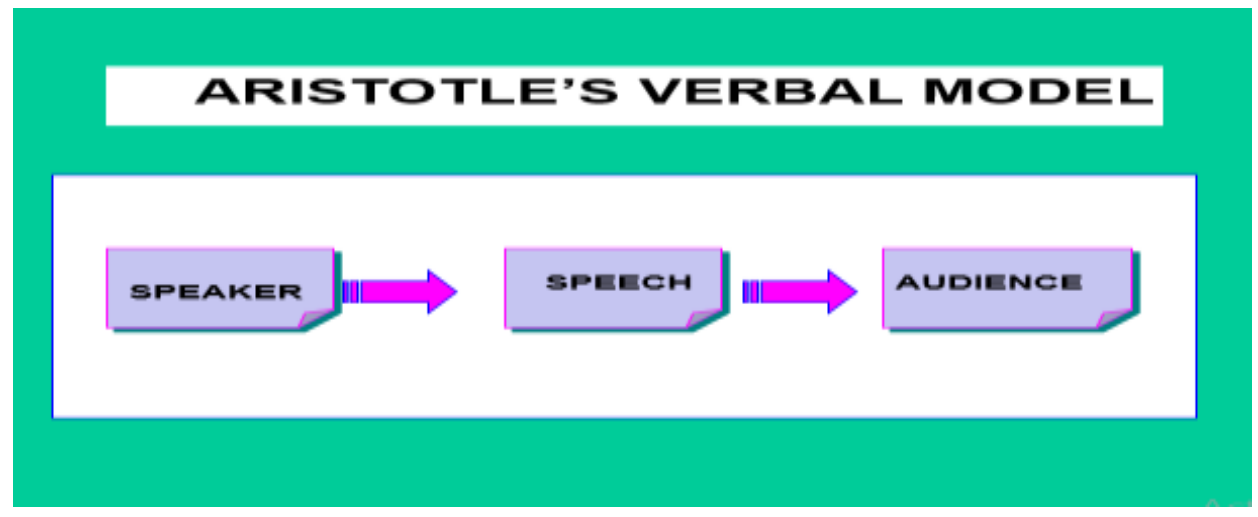

Gambar. 10.6: Model Komunikasi Aristoteles

Salah satu kelemahan model ini adalah bahwa proses komunikasi dipandang sebagai suatu yang statis dan tidak mempedulikan saluran, umpan balik, efek, dan kendala-kendala, di samping itu, model ini juga berfokus pada komunikasi yang disengaja (komunikator mempunyai keinginan secara sadar untuk merubah sikap orang lain).

\subsection{MODEL KOMUNIKASI WILBUR SCHRAMM}

Wilbur Schramm adalah seorang ahli komunikasi yang memberikan pengaruh yang sangat besar dalam memfasilitasi penggunaan model komunikasi linear pada tahun 1950-an dan kemudian bergerak untuk mengembangkan model komunikasi relasional di tahun 1973. Berbagai penelitian komunikasi dan empiris dipengaruhi oleh model komunikasi Schramm. 


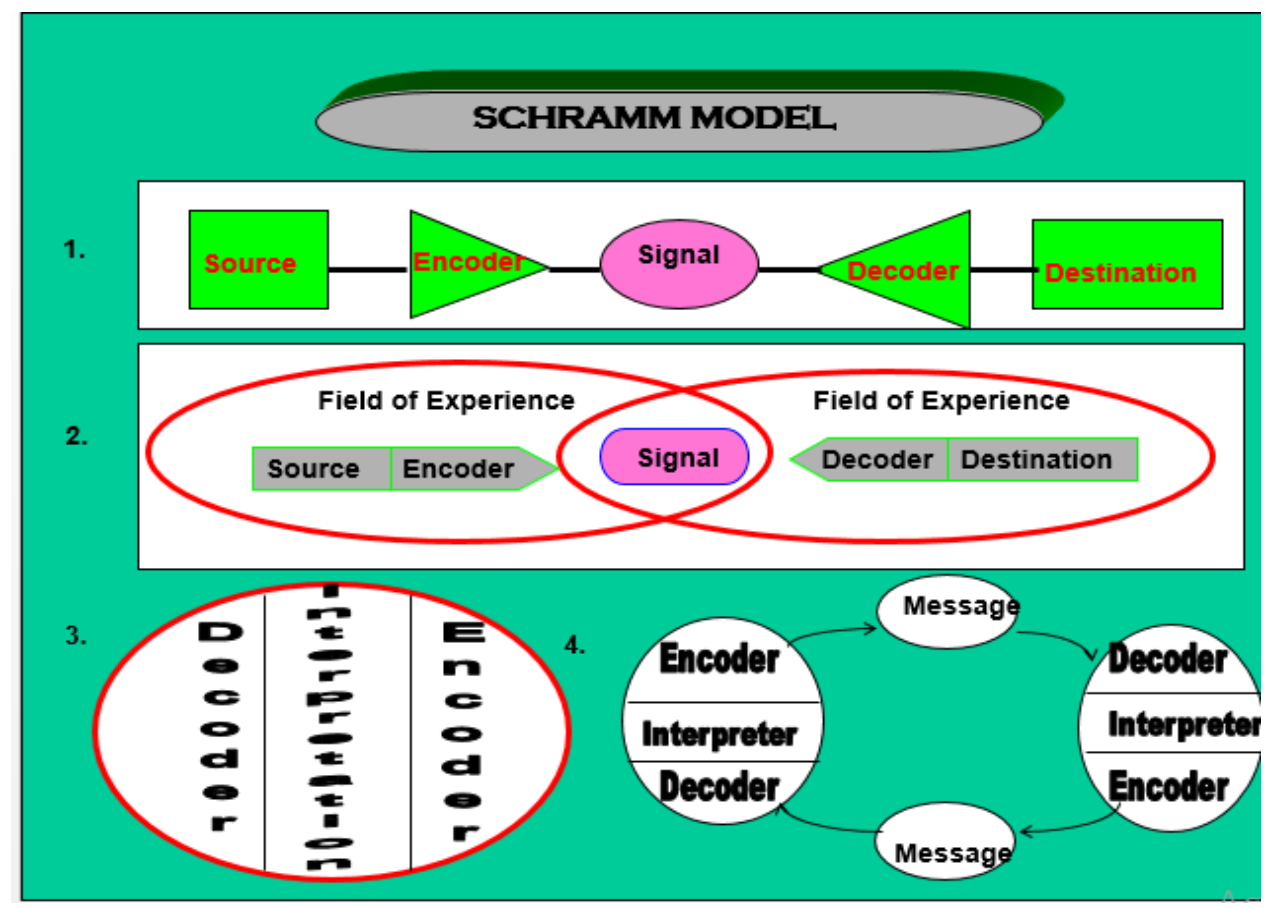

Gambar. 10.6: Model Komunikasi Wilbur Schramm

\section{Model Schram 1.}

Model Schramm 1 masih sangat linier, dimana sumber masih sangat berpengaruh terhadap proses komunikasi. Belum ada interaksi antara sumber dan penerima pesan dalam proses komunikasi. Model ini sama dengan model-model sebelumnya yaitu memperlihatkan proses komunikasi yang satu arah dan tidak dua arah, seseorang individu dapat dipandang sebagai pengirim atau penerima pesan.

\section{Model Schram 1I}

Pada model komunikasi Schramm II pengalaman sumber/komunikator dan pengalaman sasaran/komunikan adalah faktor yang sangat menentukan dalam proses komunikasi. Faktor ini disebut fram of referency atau perpaduan antara pengetahuan dan pengalaman dari komunikator dan komunikan. Artinya pada model Schramm II ini kesamaan fram of referency menentukan dari kelancaran proses komunikasi.

Wilbur Schramm memberikan model proses komunikasi yang agak berbeda sedikit dengan dua model sebelumnya. Dia memperlihatkan pentingnya peran pengalaman dalam proses komunikasi. Bidang pengalaman akan menentukan apakah pesan yang dikirimkan diterima oleh sipenerima sesuai dengan apa yang dimaksud oleh si pengirim pesan. 


\section{Model Schram III \& IV}

Pada model komunikasi Schramm III lebih mengarah pada model komunikasi relasional yang dirumuskan pada tahun 1973, Schramm menekankan pada efek komunikasi terhadap penerima pesan. Schramm menggunakan komponen efek dan analisis efek dari model komunikasi Berlo (1960). Secara implisit Schramm menyarankan sebuah komponen yaitu komponen interaksi ketika ia berbicara tentang khalayak yang aktif, selektif dan manipulatif dalam model komunikasi relasional. Lebih lanjut ia berpendapat bahwa sebagian besar perubahan dramatis dalam teori komunikasi umum dalam kurun waktu lebih dari empat dekade telah mengesampingkan gagasan khalayak yang pasif karena sejatinya dalam proses komunikasi, khalayak adalah mitra seutuhnya bagi komunikator. Model komunikasi ini kemudian dikembangkan menjadi pengirim pesan - pesan - saluran - penerima pesan - efek.

Model proses komunikasi yang digambarkan oleh Osgood \& Schramm sebagai proses sirkular dalam derajat yang tinggi. Komponen-komponen dalam model tersebut adalah sebagai berikut :

a. Encoding (membentuk pesan)

b. Decoding (mengartikan pesan)

c. Interpreting (menginterpretasikan pesan)

d. Message (pesan)

Osgood \& Schramm menitikberatkan pembahasannya pada perilaku utama dalam proses komunikasi. Dan model ini tidak memperhatikan noise (gangguan). Pada model ini sudah ada apa yang disebut dengan Sharing Information. Karena prosesnya sudah bersifat circular terus menerus sehingga setiap pelaku komunikasi bias beralih peran dari komunikator menjadi komunikan begitu sebaliknya dari komunikan menjadi komunikator. Ada dua hal yang penting pada model ini:

Pertama, Sharing Information yaitu informasi yang digunakan bersama oleh peserta komunikasi dalam rangka untuk mencapai pengertian yang sama.

Kedua, Transfer Information yaitu pemahaman sempurna (sama) tentang apa yang dikatakan oleh partisipan satu dengan apa yang diinginkan oleh partisipan lain.

Walau demikian model komunikasi Wilbur Schramm juga tidak luput dari kritik. Beberapa kritik terhadap model komunikasi ini antara lain:

1. Pada kenyataanya tidak mungkin komunikator dan komunikan memiliki field of experience dan frame of reference yang persis sama. Karena dalam konteks komunikasi bisa saja kita menemui kondisi antara komunikator dengan komunikan 
berbeda dalam field of experience dan frame of reference. Kalau kita berpegang pada model ini jelas komunikasi itu tidak akan berjalan. Contoh, bila kita berbicara dengan anak balita yang sudah pasti field of experience dan frame of reference tidak sama dwengan kita tidak mungkin kita memaksakan komunikasi sesuai dengan kemampuan field of experience dan frame of reference kita, melainkan harus menurunkan field of experience dan frame of reference sesuai dengan of experience dan frame of reference anak balita tersebut,karena itu kita kadang berbicara juga seperti anak balita.

2. Schramm tidak memperhitungkan adanya noise yang mungkin saja timbul dalam proses komunikasi.

3. Schramm menyamaratakan kedudukan peserta komunikasi, padahal pada kenyataanya komunikator berkedudukan lebih tinggi disbanding komunikan.

\subsection{MODEL HELICAL DANCE}

Model komunikasi helikal ini dapat dikaji sebagai pengembangan dari model sirkular dari Osgood \& Schramm. Ketika membandingkan model komunikasi linear \& sirkular, Dance mengatakan bahwa dewasa ini kebanyakan orang menganggap bahwa pendekatan sirkular adalah paling tepat dalam menjelaskan proses komunikasi.

Helix, yakni suatu bentuk melingkar yang semakin membesar menunjukkan perhatian kepada suatu fakta bahwa proses komunikasi bergerak maju dan apa yang dikomunikasikan kini akan mempengaruhi struktur dan isi komunikan yang datang menyusul. Dance menggaris bawahi sifat dinamik dari komunikasi.

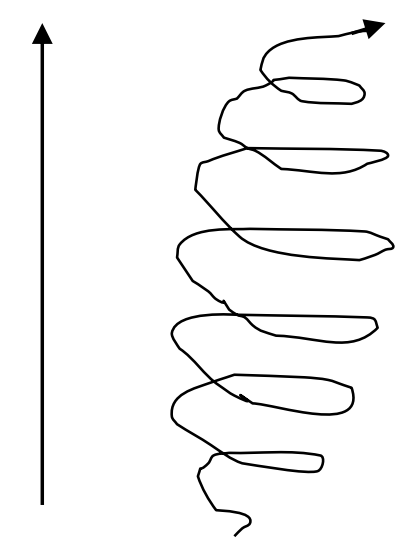

Gambar 10.6. Model komunikasi sirkular dari Osgood \& Schramm 


\subsection{MODEL SEILER}

William J. Seiler ( 1988 ) memberikan model komunikasi dua arah dan bersifat lebih universal. Model tersebut adalah seperti terdapat pada gambar dibawah ini.

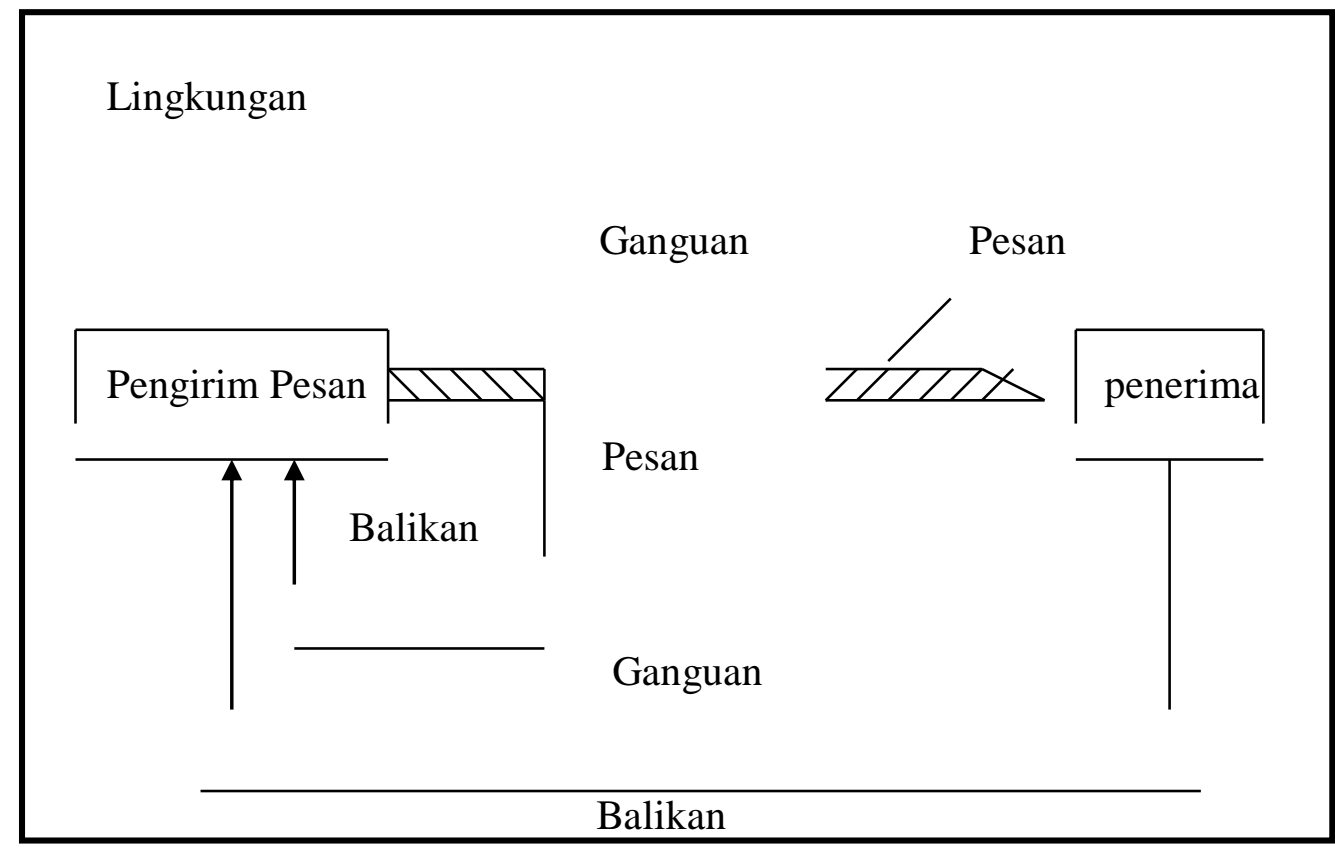

Gambar 10.6. Model komunikasi Dua Arah ( Seiler,1988 )

Menurut Seiler Source atau pengirim pesan mempunyai empat peran yaitu menentuka arti apa yang akan dikomunikasikan, menyandikan arti ke dalam suatu pesan, pengirimkan pesan dan mengamati, dan bereaksi terhadap respons dari penerima pesan.

Pengertian message/pesan adalh sama dengan stimulus yang dihasilkan oleh sumber. Pesan ini mungkin berisi kat-kat, tata bahasa,pengorganisasian, penampilan, gerak badan, kepribadiandll. Model Seiler disamping menekan pentingnya balikan juga menekankan pentingnya faktor lingkungan dalam proses komunikasi.

\section{Referensi}

Yulianita, Modul Pembelajaran Mata Kuliah Pengantar Komunikasi. 2008. Surabaya Mulyana.D. Ilmu Komunikasi Suatu Pengantar. PT REMAJA ROSDAKARYA. Bandung. 2007

Onong Uchjana.E. Ilmu Komunikasi Teori dan Praktek. Remaja Karya. Bandung 1995 Suryanto, Pengantar Ilmu Komunikasi.CV PUSTAKA SETIA. 2015. Sri Moerdijati. Buku Ajar Pengantar Komunikasi. Revka Petra Media 2012 Berger, Roloff, Ewoldsen, Handbook Ilmu Komunikasi. Terjemah, Nusa Media 2014 Vardiansyah. Pengantar Ilmu Komunikasi. Ghalia Indonesia. 2004 John Fiske. Pengantar Ilmu Komunikasi. PT. Raja Grafindo Persada 2012 


\section{BAB XI}

\section{Prinsip-Prinsip Komunikasi}

\section{TUJUAN INSTRUKSIONAL UMUM}

Setelah menyelesaikan materi Bab 10 ini mahasiswa diharapkan mampu:

1. Memahami tentang prinsip-prinsip komunikasi

2. Memahami aplikasi dari prinsip-prinsip komunikasi dalam kehidupan sehari-hari

\section{TUJUAN INSTRUKSIONAL KHUSUS}

Setelah mempelajari materi Bab 10 ini mahasiswa diharapkan mampu:

1. Menjelaskan prinsip-prinsip komunikasi

2. Mendiskusikan tujuan dan aplikasi prinsip-prinsip komunikasi dalam kehidupan sehari-hari

Setiap perilaku mempunyai potensi untuk diartikan sebagai komunikasi, we cannot not communicate. Kita tidak bisa tidak berkomunikasi. Kita selalu berkomunikasi bahkan ketika kita berpikir bahwa kita tidak sedang berkomunikasi atau tidak ingin berkomunikasi. Bahkan diam-pun bisa berarti sesuatu, tetapi ini tidak berarti bahwa semua perilaku adalah komunikasi. Komunikasi baru tercipta ketika seseorang memberi makna pada perilaku orang lain atau perilakunya sendiri. Contoh, seorang mahasiswa duduk paling belakang di kelas dengan wajah tanpa ekspresi dan tatapan kosong. Meskipun mahasiswa tersebut berkata bahwa ia sedang tidak berkomunikasi dengan dosen atau dengan mahasiswa lain tetapi dari perilaku mahasiswa tersebut jelasjelas tersirat bahwa dia tidak tertarik dengan materi di kelas karena itu melamun atau ingin kelas segera mungkin bubar.

Mungkin implikasi terbesar dari prinsip bahwa komunikasi itu adalah hal yang tidak terelakkan adalah bahwa kita perlu sebisa mungkin belajar mengontrol, menggunakan seefektif mungkin segala macam aspek perilaku kita karena segala sesuatu mengenai diri kita itu kita komunikasikan baik kita sadari atau tidak sadari. Tidak hanya kata-kata yang kita ucapkan tetapi juga cara kita berpakaian, cara kita 
berjalan, cara kita mengeluh, cara kita berterima kasih, cara kita melakukan kontak mata atau menghindari kontak mata mengkomunikasikan semuanya.

Jika kita berharap untuk sebisa mungkin memahami orang lain, kita perlu memperhatikan pesan dan makna yang tidak secara jelas dikirimkan oleh mereka seperti pesan yang terkirim dari baju, gerakan tubuh, kontak mata bahkan diam (Devito, 1989:24)

\subsection{KOMUNIKASI MEMPUNYAI DIMENSI ISI DAN HUBUNGAN}

Dimensi isi (verbal), menunjukkan muatan (isi) komunikasi, yaitu apa yang dikatakan.Dimensi hubungan (nonverbal), menunjukkan bagaimana cara mengatakannya yang juga mengisyaratkan bagaimana seharusnya pesan itu ditafsirkan.

Oleh karena itu, isi yang sama bisa bermakna berbeda jika disampaikan dengan cara yang berbeda. Misalnya seorang dosen berkata pada mahasiswanya "temui saya sesudah kelas bubar" dengan "tolong nanti sehabis kuliah kita ketemu di ruang dosen". Isinya sama tetapi dari cara penyampaiannya yang berbeda bisa menghasilkan makna berbeda. Yang pertama mungkin karena diucapkan dengan nada tinggi kita bisa menebak apa yang akan terjadi nanti, mungkin mahasiswa akan kena marah. Dalam komuniaksi massa, pemilihan jenis media adalah dimensi hubungan ( the medium is the message)

Ditinjau dalam konteks komunikasi antarpribadi, dikatakan bahwa secara umum pria lebih fokus pada dimensi isi sedangkan wanita lebih fokus pada dimensi hubungan.

\subsection{KOMUNIKASI ITU BERLANGSUNG DALAM BERBAGAI TINGKAT KESENGAJAAN}

Komunikasi dilakukan dari berbagai tingkat kesengajaan, dari komunikasi yang tidak disengaja sama sekali hingga komunikasi yg benar-benar direncanakan dan disadari. Kesengajaan bukanlah syarat untuk terjadinya komunikasi. Meskipun kita sama sekali tidak bermaksud menyampaikan pesan kepada orang lain, perilaku kita potensial untuk ditafsirkan orang lain. Kita lebih banyak mengeluarkan pesan non verbal yang tdk sengaja dibanding verbal. Kita tidak dapat mengendalikan orang lain untuk menafsirkan atau tidak menafsirkan tindakan kita.

Kadang komunikasi sengaja dibuat tidak sengaja. Misalnya ketika kita menguap sebenarnya menguap lebih pada proses fisik yang terjadi tanpa kita inginkan karena kita mengantuk, tetapi misalnya ketika kita sudah bosan berda di kelas dan merasa bahwa materi yang diberikan dosen tidak menarik maka mahaiswa akan sengaja menguap berkali-kali hingga dosen menyadarinya dan segera mengakhiri perkuliahan. 


\subsection{KOMUNIKASI TERJADI DALAM KONTEKS RUANG DAN WAKTU}

Makna pesan juga bergantung pada konteks fisik/ruang, waktu, sosial dan psikologis. Makna terhadap pesan yang sama belum tentu sama dalam ruang atau waktu yang berlainan. Tertawa terbahahk-bahak, atau memakai pakaian warna merah sebagai perilaku nonverbal yang tidak menjadi masalah jika kita berada dalam suatu pesta, tetapi akan menjadi sangat tidak pantas apabila kita berada dalam situasi pemakaman. atau Teriak2 dalam mendukung kesebelasan yang sedang bertanding >> sehat. Tapi kalau sedang sendirian dan di jalanan ???

\subsection{KOMUNIKASI MELIBATKAN PREDIKSI PESERTA KOMUNIKASI}

Ketika individu berkomunikasi mereka meramalkan efek komunikasi mereka. Dengan kata lain komunikasi juga terikat aturan atau tata krama. Kita dapat memprediksi perilaku komunikasi orang lain berdasarkan peran sosialnya, misalnya kita tahu bagaimana tatakrama dalam berbahasa ketika berbicara dengan orang tua atau dosen kita. Komunikasi terikat oleh aturan atau etika. Prediksi tidak selalu disadari dan sering berlangsung cepat. Hingga derajat tertentu ada keteraturan perilaku manusia sehingga bisa diprediksi.

\subsection{KOMUNIKASI ITU BERSIFAT SISTEMIK}

Ada dua sistem dasar dalam transaksi komunikasi:

a. Sistem Internal adalah seluruh sistem nilai yang dibawa oleh seorang individu ketika ia memasuki suatu situasi komunikasi Sistem Internal mengandung semua unsur yang membentuk individu yang unik (kepribadian, intelegensia, pengetahuan, agama, dll) yang pada dasarnya tersembunyi.-frame of reference $\&$ field of experience.

b. Sistem Eksternal terdiri dari unsur-unsur dalam lingkungan di luar individu, termasuk kata-kata yangdi pilih dalam berkomunikasi, isyarat fisik peserta komunikasi, kegaduhan di sekiatarnya, penataan ruangan, cahaya dan temperatur ruangan.

Semakin mirip latar belakang sosial budaya, maka semakin efektif pula proses komunikasi yang berlangsung. Komunikasi yang efektif adalah komunikasi yang hasilnya sesuai dengan harapan para pesertanya (pihak yang melakukan komunikasi). Adanya latar belakang yang sama diantara para pelaku komunikasi membuat suatu situasi komunikasi lebih berpotensi untuk mencapai keefektifan.

Kenyataannya, tidak pernah ada individu yang sama persis. Bahkan anak yang kembar identik dan dibesarkan di tempat yang sama-pun tidak akan mempunyai state of 
mind yang sama persis. Namun kesamaan dalam hal-hal tertentu seperti umur, suku, bahasa, tingkat pendidikan akan mendorong suatu proses komunikasi berlangsung lebih efektif.

\subsection{KOMUNIKASI BERSIFAT NONSEKUENSIAL}

Kebanyakan situasi komunikasi bersifat dua arah. Meskipun ada model komunikasi linear atau satu arah tetapi pada akhirnya komunikasi tersebut akan bersifat dua arah, karena pada akhirnya suatu situasi komunikasi akan menimbulkan adanya umpan balik. Oleh karena itu peran komunikator dan komunikan dalam suatu percakapan 2 individu atau lebih tidak melekat dan terus berganti. Sehingga sudah tidak bisa dibedakan lagi antara pesan dan umpan balik.

\section{7.'KOMUNIKASI BERSIFAT PROSESUAL, DINAMIS DAN TRANSAKSIONAL}

Suatu proses komunikasi adalah proses yang berkesinambungan, tidak mempunyai awal dan tidak mempunyai akhir. Komunikasi itu melibatkan sebuah proses penyesuaian karena itu komunikasi sifatnya dinamis bukan stabil.Komunikasi bersifat transaksional karena pada saat hampir bersamaan kita melakukan encoding dan decoding, pada saat hampir bersamaan kita itu mengirim dan menerima pesan.Implikasi dari komunikasi sebagai proses yang dinamis dan transaksional adalah bahwa para peserta komunikasi berubah (dari sekedar pengetahuan hingga perubahan dalam memandang dunia yang akhirnya mengarah pada perubahan perilaku)

\subsection{KOMUNIKASI BERSIFAT IRREVERSIBLE}

Beberapa sistem itu sifatnya dapat ditarik atau diulang kembali, seperti ketika kita mendinginkan air pada suhu tertentu hingga berubah menjadi es lalu kita mengulangnya kembali dengan merubah es kembali menjadi air. Tetapi ada sistem yang sifatnya irreversible prosesnya hanya bergerak menuju satu arah tidak dapat ditarik kembali menuju ke arah sebelumnya, dan komunikasi termasuk sistem ini. Komunikasi adalah suatu proses yang tidak bisa ditarik kembali. Tindakan komunikasi yang telah kita lakukan adalah telah terjadi dan tidak mungkin ditarik kembali. Sekali kita mengirimkan suatu pesan, kita tidak dapat mengendalikan pengaruh pesan tersebut bagi khalayak, apalagi menghilangkan efek pesan tersebut sama sekali. Menurut Devito (1989:25) bahkan karena sifat irreversible-nya kita perlu waktu untuk mempertahankan atau membenarkan perilaku kita yang diterima orang lain secara negatif. Metode paling 
umum yang kita gunakan untuk menghadapi reaksi negatif dari individu lain terhadap perilaku kita adalah dengan melakukan excuse atau beralasan (berusaha melakukan pembenaran terhadap perilaku yang "sudah" terlanjur kita lakukan dan ternyata mendapat reaksi negatif dari individu lain).

Sifat irreversible ini adalah implikasi dari komunikasi sebagai suatu proses yang selalu berubah. Prinsip ini setidaknya menyadarkan kita bahwa kita harus berhati-hati dalam mengirimkan suatu pesan kepada orang lain karena efeknya tidak bisa ditiadakan sama sekali meskipunkita sudah berusaha meralatnya. To forgive but not to forget kalau kata orang inggris.

\subsection{KOMUNIKASI BUKAN PANASEA UNTUK MENYELESAIKAN BERBAGAI MASALAH}

Banyak persoalan dan konflik antarmanusia disebabkan oleh masalah komunikasi. Namun komunikasi itu sendiri bukanlah obat mujarab (panasea) untuk menyelesaikan persoalan atau konflik itu, karena persoalan atau konflik tersebut mungkin berkaitan dengan masalah struktural. Esensi dari konflik harus tetap dicari dan diselesaikan. Misalnya konflik antara GAM dan pemerintah tidak akan pernah selesai walaupun pemerintah sudah berusaha melakukan komunikasi seefektif mungkin apabila pemerintah tidak memenuhi janjinya untuk mensejahterakan rakyat di daerah tetapi terus menerus hanya mengeruk kekayaan daerah guna memperkaya pusat.

\section{Referensi}

Mulyana.D. Ilmu Komunikasi Suatu Pengantar. PT REMAJA ROSDAKARYA. Bandung. 2007

DevitoA.Joseph. Komunikasi antar manusia, edisi kelima terjemah Hunter College of the city University of New York

McQuail's. Mass Communication Theory.Salemba Humanika. 2011

Elvinaro dan Lukiati. Komunikasi Massa Suatu Pengantar. Sembiosa Rekatama Media. 2004

Rakhmat, Jalaluddin. 2009. Psikologi Komunikasi Edisi Revisi. Bandung: Remaja Rosdakarya

Cangara, Hafied. Pengantar Ilmu Komunikasi, PT Raja Grafindo Persada. Jakarta. 2004

Devito, Joseph A. Komunikasi Antar Manusia edisi ke-5, Professional Books. 1997

Sasa Djuarsa S., Teori Komunikasi, Universitas Terbuka, Jakarta. 2003

John Fiske, Introduction to Communication Studies, Sage Publications, 1996

Stephen W. Littlejohn, Theories of Human Communiation, Wadsworth Publication, New Jersey, 1996. 
Brent D. Ruben, Communication and Human Behaviour, Prentice Hall, New Jersey, 2004

Effendi, Onong Uchjana. 1993. Ilmu, Teori \& Filsafat Komunikasi. Bandung: Citra Aditya Bakti.

Blake, R.H, dan Haroldsen, E.O. 2005. Taksonomi Konsep Komunikasi. Surabaya: Papyrus.

Berger, Roloff, Ewoldsen, Handbook Ilmu Komunikasi. Terjemah, Nusa Media 2014

Vardiansyah. Pengantar Ilmu Komunikasi. Ghalia Indonesia. 2004

\section{Profile Penulis}

Dr. Didik Hariyanto., S.Sos., M.Si, lahir di Situbondo 12 Desember 1973. Menyelesaikan Program Sarjana (S1) Ilmu Komunikasi tahun 1998 di Umsida, Program Magister (S2) Ilmu Komunikasi tahun 2008 di UNITOMO Surabaya, Program Doktoral (S3) Ilmu Sosial tahun 2018 Universitas Airlannga Surabaya. Sejak tahun 1999 penulis sudah menjadi dosen di Program Studi Ilmu Komunikasi Umsida. Beberapa posisi yang pernah diamanatkan kepada penulis diantaranya sebagai Ketua Program Studi Administrasi Negara, Ketua Program Studi Ilmu Komunikasi, Ketua HKI Umsida, Wakil Dekan Fakultas Bisnis, Hukum dan Ilmu Sosial. Penulis juga sebagai pengajar tamu dibeberapa perguruan tinggi swasta.

Penulis aktif di organisasi Asosiasi Perguruan Tinggi Ilmu Komunikasi Perguruan Tinggi Muhammadiyah se Indonesia. Juga aktif di Asosiasi Perguruan Tinggi ilmu Komunikasi (ASPIKOM) Korwil Jawa Timur. Beberapa karya ilmiah penulis sudah terindeks dalam jurnal nasional terakreditasi Sinta dan beriputasi. Penulis juga aktif dalam seminar nasional dan internasional baik sebagai peserta maupun narasumber. 
ISBN 978-623-6081-32-7 (PDF)

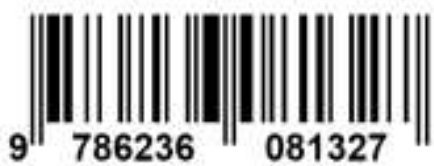

